\title{
A FISHERIES EVALUATION OF THE WAPATO, SUNNYSIDE, AND TOPPENISH CREEK CANAL \\ FISH SCREENING FACILITIES \\ SPRING 1988
}

\section{Annual Report}

\author{
By \\ Duane A. Neitzel \\ C. Scott Abernethy \\ E. William Lusty \\ Pacific Northwest Laboratory
}

\author{
Prepared For \\ Thomas Clune, Project Manager \\ U.S. Department of Energy \\ Bonneville Power Administration \\ 103 South 3rd Street \\ Yakima. Washington 98901 \\ Project No. 85-62 \\ Contract No. DE-ACO6-76RLO 1830
}

March 1990 
The Bonneville Power Administration, the United States Bureau of Reclamation, and the Washington State Department of Ecology are funding the construction and evaluation of fish passage and protection facilities at irrigation and hydroelectric diversions in the Yakima River Basin. Washington State. This construction implements Section $903 \mathrm{~s}$ (d) and 803 (b) of the Northwest Power Planning Council's 1984 and 1987 Columbia River Basin Fish and Wildife Programs. (a) The programs provide offsite enhancement to compensate for fish and wildlife losses caused by hydroelectric development throughout the Columbia River Basin and address natural propagation of salmon to help initigate the impact of irrigation in the Yakima River Basin.

The Wapato. Sunnyside, and Toppenish Creek Screens are three of the facilities in the basin. This report evaluates the effectiveness of the screens in intercepting and returning juvenile salmonids unharmed to the river from which they were diverted. Fish were released upstream of or within the screen facilities and captured in the diversion that transfers them back to the river. The screens safely divert fish from the canals to the river. Test fish were steelhead Oncorhynchus mykiss smolts: spring chinook salmon 0 . tshawytscha smolts: and fall chinook salmon fry. Evaluations were conducted during typical spring flows.

(a) NPPC (Northwest Power Planning Council). 1984. Celumbia Biver Basin Eish and Wild life Program. Northwest Power Planning Council. Portland, Oregon. NPPC (Northwest Power Plarning Council). 1987. Columbia Biver Basin Eish and Wild ife Program. Northwest Power Planning Council. Portland. Oregon. 


\section{ACKNOWLEDGMENTS}

The involvement and cooperation of many people were greatly appreciated. Thomas J. Clune, Bonneville Power Administration. was the Project Manager. Chuck Keller and Ed Spegler. Bureau of Reclamation, and their operations and maintenance staffs provided critical support and assistance during site preparation and data collection. Dan 0lney. White Swan. Washington. helped at the Toppenish Creek site. Mark Schuck. Washington Department of Wildlife, and Bill James. Washington Department of Fisheries, helped procure test fish. Tom Scribner. Yakima Indian Nation, helped coordinate the fall chinook salmon releases from the Wapato net pens during our screen integrity tests at the Wapato and Sunnyside facilities. Sally J. Wampler and Jeanne $C$. Simpson did the statistical analysis. Robert $H$. Gray and Andy Plymale reviewed the manuscript. 
We evaluated the effectiveness of new screening facilities at the Toppenish Creek. Wapato, and Sunnyside canals in southcentral Washington State.

screen integrity tests indicated that fish released in front of the screens were prevented from entering the canal behind the screens. Screen efficiency estimates are $99 \%( \pm 0.6 \%)$ for Toppenish Creek, $99 \%( \pm 0.3 \%)$ for Wapato, and $98 \%( \pm 0.5 \%)$ for Sunnyside. During 1987 at the Wapato Canal, we estimated screen efficiency was $97 \%( \pm 1 \%)$.

We conducted descaling tests at the Toppenish Creek Screens. We estimated that $0.2 \%$ oi steelhead Oncorhynchus mykiss smolts released during tests were descaled. None of the fish released through the fish return pipe were descaled.

We measured the time required for fish to move through the screen facilities. The time required for $50 \%$ of the test fish to exit the Toppenish Creek screen forebay was 4 to $9 \mathrm{~h}$ for rainbow trout fry and up to $39 \mathrm{~h}$ for steelhead smolts. The time for $50 \%$ of the test fish to exit the Wapato and Sunnyside screen forebays was less than $8 \mathrm{~h}$. As with past studies, exit times varied with canal flow and species. After $39 \mathrm{~h}$ at Toppenish Creek, half the steelhead smolts were still in the forebay when canal flows were $20 \mathrm{cfs}$. At Sunnyside, half the chinook salmon fry exited the forebay in $1 \mathrm{~h}$ or less.

Methods used in 1988 were the same as those used at Sunnyside in 1985 and in subsequent years at Richland. Toppenish/Satus, and Wapato. The methods and previous results have been reviewed by the Washington State Department of Fisheries, U.S. Fish and Wild ife Service. National Marine Fisheries Service. Northwest Power Planning Council, and Yakima Indian Nation. 


\section{CONTENTS}

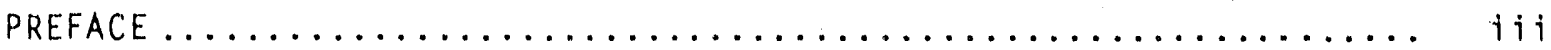

ACKNOWLEDGMENTS $\ldots \ldots \ldots \ldots \ldots \ldots \ldots \ldots \ldots \ldots \ldots \ldots \ldots \ldots$

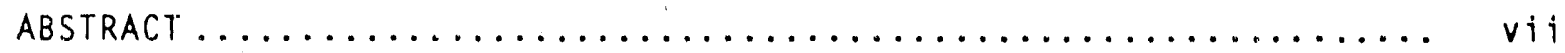

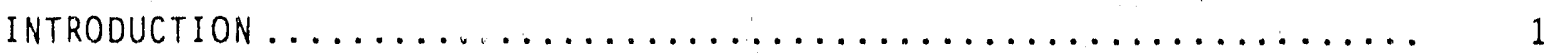

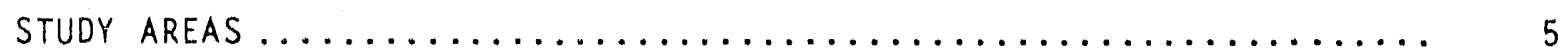

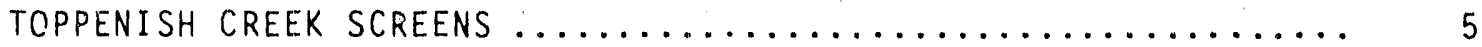

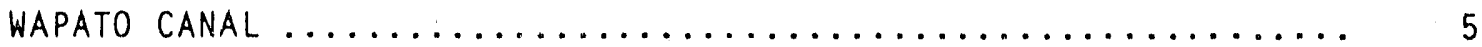

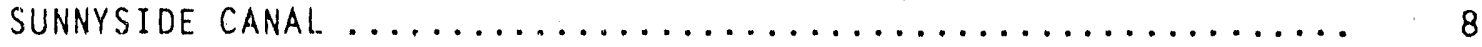

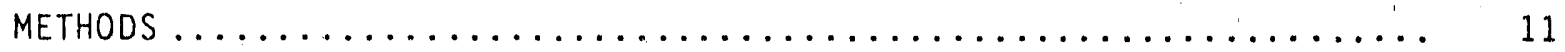

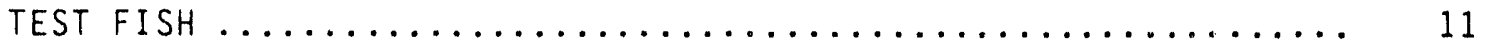

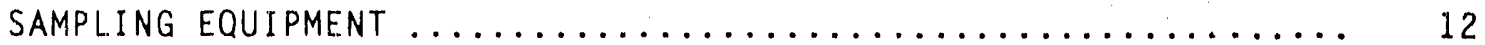

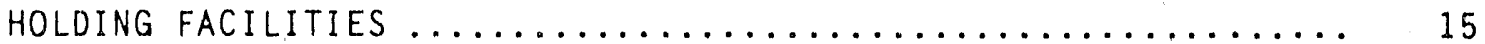

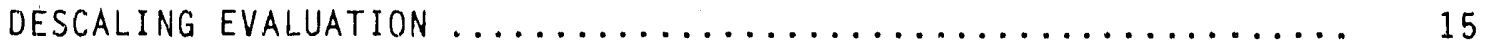

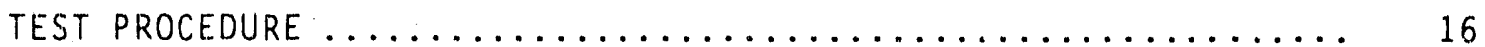

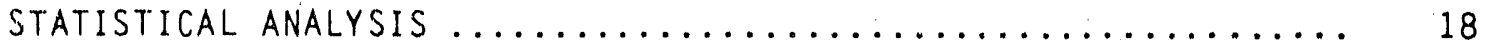

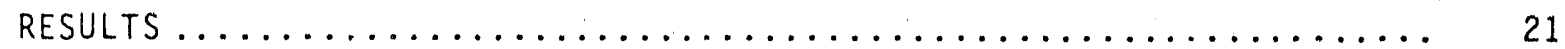

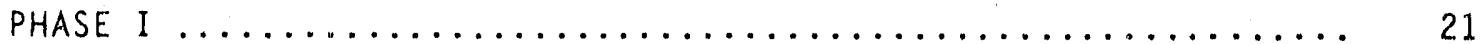

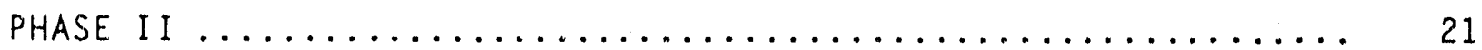

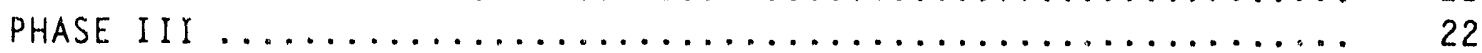

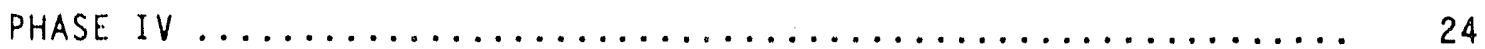

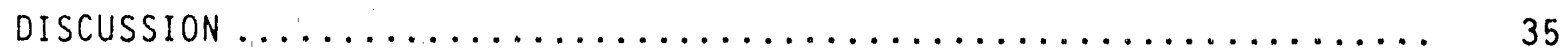

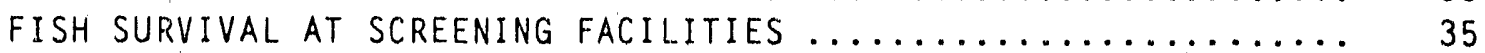

POTENTIAL FOR PREDATION AT SCREENING FACILITIES ............ 35

POTENTIAL FOR FISH DELAY AT SCREENING FACILITIES ........... 37

FISH PASSAGE THROUGH OR OVER ROTARY DRUM SCREENS .......... 37

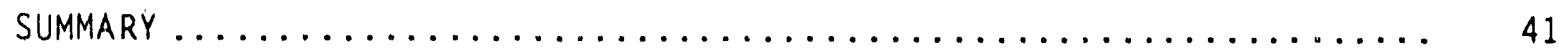

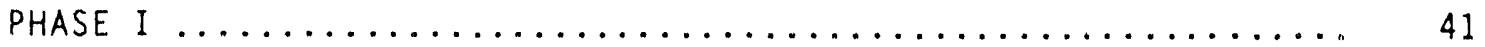

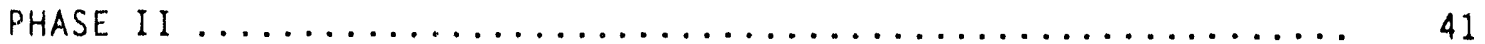

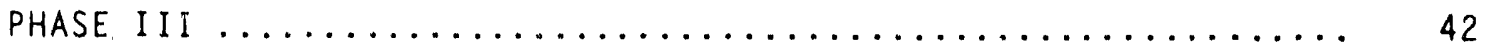

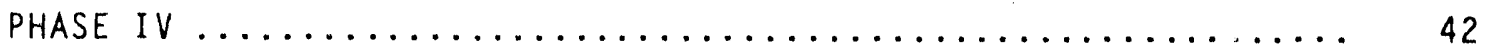

RECOMMENDATIONS ............................ 43

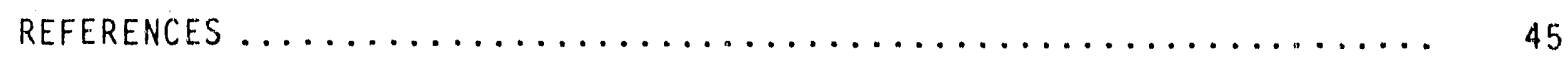

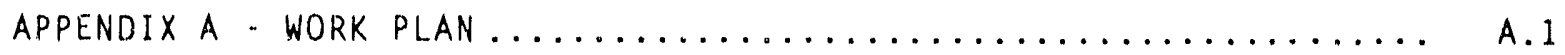


APPENDIX B - RELEASE AND CAPTURE DATA FROM SUNNYSIDE, RICHLAND, TOPPENISH/SATUS, WAPATO, AND TOPPENISH CREEK CANAL FISH

SCREENING FACILITIES ....................

B. 1

APPENDIX C - OPERATING CRITERIA FOR FISH SCREENING FACILITIES

AT SUNNYSIDE, WAPATO, AND TOPPENISH CREEK .......... C.1 


\section{EIGURES}

1. Yakima River Basin Showing Locations of the Toppenish Creek. Wapato, and Sunnyside Canal Fish Screening Facilities and Other

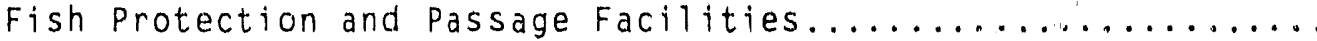

2. Toppenish Creek, Wapato, and Sunnyside Canal Fish Screening Facilities in the Yakima River Basin.....................

3. Flow Control Structure and Fish Bypass System in the Toppenish

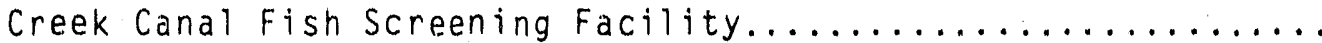

4. Flow Control Structure and Fish Bypass system in the Wapato

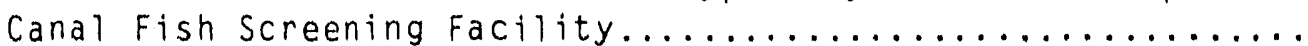

5. Flow Control Structure and Fish Bypass System in the Sunnyside

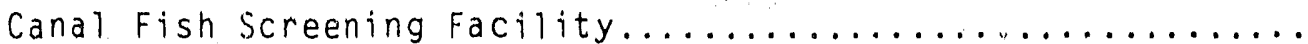

6. Inclined Plane Used at the Toppenish Creek Canal Fish Screening

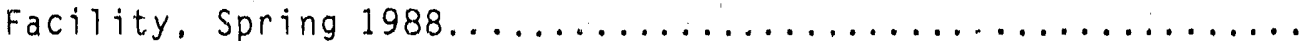

7. Fyke Nets Used in Integrity Tests at the Sunnyside Screens,

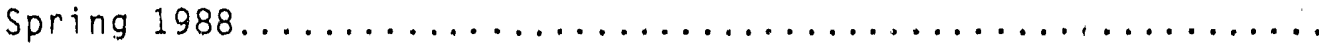

8. Movement of Steelhead Oncorhynchus mykiss Smolts Based on Capture of Released Fish at the Toppenish Creek Canal Fish Screening Facility, Spring 1988.

9. Movement of Rainbow Trout Oncorhynchus mykiss Fry Based on Capture of Released Fish in the Bypass During Screen Integrity Tests at the Toppenish Creek Canal Fish Screening Facility,

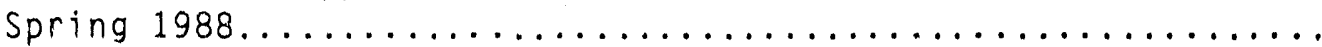

10. Movement of Fall Chinook Salmon Oncorhynchus tshawytscha Fry Based on Capture of Released Fish in the Bypass During Screen Integrity Tests at the Wapato Canal Fish Screening Facility.

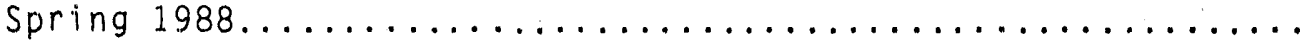

11. Movement of Fall Chinook Salmon Oncorhynchus tshawytscha Fry Based on Capture of Released Fish in the Bypass During Screen Integrity Tests at the Sunnyside Canal Fish Screening Facility. Spring 1988. 


\section{IABLES}

1. Descaling and Mortality Data from Release and Capture Tests with Steelhead Oncorhynchus mykiss Smolts at the Toppenish Creek Fish Screening Facility. Spring $1988 . \ldots \ldots \ldots \ldots \ldots \ldots$

2. Estimated Time to Capture $50 \%$ of Steelhead Oncorhynchus mykiss Smolts Released in Descaling Tests at Toppenish

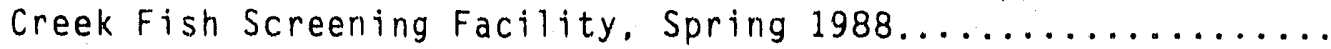

3. Capture Data for Rainbow Trout Oncorhynchus mykiss Fry Released During Screen Integrity Tests at the Toppenish

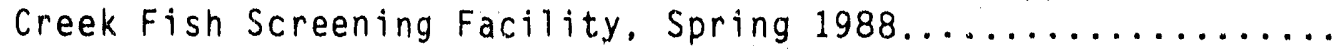

4. Capture Efficiency of the Inclined Plane and Fyke Nets Used During Screen Integrity Tests at the Toppenish Creek Fish

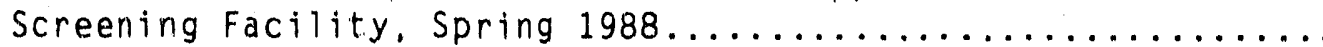

5. Estimated Time to Capture $50 \%$ of Rainbow Trout Oncorhynchus mykiss Fry Released in Screen Integrity Tests at Toppenish Creek Fish Screening Facility, Spring 1988................

6. Capture Data for Fall Chinook Salmon Oncorhynchus tshawytscha Fry Released During Screen Integrity Tests at the Wapato Canal Fish Screening Facility. Spring $1988 \ldots \ldots \ldots \ldots \ldots \ldots$

7. Capture Efficiency of Inclined Plane and Nets and Retention Efficiency for Fyke Nets Used During Screen Integrity Tests at the Wapato Canal Fish Screening Facility, Spring 1988......

8. Estimated Time to Capture $50 \%$ of Fall Chinook Salmon Oncorhynchus tshawytscha Fry Released in Screen Integrity Tests at the Wapato Fish Screening Facility, Spring 1988......

9. Capture Data from Fyke Nets Behind Selected Screens at the Wapato Canal Fish Screening Facility After Release of Yakima Indian Nation Fall Chinook Salmon Oncorhynchus tshawytscha from Net Pens in the wapato Screen Forebay.

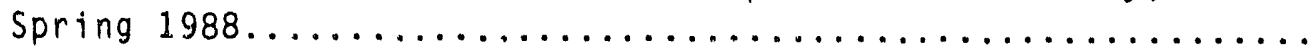

10. Capture Data for Fall Chinook Salmon Oncorhynchus tshawytscha Fry Released During Screen Integrity Tests at the Sunnyside Fish Screening Facility. Spring $1988 \ldots \ldots \ldots \ldots \ldots \ldots \ldots \ldots \ldots \ldots$

11. Capture Efficiency of the Inclined Plane and Fyke Nets During Integrity Tests at the Sunnyside Canal Fish

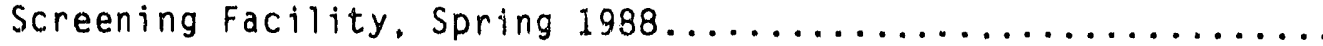


12. Estimated Time to Capture $50 \%$ of Fall Chinook Salmon Oncorhynchus tshawytscha Fry Released in Integrity Tests at the Sunnyside Fish Screening Facility, Spring $1988 \ldots . . . \ldots$.

13. Capture Data from Fyke Nets Behind Selected Screens at the Sunnyside Canal Fish Screening Facility After Release of Yakima Indian Nation Fall Chinook Salmon Fingerlings oncorhynchus tshawytscha Fingerlings from the Wapato

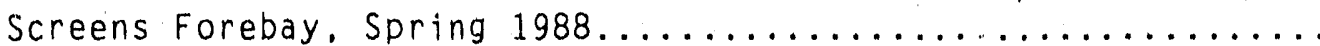

14. Capture Efficiency During Screen Efficiency Testis at the Wapato Canal Fish Screening Facility. Spring 1987 and $1988 . .$. .

B.1 Percentage of Coho Salmon Oncorhynchus kisutch Smolts Descaled or Killed During Tests of the Inclined Plane at Sunnyside Canal Fish Screening Facility, Spring 1985 ......

B.2 Percentage of Steelhead Oncorhynchus mykiss and Chinook Salmon 0 . tshawytscha Smolts Descaled or Killed During Tests of the Fyke Net at Sunnyside Canal Fish Screening

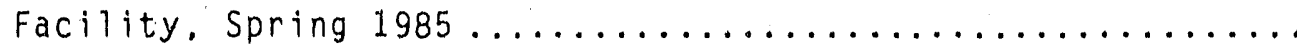

B.3 Percentage of Steelhead Oncorhynchus mykiss Smolts Descaled Before Being Used in Tests at Sunnyside Canal Fish Screening

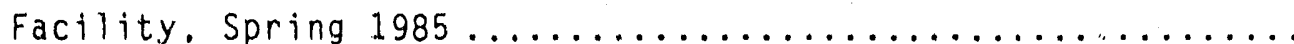

B.4 Percentage of Chinook Salmon Oncorhynchus tshawytscha Smolts Descaled Before Being Used in Tests at Sunnyside Canal Fish

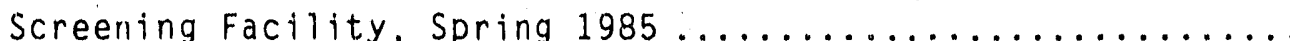

B.5 Percentage of Steelhead Oncorhynchus mykiss Smolts Descaled or Killed in Each Test at Sunnyside Canal Fish Screening

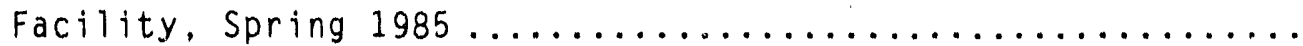

B.6 Percentage of Chinook Salmon Oncorhynchus tshawytscha Smolts Descaled or Killed in Each Test at Sunnyside Canal Fish

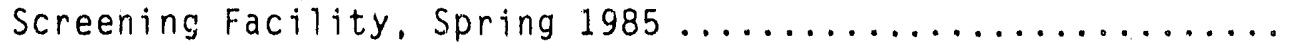

B.7 Scale Loss for Hatchery-Released and Native Fish Captured During Tests at Sunnyside Canal Fish Screening Facility.

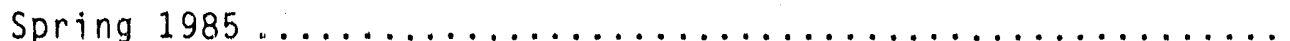

B.8 Percentage of Chinook Salmon Oncorhynchus tshawytscha Smolts Descaled or Killed During Tests of the Inclined Plane at Richland Canal Fish Screening Facility, Spring $1986 \ldots . . . . .$.

B.9 Percentage of Chinook Salmon Oncorhynchus tshawytscha Smolts Descaled or killed During Tests of the Fyke Net at Richland Canal Fish Screening Facility, Spring $1986 \ldots \ldots \ldots \ldots \ldots \ldots$ 
B.10 Percentage of Steelhead Oncorhynchus mykiss Smolts Descaled Before Being Used in Tests at Richland Canal Fish Screening

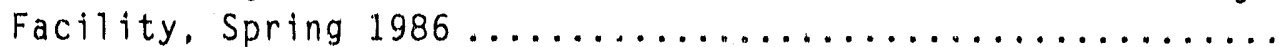

B.11 Percentage of Chinook Salmon Oncorhynchus tshawytscha Smolts Descaled Before Being Used in Tests at Richland Canal Fish

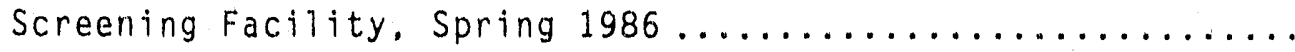

B.12 Descaling and Mortality Data from Release and Capture Tests with Steelhead Oncorhynchus mykiss Smolts at Richland Canal Fish Screening Facility. Spring 1986

B.13 Descaling and Mortality Data from Release and Capture Tests with Spring Chinook Salmon Oncorhynchus tshawytscha Smolts at Richland Canal Fish Screening Facility. Spring 1986 .......

B.14 Estimated Time to Catch $50 \%$ and $95 \%$ of Test Fish Captured at Richland Canal Fish Screening Facility. Spring 1986

B.15 Scale Loss for Hatchery-Released and Native Fish Captured During Tests at Richland Canal Fish Screening Facility.

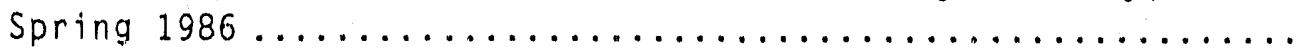

B.16 Percentage of Steelhead Oncorhynchus mykiss Smolts Descaled Before Being Used in Tests at Toppenish/Satus Canal Fish

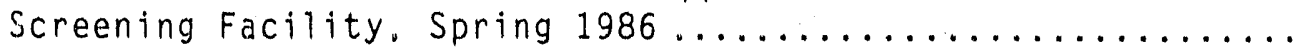

8.17 Descaling and Mortality Data from Release and Capture Tests with Steelhead Oncorhynchus mykiss Smolts at Toppenish/Satus Canal Fish Screening Facility, Spring $1986 \ldots \ldots \ldots \ldots \ldots \ldots \ldots$

B.18 Estimated Time to Catch $50 \%$ and $95 \%$ of Test Fish Captured at Toppenish/Satus Canal Fish Screening Facility. Spring 1986 .

B.19 Scalé Loss for Hatchery-Reared and Nature Fish Captured During Tests at Toppenish/Satus Canal Fish Screening Facility, Spring 1986

B.20 Percentage of Spring. Chinook Salmon Oncorhynchus tshawytscha and Steelhead 0 . mykiss Smolts Descaled or killed During Tests of the Inclined Plane at Wapato Caral Fish Screening

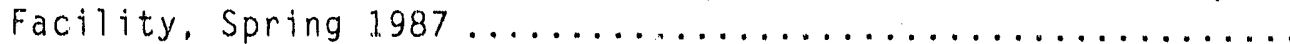

B.21 Percentage of Steelhead Oncorhynchus mykiss Smolts That Were Descaied Before Being Used in Tests at Wapato Canal Fish Sureening racility. Spring 1987 
B.22 Percentage of Spring Chinook Salmon Oncorhynchus tshawytscha

Smolts That Were Descaled Before Being Used in Tests at

Wapato Canal Fish Screening Facility, Spring $1987 \ldots \ldots \ldots \ldots$. .

B. 14

B.23 Percentage of Steelhead Smolts Oncorhynchus mykiss Descaled or Killed in Each Test at Wapato Canal Fish Screening

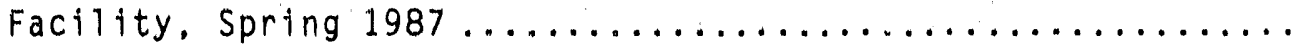

B.24 Percentage of Spring Chinook Salmon Smolts Oncorhynchus tshawytscha Descaled or Killed in Each Test at Wapato Canal Fish Screening Facility, Spring 1987

B.25 Scale Loss for Hatchery-Released and Native Salmonids Cartured During Tests at Richland Canal Fish Screening Facility, Spring 1987

B.26 Scale Loss for Hatchery-Released and Native Salmonids Captured During Tests at the Wapato Canal Fish Screening

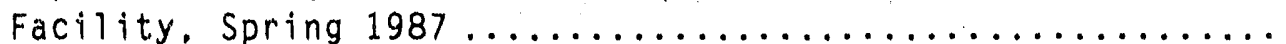

B.27 Percentage of Test Fish Descaled or Killed During Pipe Tests at Wapato Canal Fish Screening Facility. Spring

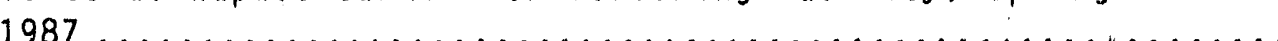

B.28 Estimated Time to Capture $50 \%$ and $95 \%$ of the Test Fish Released at Wapato Canal Fish Screening Facility, Spring 1987

B.29 Capture Data for Fall Chinook Salmon Fry Oncorhynchus tshawytscha Released at Richland Canal Fish Screening Facility, Spring 1987

B.30 Capture Efficiencies of the Inclined Plane and Nets and Retention Efficiency of the Fyke Nets Used in Screen Integrity Tests at Wapato Canal Fish Screening Facility.

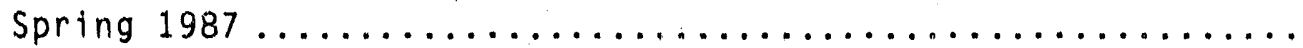

B.31 Capture Data for Fall Chinook Salmon Fry Oncorhynchus tshawytscha Released During Screen Integrity Tests at Wapatn Canal Fish Screening Facility, Spring $1987 \ldots . . . \ldots \ldots$.

B.32 Estimated Time to Capture $50 \%$ and $95 \%$ of Fall Chinook Salmon Fry Oncorhynchus tshawytscha Released in Screen Integrity Tests at Wapato Canal Fish Screening Facility.

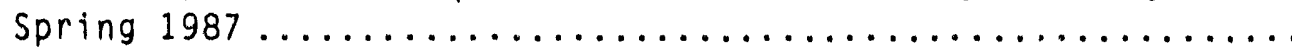

B.33 Percentage of Steelhead Oncorhynchus mykiss Smolts Descaled or Killed in Tests of the Inclined Plane at the Toppenish Creek Canal Fish Screening Facility. Spring 1988 
B.34 Percentage of Steelhead Oncorhynchus mykiss Smolts Descaled Lefore Being Used in Tests at the Toppenish Creek Canal Fish Screening Facility, Spring $1988 \ldots \ldots \ldots \ldots \ldots \ldots \ldots \ldots \ldots$

B.35 Descaling a.7d Mortality Data from Release and Capture Tests with Steelhead Oncorhynchus mykiss Smolts at the Toppenish Creek Fish Screening Facllity. Spring $1988 \ldots \ldots \ldots \ldots \ldots \ldots$

B.36 Estimated Time to Capture $50 \%$ of Steelhead Oncorhynchus mykiss Smoltis Released in Descaling Tests at Toppenish Creek Fish Screening Facility, Spring 1988

B.37 Estimated Time to Capture 50\% of Rainbow Trout Oncorhynchus mykiss Fry Released in Screen Integrity Tests at Toppenish Creek Fish Screening Facility. Spring $1988 \ldots \ldots \ldots \ldots \ldots \ldots \ldots$

B.38 Percentage of Steelhead Oncorhynchus mykiss Smolts Descaled in Pipe Tests at the Toppenish Creek Fish Screening Facility.

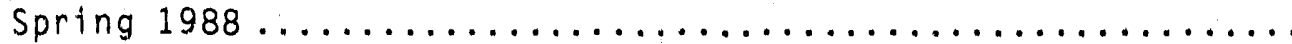

B.39 Capture Data for Rainbow Trout Oncorhynchus mykiss Fry Released During Screen Integrity Tests at the Toppentsh Creek Fish Screening Facility, Spring $1988 \ldots . . \ldots \ldots \ldots \ldots . . . .$.

B.40 Capture Efficiency of the Inclined Plane and Fyke Nets Used During Screen Integrity Tests at the Toppenish Creek Fish Screening Facility, spring $1988 \ldots \ldots \ldots \ldots \ldots \ldots \ldots \ldots \ldots \ldots$

B.41 Estimated Time to Capture $50 \%$ of Fall Chinook Salmon Oncorhynchus tshawytscha Fry Released in Screen Integrity Tests at the Wapato Fish Screening Facility, Spring 1988 .....

B.42 Capture Data for Fall Chinook Salmon Oncorhynchus tshawytscha Fry Released During Screen Integrity Tests at the Wapato Canal Fish Screening Facility, Spring $1988 \ldots \ldots \ldots \ldots \ldots \ldots \ldots$

B.43 Capture Efficiency of the Inclined Plane and Nets and Retention Efficiency for Fyke Nets Used During Screen Integrity Tests at the Wapato Canal Fish Screening

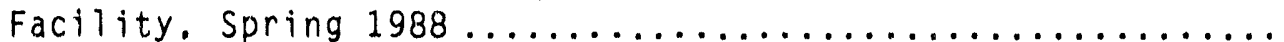

B.44 Capture Data from Fyke Nets Behind Selected Screens at the Wapato Canal Fish Screening Facility After the Release of Yakima Indian Nation Fall Chinook Salmon Oncorhynchus tshawytscha from Net Pens in the Wapato Screen Forebay. Spring 1988

B.45 Estimated Time to Capture $50 \%$ of Fall Chinook Oncorhynchus tshawytscha Fry Keleased in Screen Integrity Tests at the Sunnyside Fish Screening Facility. Spring 1988 
B.46 Capture Data for Fall Chinook Salmon Oncorhynchus tshawytscha Fry Released During Screen Integrity Tests at the Sunnyside Fish Screening Facility. Spring $1988 \ldots \ldots \ldots \ldots \ldots \ldots \ldots \ldots$ B.33

B.47 Capture Efficiency of the Inciined Plane and Fyke Nets Used During Screen Integrity Tests at the Sunnyside Canal Fish Screening Facility. Spring 1988

B.48 Capture Data From Fyke Nets Behind Selected Screens at the Sunnyside Canal Fish Screening Facility After the Release of Yakima Indian Nation Fall Chinook Salmon Oncorhynchus tshawytscha Fingerlings From the Wapato

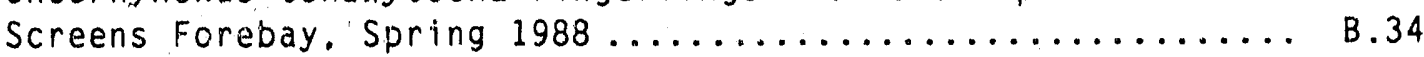




\section{INTRODUCTION}

The Yakima River Basin historically has supported significant salmon runs. During the late $1800 \mathrm{~s}$, between 500,000 and 600,000 adult salmon and steelhead Oncorhynchus spp. returned yearly to the Yakima River and its tributaries (Bureau of Reclamation 1984). Salmon runs included several races: spring, summer, and fall chinook salmon 0 . tshawytscha, coho salmon 0 . kisutch. sockeye salmon 0 . nerka, and steelhead 0 . mykiss. Some runs are now extinct or are nearing extinction. In the early 1980s, spawning escapement averaged about 2000 salmonids (Bureau of Reclamation 1984). Today, there is no sockeye run in the Yakima River Basin, and in 1983 only 37 coho salmon passed the Prosser Diversion Dam (Hollowed 1984). Recent improvements in efforts to manage and enhance salmonid runs in the Yakima River increased the total spawning escapement to 5 - to 10 -thousand adults in the late 1980s (Fastet al. 1986).

Reduced numbers of salmonids returning to the Yakilna River Basin reflect many factors. Spawnirg and rearing habitat is less because of reduced instream flow downstream from irrigation diversion dams. Ineffective fish passage facilities for adults and juveniles at diversion dams cause high mortality during migration. Additionally. many Yakima River fish are killed while passing hydroelectric dams on the mainstem Columbia River.

The Pacific Northwest Electric Power Planning and Conservation Act (Public Law 96-501) was passed to enable preparation and implementation of a regional Conservation and Electric Power Plan. The Northwest Power Planning Council. which administers the Plan, is charged with developing a program to protect and enhance fish and wildife populations and to mitigate adverse effects from development, operation, and management of hydroelectric facilities.

The Yakima River Basin was selected as one site for enhancing salmon and steelhead runs. Under the Plan, the Bonneville Power Administration (BPA) and the Bureau of Reclamation (BR) fund tl. a construction of fish passage and protection facilities at irrigation and hydroelectric diversions in the Yakima River Basin (Figure 1). BPA also provides funds to the Yakima Indian Nation to increase production of spring chinook salmon in the Yakima River Basin.

Construction of the Wapato. Sunnyside, and Toppenish Creek Canal Fish Screening Facilities (Wapato. Sunnyside, and Toppenish Creek Screens) was completed in 1985, 1987, and 1988 respectively. During 1985. BPA asked the Pacific Northwest Laboratory ( $P N L$ ) to evaluate the effectiveness of these diversion facilities in returning fish that had entered the canals to the river. The work plan for this study was designed to determine if diverted fish are safely and expeditiously returned to the river. Tests were 


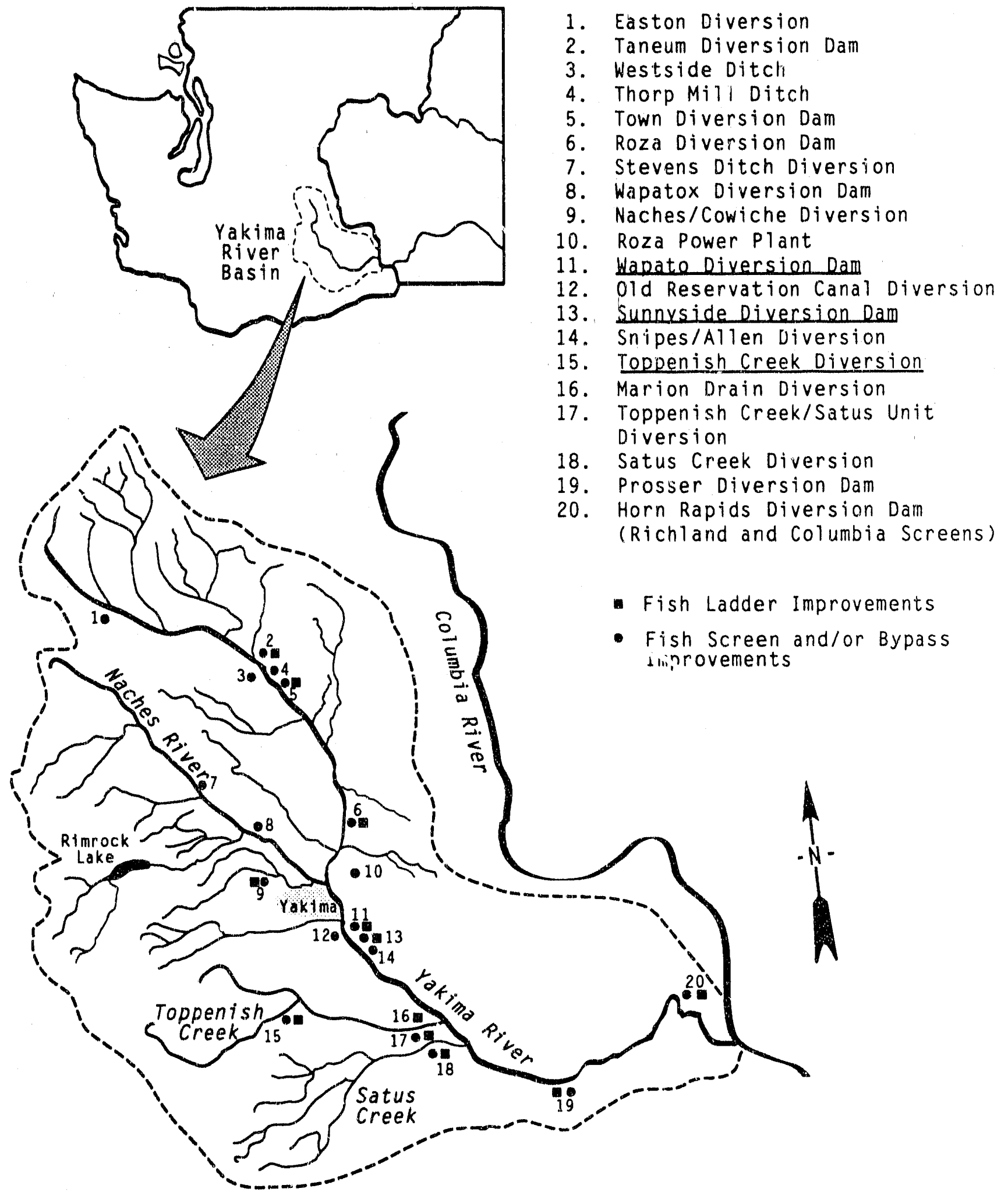

EIGURE 1. Yakima River Basin Showing Locations of the Toppenish Creek. Wapato, and Sunnyside Canal Fish Screening Facilities and Other Fish Proteciion and Passage Facilities 
conducted to 1) evaluate conditions or circumstances that affect fish survival as they pass through the screening facility: 2) determine if a screening facility provides conditions under which diverted fish may become more susceptible to predation: 3 ) evaluate whether fish are delayed at or upstream of the screening facilities: and 4 ) determine if fish pass through, around. or over rotary-drum screens and become trapped in the irrigation canal. Operating conditions at each facility vary, resulting in different conditions for bypassed or diverted fish. The work plan includes tests to determine the potential for adverse conditions resulting from changes in operating conditions.

This report covers work completed in 1988 by PNL fisheries staff at the Wapato. Sunnyside, and Toppenish Creek Screens. The report describes each screen facility, methods used to evaluate screen effectiveness, and test results. Our findings are discussed and compared with those from previous tests at the Sunnyside Screens (Neitzel et al. 1985), the Richland and Toppenish/Satus Screens (Neitzel et al. 1987), and the Richland and Wapato screens (Neitzel et a1. 1988). The report includes three appendices. Appendix $\therefore$ de.crives the work plan prepared to guide the evaluations and associate specific objectives with the methods used during the evaluations. Appendix $B$ includes data tables for the Sunnyside Screens in 1985. the Richland and Toppenish/Satus Screens in 1986, the Richland and Wapato Screens in 1987, and the Wapato. Sunnyside, and Toppenish Creek screens in 1988. Appendix $C$ describes the operating criteria used to set flows at the screening facilities. 


\section{STUDY AREAS}

During 1988, we conducted studies at Toppenish Creek, Wapato, and Sunnyside screening facilities. Toppenish creek study area included the canal from trash rack to fish bypass, the canal immediately behind the screens, and the fish return pipe. The Wapato and Sunnyside study areas included screen forebays, terminus of the fish bypass system, and the canal behind the screens. Our study area description includes the site operating conditions.

\section{IOPPENISH CREEK SCREENS}

Water is diverted from Toppenish Creek into the Toppenish Creek Canal about $8.3 \mathrm{~km}(5 \mathrm{mi})$ south of White Swan. Washington (Figure 2). Carrying capacity of the Toppenish Creek Canal is about $1.7 \mathrm{~m}^{3} / \mathrm{s}$ [60 cubic feet per second (cfs)]. Canal flow varies from 0.3 to $1.7 \mathrm{~m}^{3} / \mathrm{s}$ ( 10 to $60 \mathrm{cfs}$ ) seasonally and is regulated at the canal head gates about $i 5 \mathrm{~m}(246 \mathrm{ft})$. upstream of the Toppenish Screens. The screening facility (Figure 3 ) diverts fish that enter the canal and directs them back to Toppenish Creek. Trash racks placed in the canal about $10 \mathrm{~m}(33 \mathrm{ft})$ upstream of the screening facility "filter" out large debris that could damage the screens or interfere with flow control through the screen facility.

The screening facility houses three rotary-drum screens with axes parallel to the length of the structure (Figure 3 ). Each screen is about $4 \mathrm{~m}$ $(12 \mathrm{ft})$ wide and $1.8 \mathrm{~m}(6 \mathrm{ft})$ in diameter. Screen mesh openings are $3.18 \mathrm{~mm}$ ( $1 / 8 \mathrm{in.})$. Water depth at the screens varies with canal flow. The average water depth across the face of the screens is about $1 \mathrm{~m}(3 \mathrm{ft})$.

The rotary screens are installed at an angle of $26^{\circ}$ to canal flow. This orientation provides a ratio of sweeping velocity to approach velocity equal to or exceeding 2:1 (Easterbrooks 1984). Maximum-allowable approach velocity is $0.15 \mathrm{~m} / \mathrm{s}(0.5 \mathrm{f} / \mathrm{s})$. Screen orientation and $\mathrm{flow}$-velocity differential help direct fish to the fish return pipe and back to the creek.

\section{WAPATQ CANAL}

The Wapato Diversion (Figure 2) is located at river kilometer ( $\mathrm{km}$ ) 172 [river mile (RM) 106.7] on the Yakima River. The diversion directs water from the Yakima River into the Wapato Canal. Canal operation begins in early March and continues through the irrigation season usuall" until midoctober. Canal capacity is about $57 \mathrm{~m}^{3} / \mathrm{s}$ (2000 cfs). 


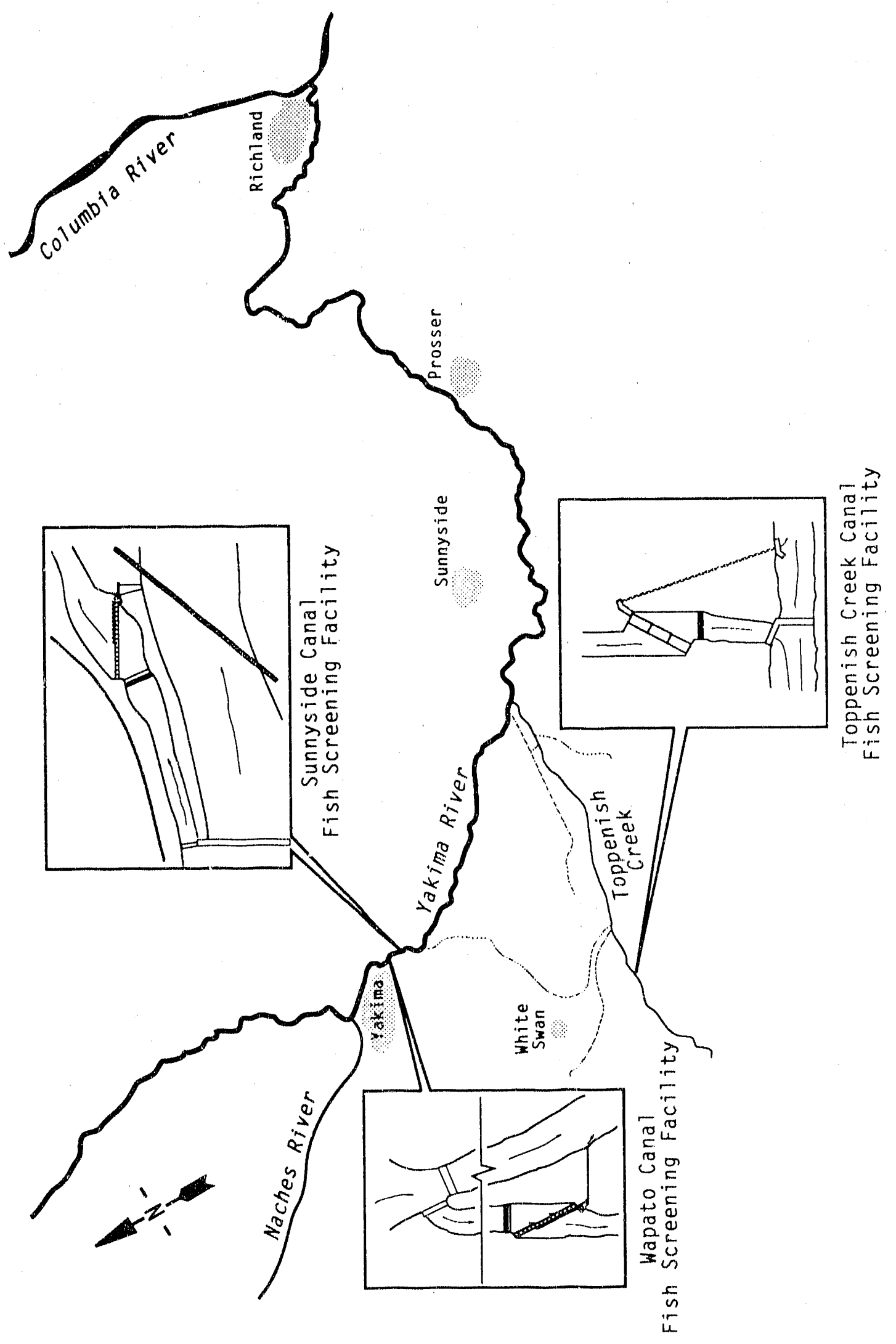

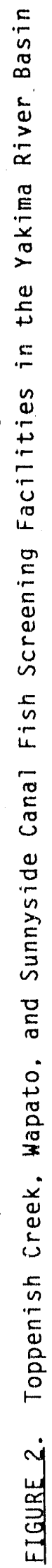




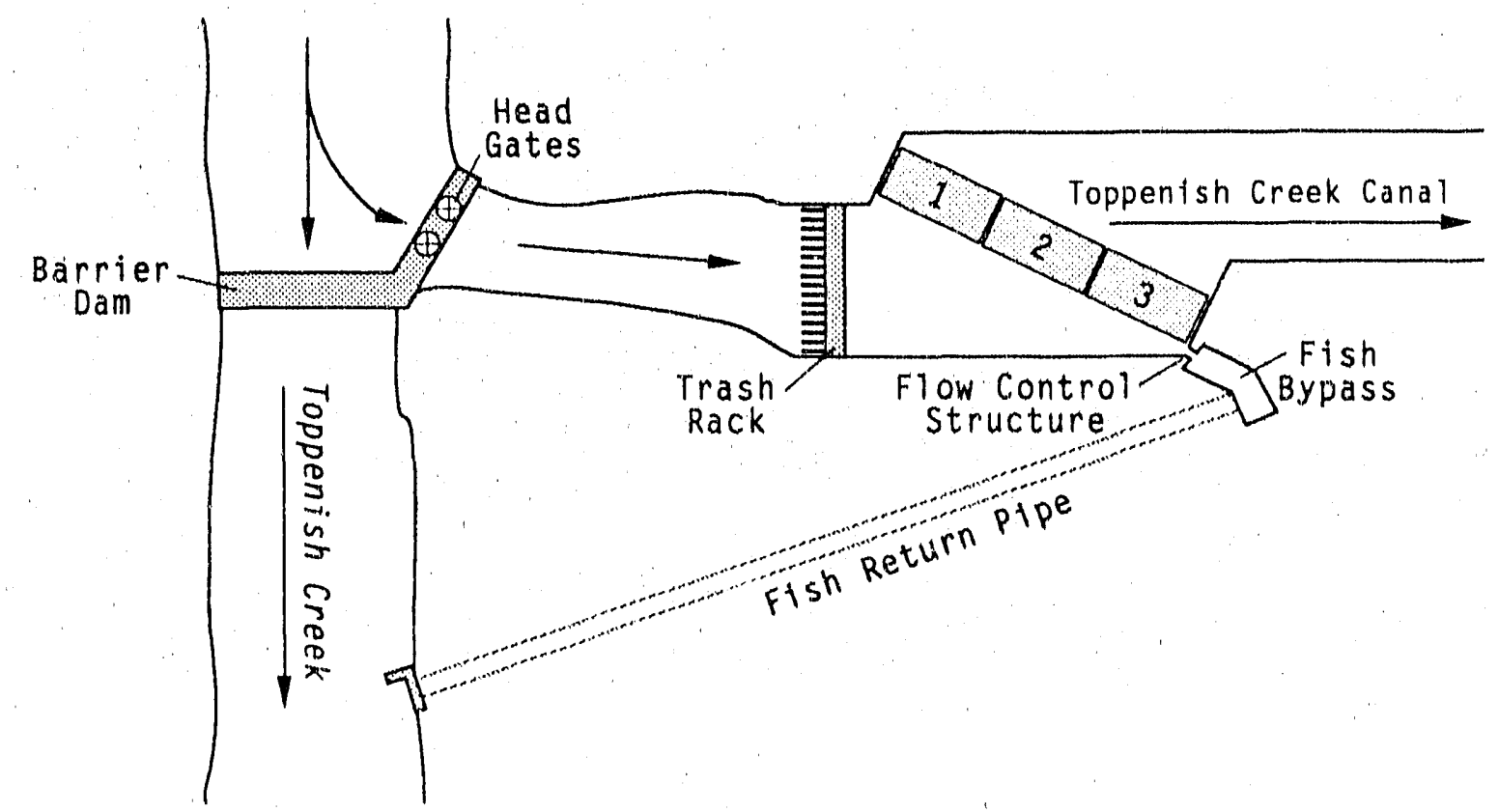

EIGURE 3. Flow Control Structure and Fish Bypass System in the Toppenish Creek Canal Fish Screening Facility

The Wapato Screens are located about $1 \mathrm{~km}(0.6 \mathrm{mi})$ downstream of the liead gates for the Wapato Canal. The screening facility (Figure 4 ) diverts fish entering the canal and directs them back to the Yakima River.

Trash racks from the old screening facility are immediately upstream of the new Wapato Screens. The racks "filter" out debris entering the canal. The screening facility houses 15 rotary drum screens with axes parallel to the length of the structure (Figure 4 ). Each screen is about $7.3 \mathrm{~m}$ ( $24 \mathrm{ft}$ ) wide and $4.6 \mathrm{~m}(15 \mathrm{ft})$ in diameter. Water depth at the screens varies with canal flow; depth across the face of the screens at full canal level is normally about $3.7 \mathrm{~m}(12 \mathrm{ft})$.

The flow control structure and separation chamber are located at the downstream end of the screen facility (Figure 4). Two fish bypass pipes and the terminal bypass, each with a flow of about $1.4 \mathrm{~m} 3 / \mathrm{s}$ ( $50 \mathrm{cfs}$ ). feed into the separation chamber. During normal operation, about $4.2 \mathrm{~m} 3 / \mathrm{s}$ ( $150 \mathrm{cfs}$ ) of water enter the separation chamber. About $0.9 \mathrm{~m} 3 / \mathrm{s}$ ( $30 \mathrm{cfs}$ ) of water and all fish in front of the rotating screens, pass through the flow control structure and out the fish return pipe. Two bypass-water return pumps, each with a pumping capacity of $1.4 \mathrm{~m}^{3} / \mathrm{s}$ ( $50 \mathrm{cfs}$ ), are located behind traveling screens near the terminus of the separation chamber. The traveling screens are equipped with screen washers to prevent fish and debris from being entrained in the pump-back system. 


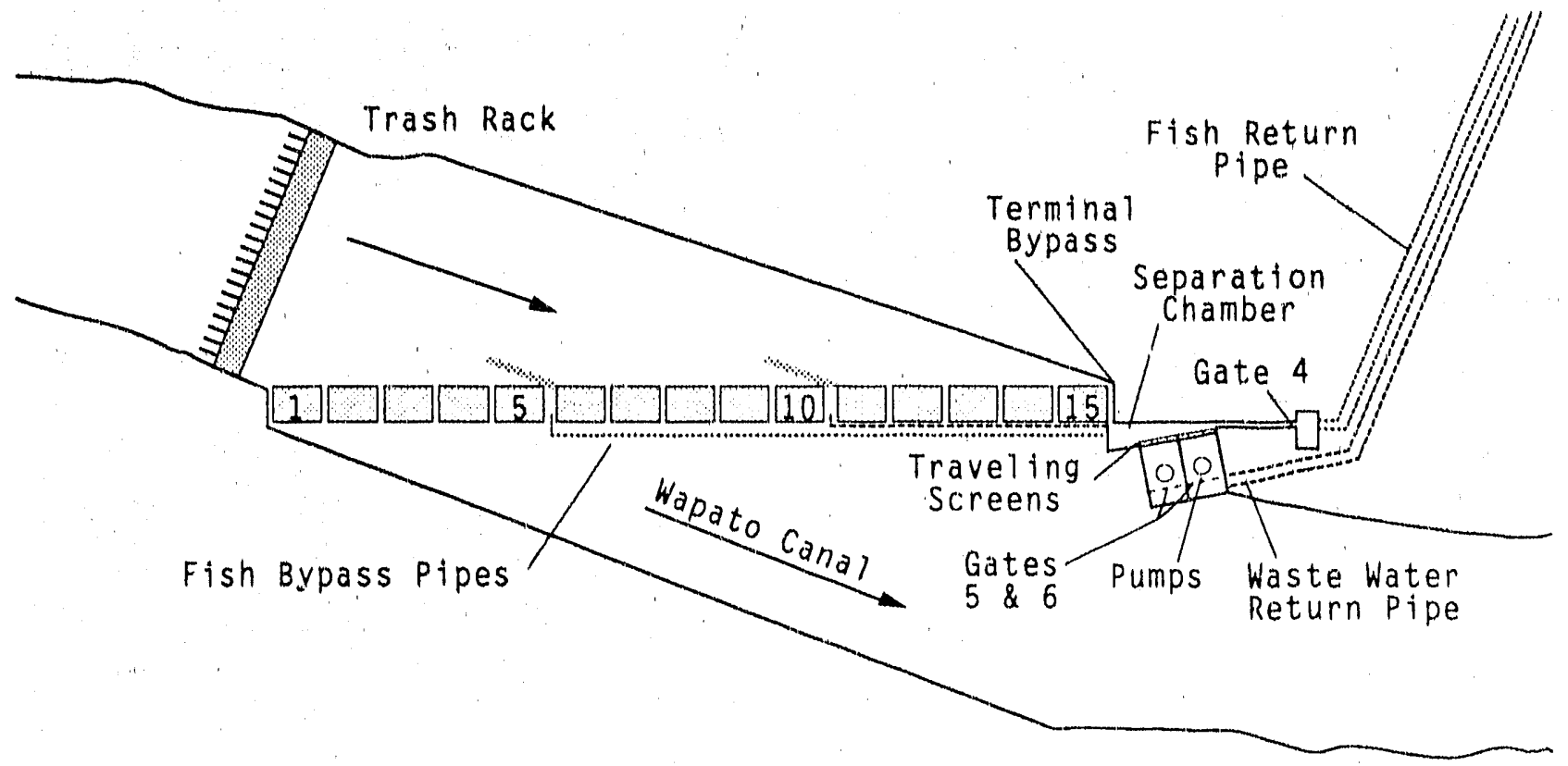

EIGURE 4. Flow Control structure and Fish Bypass system in the wapato Canal Fish Screening Facility

The pump-back system is not used during normal operation. Adequate flows are maintained in the fish bypass by discharging $3.4 \mathrm{~m} 3 / \mathrm{suc}$ ( $120 \mathrm{cfs}$ ) of water back to the Yakima River over adjustable weirs in the pump basin. Flow over the weirs is reduced when the pumps are operating. Thus, bypass flows die achleved by adjusting weirs in each fish bypass (Gates 1.2. and 3 ), the fish return (Gate 4 ), and the two weirs behind the pump intakes (Gates 5 and 6 ).

\section{SUNNYSIDE CANAL}

The Sunnyside Diversion (Figure 2) is located at river km 167 (RM 103.8) on the Yakima Piver. The diversion directs water from the Yakima River into the Sunnyside Canal. Canal operation begins in early March and continues through the irrigation season usually until mid-October. Canal capacity is about $37 \mathrm{~m}^{3} / \mathrm{s}(1300 \mathrm{cfs})$.

The Sunnyside Screens are located about $0.4 \mathrm{~km}(0.25 \mathrm{mi})$ downstream of the head gates of the sunnyside Canal. The screening facility (Figure 5) diverts fish entering the canal and directs them back to the Yakima River. The trash rack immediately upstream of the sunnyside scrcens "filters" out debris entering the canal. The screening facility houses 17 rotary-drum 


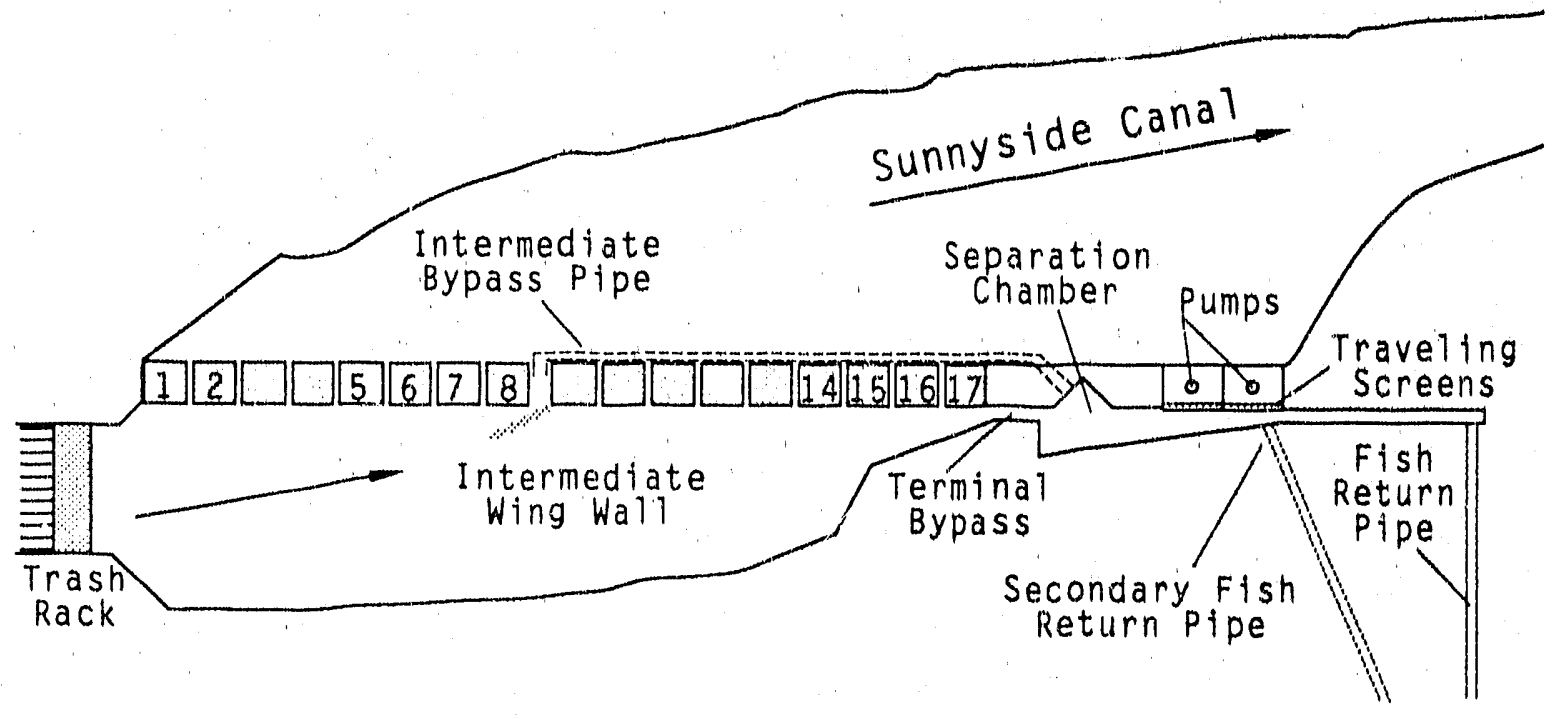

EIGURE 5. Flow Control Structure and Fish Bypass system in the sunnyside Canal Fish Screening Facility

screens (Figure 5) with axes parallel to the length of the structure. Each screen is about $3.7 \mathrm{~m}(12 \mathrm{ft}$ ) wide and $4.6 \mathrm{~m}(15 \mathrm{ft})$ in diameter. Water depth at the screens varies with canal flow. Water depth across the face of the screens at full canal level is normally about $4.3 \mathrm{~m}$ (14 ft).

The flow control structure and separation chamber (Figure 5) are located at the downstream end of the screen facility. An intermediate bypass pipe and the terminal bypass, each with a flow of about $1.4 \mathrm{~m}^{3} / \mathrm{s}$ ( $50 \mathrm{cfs}$ ), feed into the separation chamber. During normal operation, about $2.8 \mathrm{~m}^{3} / \mathrm{s}$ ( $100 \mathrm{cfs}$ ) of water enter the separation chamber. About $0.6 \mathrm{~m}^{3} / \mathrm{s}$ ( $20 \mathrm{cfs}$ ) of water. and all fish in front of the screens. pass through the flow control struc. ture and out the primary fish return pipe. Two bypass water return pumps, each with a pumping capacity of $1.1 \mathrm{~m}^{3} / \mathrm{s}$ ( $40 \mathrm{cfs}$ ), are located behind vertical traveling screens near the terminus of the separation chamber. Traveling screens are equipped with screen washers to prevent fish and debris from being entrained in the pumpback system. During periods when one or no pumps are operating, water is discharged through a secondary fish-return pipe. 


\section{METHODS}

Two types of studies were conducted in 1988: descaling tests at Toppenish Creek, and screen integrity tests, at Toppenish Creek. Wapato, and Sunnyside. In descaling tests, fish were released upstream of the screen facility and captured at the terminus of the fish bypass slot or released at the head of the fish return pipe and captured at the terminus of the pipe. Some fish were held for post-test observation. Native salmonids entering the diversion canal were also monitored during release/capture tests. In screen integrity tests. fish were released both in front of and behind the screens. Fish were recaptured as they appeared in the fish return or in fyke nets mounted behind the drum screens.

\section{IESI FISH}

The species selected for testing were recommended by fisheries biologists from the Washington State Department of Fisheries (WDF), the U.S. Fish and Wildlife Service (USFWS), and the Yakima Indian Nation. Species selection was based on the potential for a specific salmonid population encountering a screening factitity during their rearing and outmigration. Selection was dependent on the species, race, and size of salmonids occurring in the Yakima River drainage upstream of each diversion.

Steelhead and resident rainbow trout use the Yakima River and its tributaries, including Toppenish Creek. Spring chinook salmon use the Yakima River and some of the tributaries above the Wapato and Sunnyside diversions. Fall chinook salmon. which now spawn only downstream of the Wapato Diversion. may use upriver areas as the population builds. Additionally. fall chinook salmon are currently reared in net pens in the wapato Screen forebay. These fish are released as fingerlings in front of the screens.

Steelhead smolts were selected to evaluate descaling and rainbow trout fry ( $<50 \mathrm{~mm}$ ) were chosen to evaluate screen integrity at the Toppenish creek screens. Fall chinook salmon fry $(<60 \mathrm{~mm})$ were selected for screen integrity tests at the Wapato and Sunnyside Screens.

\section{Steelhead}

Yearling steelhead were obtained from the Washington Department of Wildi ife Lyon's Ferry Hatchery. Wells-strain steelhead were hatched, reared, and adipose fin-clipped at the hatchery prior to acquisition. Fish weighing about $15 \mathrm{fish} / \mathrm{kg}$ ( 6 to $8 \mathrm{fish} / 1 \mathrm{~b}$ ) were transferred to PNL on March 8. 1988. The fish were acclimated outdoors in fiberglass circular tanks supplied with a mixture of Columbia River and well water at $10^{\circ} \mathrm{C}$. Fish were coldbranded using stainless steel rods cooled by liquid nitrogen. Fish were acclimated to temperatures expected at Toppenish Creek at least 1 week before release. 


\section{Bainbow Irout}

Rainbow trout fry used in the Toppenish Creek integrity tests were obtatred from PNL-brood stock spawned in November 1987. Eggs were hatched in vertical-flow incubators supplied with $10^{\circ} \mathrm{C}$ well water. Fry were transferred to troughs and reared at $10^{\circ} \mathrm{C}$ until testing. Ralnbow trout fry averaged 47.3 $\mathrm{mm}(2 \mathrm{in}$.$) fork length ( \mathrm{Fl}$ ) and weighed $1.3 \mathrm{~g}(350 \mathrm{flsh} / \mathrm{lb})$ when tested.

\section{Fall chinook salmon}

Fall chinook salmon eyed eggs were obtained from the Bonneville Hatchery, operated by the Oregon Department of Fish and Wildlife. Eggs were spawned at the WDF's Priest Rapids Hatchery near Mattawa. Washington. reared to the eyed stage at the Willamette Hatchery, and transferred as eyed eggs to the Bonneville Hatchery. Eggs were transferred to PNL on January 22. 1988. The eggs were hatched in vertical-flow incubators supplied with $10^{\circ} \mathrm{C}$ well water. Fry were transferred to troughs and reared at $10^{\circ} \mathrm{C}$ unt 11 used for screen integrity tests at Wapato and Sunnyside. Fry weighed $830 \mathrm{fish} / \mathrm{kg}$ $(375 \mathrm{fish} / 1 \mathrm{~b})$ and measured $49 \mathrm{~mm}$ ( $2 \mathrm{in.}$ ) Fl at testing.

\section{SAMPLING EQUIPMENT}

Fish were captured efther within the screening facllity, at the terminus of the primary fish-return pipe, or in the canal behind the screens, based on the test objective. Inclined planes were custom-butit to fit the fish bypass structures at each site. A selne, dip nets, and an electroshocker were used to collect fish at the terminus of the Toppenish Creek fish return pipe. Fyke nets mounted in stoplog slots behind the rotary-drum screens were used to collect fish behind the screens. Temporary fish holding factlities were installed at each test site to acclimate test fish.

\section{Inclined Plane}

Fish were captured with an inclined plane in the fish return between the last rotary-drum screen and the head of the fish return pipe. The inclined plane at the Toppenish Creek Screens (Figure 6) was $1.9 \mathrm{~m}(6.3 \mathrm{ft}$ ) 1 ong and $0.9 \mathrm{~m}(3.0 \mathrm{ft})$ wide. The front face of the plane was hinged so that the slope of the plane could be changed to adjust the flow of water reaching the fish live box. Solid walls, tapering from $0.9 \mathrm{~m}(3 \mathrm{ft})$ at the entrance to $0.3 \mathrm{~m}(1.0 \mathrm{ft})$ at the live box. acted as splash guards to reduce fish loss from the plane. The live box $[0.36 \mathrm{~m}(1.2 \mathrm{ft})$ long by $0.9 \mathrm{~m}(2.5 \mathrm{ft})$ wide. 1001 (26 gal) volume] was fastened at the end of the inclined plane. The inclined plane had an aluminum frame covered with a perforated aluminum sheet $[0.32-\mathrm{cm}-(1 / 8-i n .-)$ diameter holes, staggered centers, $40 \%$ open]. 


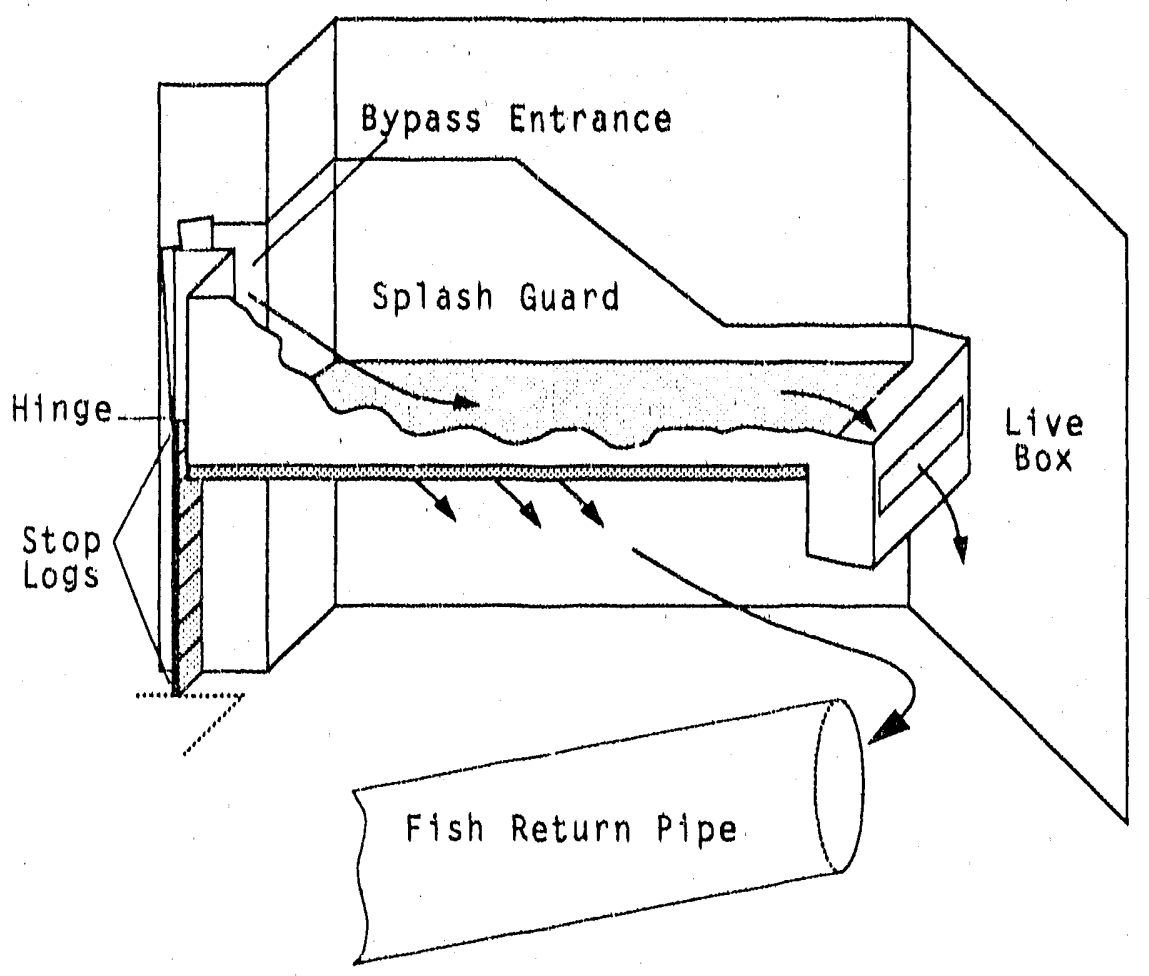

EIGURE 6. Inclined Plane Used at the Toppenish Creek Canal Fish Screening Facility, Spring 1988

Flow was directed over the plane by inserting dam boards in the upstream stoplog slot in the fish bypass slot. The height of the dam boards relative to the water depth determined the water volume through the fish bypass.

The inclined plane used at Wapato captured fish in the primary fish return downstream of Gate 4 at the terminus of the fish return slot (Neitzel et $\left.\mathrm{a}^{\prime}, 1987\right)$. The plane was $1.5 \mathrm{~m}(5 \mathrm{ft})$ wide and $2.13 \mathrm{~m}(7 \mathrm{ft})$ 1ong. The surface of the plane was covered with a perforated aluminum sheet $[0.32-\mathrm{cm}$ $(1 / 8$-in.) holes, $40 \%$ open $]$. A live box $[0.3 \mathrm{~m}(1 \mathrm{ft})$ long by $0.61 \mathrm{~m}$ ( $2 \mathrm{ft}$ ) wide and $0.46 \mathrm{~m}(1.5 \mathrm{ft})$ deep] with a volume of 85.1 (22 gal) was attached to the end of the plane. Aluminum walls $[0.6 \mathrm{~m}(2 \mathrm{ft})$ high] were welded to the edges of the plane, and the corners of the plane surface were elevated $0.3 \mathrm{~m}(1 \mathrm{ft})$ to help guide the $\mathrm{ftsh}$ toward the live box. The valume of water enteriny the plane was controlled by stop-logging at Gate 4 . Bureau of Reclamation personnel set Gate 4 to the specifications outlined in the oferating criteria (Appendix $C$ ) before each test.

The inclined plane used at Sunnyside was similar to that used at Toppenish creek, having a hinged front face and solid-metal splash guards. The plane was built to fit in the primary fish-return slot and was $0.56 \mathrm{~m}(1.8 \mathrm{ft})$ wide. $3.0 \mathrm{~m}(9.8 \mathrm{ft})$ long. A live box $(0.3 \mathrm{~m}$ long. $0.56 \mathrm{~m} \mathrm{wide}$, and $0.3 \mathrm{~m}$ deep with a volume of 501 ) was attached to the end of the plane. The plane had an aluminum frame covered with a perforated aluminum sheet 
[0.32 cm- (1/8-in.-) diameter holes, staggered centers, $40 \%$ open]. Flow was directed over the plane by inserting dam boards in the upstream stoplog slot in the fish bypass slot.

Inclined planes were lowered into position with hand hoists. The perforated plates were brushed periodically to prevent clogging by vegetation and debris because clogging restricted the plane's abtlity tio filter water and separate fish from the bypass water.

\section{Eyke Nets}

Fyke nets were used to capture fish in integrity tests at all sites. At Toppenish creek. One net was placed behind each drum screen. The nets were $3.8 \mathrm{~m}(12.5 \mathrm{ft})$ wide and $1.2 \mathrm{~m}(4 \mathrm{ft})$ deep. Tops of the nets were above the waterline, and bottoms of the nets settled into the mud on the canal floor. The net tapered over a length of $2.4 \mathrm{~m}(\mathrm{~s} \mathrm{ft})$ from a 12.5 by $4 \mathrm{ft}$ mouth down to a $0.6 \mathrm{~m}-(2 \mathrm{ft}-)$ square cod-end net. The cod-end net was $1.8 \mathrm{~m}$ ( $6 \mathrm{ft}$ ) long, resulting in an overall length of $4.3 \mathrm{~m}$ ( $14 \mathrm{ft}$ ). The cod-end net was tied shut with a rope. Fish and trash were removed from the cod-end of the nels without lifting the net mouths from the water.

Six fyke nets were used in the Wapato Canal screen integrity tests. Because of the screen width at Wapato. two nets were required behind one screen. The nets were fished immediately downstream of three selected screens during a test. The nets were $3.65 \mathrm{~m}(12 \mathrm{ft})$ square. Tops of the nets were above the waterline, and net bottoms settled into the mud on the canal floor. Nets tapered from a $3.65-\mathrm{m}-(12-\mathrm{ft}-)$ square mouth to a $1.22-\mathrm{m}$ $(4-\mathrm{ft})$ square over a distance of $6.1 \mathrm{~m}(20 \mathrm{ft})$. The $1.22-\mathrm{m}-(4-\mathrm{ft}-)$ square sock extended back another $6.1 \mathrm{~m}(20 \mathrm{ft})$ to make the total length of the net $12.2 \mathrm{~m}(40 \mathrm{ft})$. A zipper was installed near the end of the sock to facilitate fish removal. Net frames were raised from the water to recover fish in the nets.

Eight fyke nets were used at Sunnyside. Nets were fished immediately downstream of four selected screens during testing. Two nets, one fishing the upper one-third and one fishing the lower two-thirds of the water column, were used behind each of the four screens (Figure 7). Two nets per screen were used because of the location of the intermediate fish bypass pipe behind the screens. The mouth of the top net was $3.7 \mathrm{~m}(12.2 \mathrm{ft})$ wide and $1.5 \mathrm{~m}(5 \mathrm{ft})$ deep, and the mouth of the bottom net was $3.7 \mathrm{~m}(12.2 \mathrm{ft})$ wide and $2.8 \mathrm{~m}(9.0 \mathrm{ft})$ deep. Both nets were $9.1 \mathrm{~m}(30 \mathrm{ft})$ long. The nets tapered from the mouth dimensions to a $0.6 \mathrm{~m}$ - (2 ft-) square cod-end net over a length of $6.1 \mathrm{~m}(20 \mathrm{ft})$. The cod-end nets were $3.0 \mathrm{~m}(10 \mathrm{ft})$ long and were tied shut. Each pair of net frames were bolted together to prevent fish from passing between the nets. Net frames were raised from the water to recover fish in the nets. 


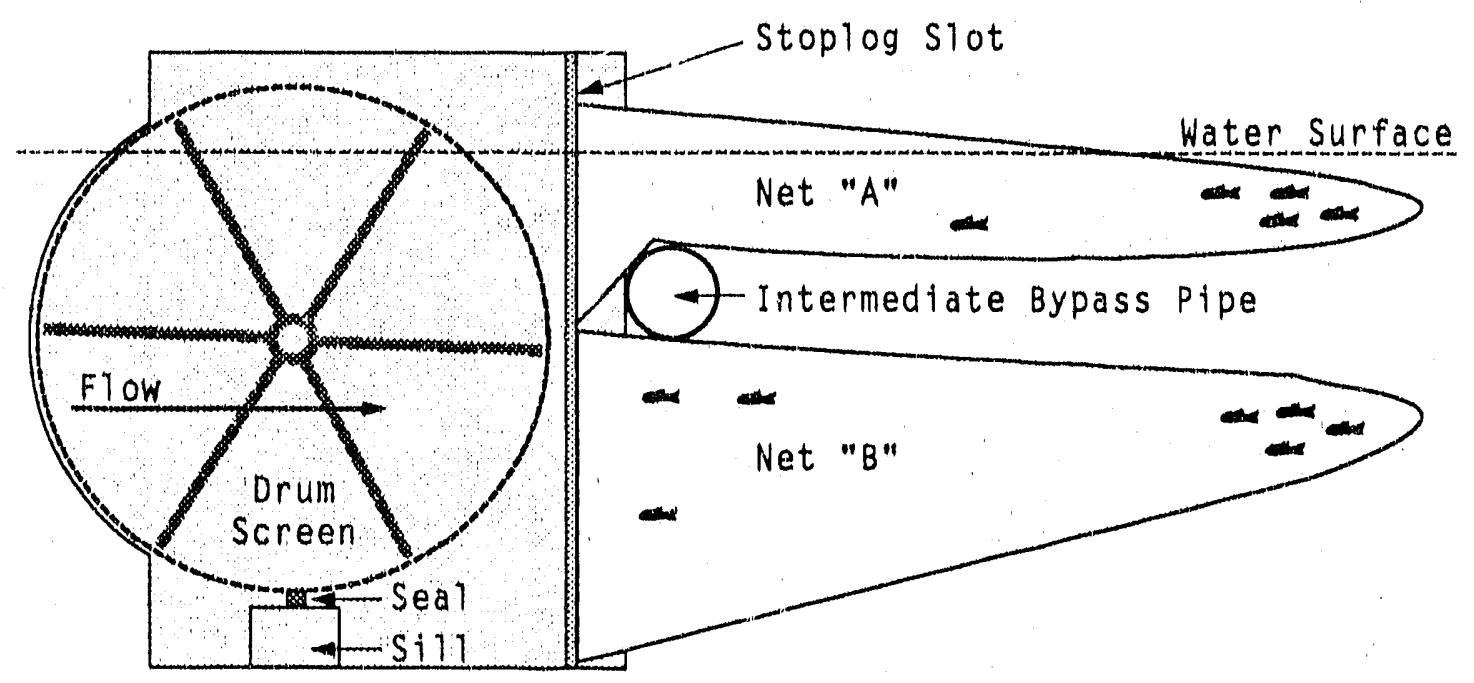

EIGURE 7. Fyke Nets Used in Integrity Tests at the Sunnyside Screens, Spring 1988

\section{Electrofishing}

At the Toppenish Crepk Screens, an alternator and gas-powered generator were used to electrically stun fish. Stunned fish were collected with a beach seine at the terminus of the fish return pipe. The shocker probes were placed near the end of the pipe, and the seine was used to confine stunned fish until they could be captured by dip net.

\section{HOLDING FACILITIES}

Temporary facilities were installed to hold fish during descaling evaluation and to retain some fish for $96 \mathrm{~h}$ after capture. A mobile laboratory containing three fiberglass troughs $[3 \mathrm{~m}(10 \mathrm{ft})$ long by $0.56 \mathrm{~m}$ $(1.8 \mathrm{ft})$ wide, $0.25 \mathrm{~m}(0.8 \mathrm{ft})$ deep, and 5401 (140 gal) in volume], and two fiberglass circular tanks $[1.22 \mathrm{~m}(4 \mathrm{ft}$ ) in diameter by $0.6 \mathrm{~m}$ (2 ft) deepl were installed at each site. All tanks were supplied with canal water pumped from behind the screens. The mobile lab was equipped with fluorescent lighting to evaluate fish captured cluring both the day and night for descaling under similar light conditions.

\section{DESCALING EVALUATION}

The evaluation system developed by the U.S. Army Corps of Engineers (Basham et al. 1982) was used to monitor the condition of fish. Evaluation criteria included modifications established in 1985 (Neitzel et al. 1985). Baseline descaling condition was determined by randomly sampling groups of test fish before release. Descaling was evaluated in each of 10 areas. 
5 on tach side of the fish. When $40 \%$ or more scale loss was observed in any 2 areas on one side of a fish, the fish was classified as descaled.

\section{IEST PROCEDURE}

Descaling evaluations at the Toppenish Creek Screens involved introducing branded steelhead at the trash rack and capturing the fish when they appeared on the inclined plane in the primary fish return (Phase IIa, Appendix A). Tests were conducted in late March. Tests were initiated under low canal flow conditions. Flows were increased to maximum flows during the tests (Phase III. Appendix A). Fish were also released at the head of the fish return pipe and captured at the end in tests to evaluate effects of passage through the pipe (Phase IIb. Appendix A). Native salmonids were monitored during tests at the Toppenish Creek Screens (Phase IVa, Appendix A).

Screen integrity was evaluated at the Toppenish Creek. Wapato, and Sunnyside Screeris by releasing branded rainbow trout or fall chinook salmon in front of and behind the rotary screens (Phase IVD. Appendix A). Fish were collected as they appeared either on the iriclined plane in the fish return or in fyke nets placed in the canal behind the screens.

\section{Iest Stock identification}

Steelhead, rainbow trout, and fall chinook salmon were cold branded to identify specific test groups. Fish were marked in one of three locations: right anterior. left anterior. or right dorsal. Brands were applied at least 1 week before release. Brands were approved by the National Marine Fisheries Service (NMFS) and were distinguishable from all other brands used in the Columbia River Basin.

\section{Fish Iranspert and Release}

Test fish were transported at acclimation temperature in an insulated tank [400? (125 gal) in volume] supplied with oxygen. Transit times from PNL to the Toppenish Creek and Wapato or Sunnyside Screens were $2.0 \mathrm{~h}$ and $1.3 \mathrm{~h}$. respectively. Loading densities did not exceed $120 \mathrm{~g}$ of fish/l (1 1b/gal). Water temperature in the transporter changed less than $1^{\circ} \mathrm{C}$ during transit. Test fish were retted from the transporter and placed in holding tanks at the facility for acclimation before release. There were no losses attributabie to trarisporting stress.

\section{Eish Pelease Losations}

For descaling evaluation, test fish were released uniformly across the canal downstream of the trash rack at the Toppenish Creek. To evaluate the fish return pipe at Toppenish Creek, fish were released into the head-end 
of the pipe. Fish used in screen integrity tests were released in two locations. At Toppenish Creek, fish were released just upstream of the first rotary screen near the structure wall and uniformly across the mouth of the fyke nets positioned on the downstream side of the rotary screens. At Wapato and Sunnyside. fish were released in three locations: next to the concrete piers just upstream of the screens, in the fish bypass below each set of screens, and in fyke nets behind the screens.

\section{Release Controls}

Baseline condition of test fish was estimated by sampling each group before release at the Toppenish Creek Screens. Baseline-condition evaluations were conducted inside the mobile laboratory under artificial light. For Phase IIa tests. 210 fish were sampled for baseline condition and 755 fish were released into the Toppenish Creek Canal.

\section{Eish Capture and Evaluation}

Fish captured during Phase Ila tests were dip-netted from the live box of the inclined plane and placed in a holding tank before evaluation. Evaluations were made at half-hour intervals. Fish were anesthetized in MS-222, examined to determine the extent of scale loss, and returned to a holding tank. About 150 of the test fish were held $96 \mathrm{~h}$ to monitor delayed mortality. After fish recovered from the anesthetic, they were released to the creek or river via the fish return pipe.

Fish were captured by electroshocker and beach seine in phase IIb tests at the Toppenish Creek Screens. Fish were dipnetted from the seine quickly to reduce damage caused by turbulence in Toppenish Creek. Fish were anesthetized with MS-222, examined, held in a bucket until they had recovered from the anesthetic, and then were released into the creek.

Fish captured in Phase IVb tests were not evaluated for descaling. The purpose of Phase IVb tests was to determine the effectiveness of screening facilities in preventing fish from entering the canal behind the screens and to monitor the rate at which fish moved through the fish bypass. Fish were identified by brand group and enumerated as they appeared on the inclined plane in the fish return. The brands identified when and where fish were released within the screening facility.

In tests at Toppenish Creek. the inclined plane was fished up to $41 \mathrm{~h}$ after fish were released. Groups of fish were released both in front of and behind the screens at three different times: early afternoon. late after. noon, and evening. The fyke nets were left in place throughout the phase IVb tests. Nets were cleaned and the fish were retrieved from the cod-end of the nets several times each day. 


\section{SIATISIICAL ANALYSIS}

The amount of time for test fish to move from their release point to the inclined plane is estimated by the hours required to capture $50 \%$ of a test group. Capture efficiency of the inclined plane and the fyke nets used for screen integrity tests are estimated from the number of fish captured during a test. These data are used to estimate the efficiency of the screen in preventing fish from passing from the screen forebay to the canal downstream of the screens.

\section{Descaling and Mortality Estimates}

Estimates of the percent of fish descaled or killed were based on the number of test fish caught. Descaled fish were considered dead in evaluating results. The lower and upper confidence intervals. LCI and UCI, respectively, are estimated by

$$
L C I-\frac{B}{B+(n-B+1) F}
$$

and

$$
U C I-1-\frac{n-B}{n-B[n-(n-B)+1] F}
$$

where $B$ equals the number of dead or descaled fish, $n$ equals the number of fish caught, and $F$ equals a ratio of the estimates for the mean and individual sample variances. The estimates were calculated from Mainland's Tables (Mainland et al. 1956)

Data for replicate tests were combined to obtain a mean estimate. The estimate assumes each fish behaved independently (i.e.. fish within a test did not behave more similarly than did fish between tests and there were no interactions among fish within a test). Although some interaction among fish is expected. it is an assumption necessary for the analytical methods used. All tests were conducted in the same manner to reduce nonindependent behavior.

\section{Screen Efficiency Estimates}

The number of screens and bypass svstems are different at the three facilities tested. Therefore, the number of nets and the computation of screen efficiency varied. For Toppenish creek. Which has three screens, screen efficiencies were computed for each screen and for the entire facility. The 15 rotary-drum screens at the Wapato Screens are divided into three sections of five screens each separated by intermediate wing walls and bypass pipes. Screen efficiency estimates were computed for each of the screen sections in addition to an overall estimate. The 17 rotary-drum screens at Sunnyside are divided into 2 sections of eight and nine screens. separated by an intermediate wing wall. 
At Toppenish Creek, three tests with three groups of fish were conducted. Fyke nets were placed behind each screen for each test. Four screen efficiency tests were performed at Wapato. The first involved a 11 three screen sections, specifically screens 5, 10, and 15; the second. Section 3. screens 13, 14, and 15; the third test. Section 1, screens 3, 4, and 5; and the fourth. Section 3. screen 15. Although the method for estimating each section and the system is the same, input data are different in each case.

Three quantities must be computed to estimate screen efficiency. These are inclined plane efficiency (EFFip), net capture efficiency (EFFnc), and net retention efficiency $\left(E F F_{n}\right)$. Net retention is assumed to equal net efficiency at some sites, in which case net retention equals 1 . Given these quantities, the formula for computating screen efficiency (EFFSC) is

$$
E F F_{S C}=1-\frac{x_{n e t}}{E F F_{n C} E F F_{n r N}}
$$

where $X_{\text {net }}$ equals the number of fish released upstream of the screens and caught in the nets and $N$ is defined as follows:

$$
N=\frac{x_{n e t}}{E F F_{n c} E F F_{n r}}+\frac{x_{i p}}{E F F_{i p}}
$$

where $x_{i p}$ equals the number of fish released upstream of the screens and caught in the inclined plane. N represents the total number of fish released into the section being estimated. For some estimates and the overall estimate, after the efficiencies (EFFip. EFFnc, and EFFnr) have been considered. some fish are still not accounted for. To avoid making assumptions about what might have happened to these, an effective $N$ has been computed that is smaller than the actual number released. Thus, $N$ is not an actual accounting of all fish caught in different locations (inclined plane, fyke nets, bypass) but an estimate based on the actual numbers, adjusted by efficiencies for net losses and human error.

Efficiencies per set must also be defined. Input data for each section are as explained, combining across relevant tests. The general forms are

$$
E F F_{i p}=\frac{n_{i p}}{N_{i p}} \quad E F F_{n c}-\frac{n_{n c}}{N_{n c}} \quad E F F_{n r}-\frac{n_{n r}}{N_{n r}}
$$

where nip is the number of fish released in the bypass and caught in the inclined plane for the section estimated. Nip is the number released in the bypass. $n_{n c}$ is the number released in the net mouth and caught in the net. $N_{n c}$ is the number released in the net mouth. $n_{n r}$ is the number that remaining in the cod-end, and $\mathrm{N}_{n}$ is the number originally placed in the net cod end.

For overall efficiencies, individual section efficiencies cannot be simply averaged: rather, the efficiency is computed by combining all data. 
Averaging the separate sections would assume equal numbers were released in each test and weight them as such. By computing the overall estimates from all data lumped as one test, the varying $N$ values are incorporated and differences in test size are compensated.

The confidence intervals were computed using the standard normal-approximation method (Mood et a1. 1974). For a 95\% confidence interval, the following equation is used:

$P\left[E F F_{S C}-1.96 \sqrt{\operatorname{var}\left(E F F_{S C}\right)} \leq \operatorname{true}\left[E F F_{S C}\right] \leq E F F_{S C}+1.96 \sqrt{\operatorname{var}\left(E F F_{S C}\right)}\right]=.95$

Here EFFSC indicates our estimate while true [EFFSC] indicates the true or actual value of screen efficiency. EFFSC is a binomial proportion, and the form for its variance is EFFSC $\left(1-E F F_{S C}\right) / N$. However, because we used efficiencies (EFFip. EFFnc. EFFnr) in the computation of EFFsc with their own inherent errors. these errors must be propagated and incorporated into the variance of EFFSC. If EFFncr is defined to be the combined catch-andretain efficiency (EFFnc $\times$ EFFnr), then the variance of EFFsC is

$$
\begin{aligned}
\operatorname{var}\left[E F F_{S C}\right]= & \left(\frac{\partial E F F_{S C}}{\partial E F F_{n c r}}\right)^{2} \operatorname{var}\left[E F F_{n c r}\right]+\left(\frac{\partial E F F_{S C}}{\partial E F F_{i p}}\right)^{2} \operatorname{var}\left[E F F_{i p}\right] \\
& +\left(\frac{\partial E F F_{S C}}{\partial X_{n e t}}\right)^{2} \operatorname{var}\left[X_{n e t}\right]
\end{aligned}
$$

where all variables are as previously defined. This formula is the first term of a Taylor's series expansion (Holman 1971). Second and higher-order effects have been neglected. We assumed that EFFip. EFFncr, and $x_{n e t}$ are independent of each other. which is reasonable in this case.

The variances of EFFip and EFFncr were computed by assuming them to be binomial proportions and using the appropriate $N$ for the section in the EFF(1-EFF)/N formula as stated above. In the case of EFFncr. variances were computed individually for EFFnc and EFFnr and propagated throughout. The variable $x_{\text {net }}$, the number of fish caught in the nets from those that were released upstream of the screens, is distributed binomial (N.EFFsC). making its variance equal to $\left.\operatorname{NEFFSC}_{S}\left(1-E F F_{S C}\right)\right]$. 


\section{RESULIS}

At Toppenish Creek. fish that passed through the bypass system were not descaled or killed, and moved out of the forebay of their own volition. The angled rotary-drum screen design at Toppenish Creek. Wapato, and Sunnyside prevented most fish from entering the canal downstream of the screens. Improperly installed or maintained side and bottom seals will allow fish to swim through the screen facility.

Data for Toppenish Creek. Wapato, and Sunnyside, in 1988, are presented as they relate to the objectives of each phase outlined in the work plan in Appendix A. A detailed summary of catch data, estimates for percent of test fish descaled or killed, and estimates of screen efficiency are presented in Appendix B.

\section{PHASE I TESTS}

Phase I tests were designed to evaluate components within the fish diversion system other than the rotary drum screens. The Toppenish Creek fish bypass system contains no structures other than the drum screens: therefore, no Phase I tests were conducted. Phase I tests were conducted at Sunnyside during 1985 (Neitzel et al. 1985). Phase I tests have not been conducted at Wapato (Neitzel et al. 1988) because fish are not. descaled as they move from the trash racks to the fish return pipe.

\section{PHASE II TESTS}

Phase II tests evaluate the effects on fish of either the entire fish bypass system irom the trash racks through the fish return pipe (Phase Ila) or specific components of the fish return system (Phase IIb). During 1988 we conducted Phase II a and IIb tests at Toppenish Creek. Phase II tesis were completed at Sunnyside in 1985 (Neitzel et al. 1985) and at Wapato in 1987 (Neitzel et a1. 1988). At Toppenish Creek, we released fish at the trash racks and captured them before they entered the fish return pipe. In addition to evaluating fish descaling and mortality. we estimated how long released fish remained in the roppenish creek screen forebay. We also tested the potential effects of passage through the fish return pipe.

Ebase La

Tests at the Toppenish Creek Screens were conducted in late March. Three groups of branded steelhead smolts were released behind the trash racks, one group of 250 fish was released during low canal flow (20 cfs), and groups of 255 and 250 fish were released during full canal flow (50 cfs). of 250 steelhead planted during low canal flow. 144 (58\%) were captured on the inclined plane in the fish return during the next $72 n$. The plane was 
not fished for $2 \mathrm{~h}$ during the day following the low flow release because the inclined plane became plugged with detritus when the canal flow was changed from 20 to 50 cfs. Of 505 steelhead released during full canal flow. $395(78 \%)$ were caught during the following $48 \mathrm{~h}$. A total of 539 test. fish were examined for descaling: only one fish $(0.2 \%)$ was descaled (Table 1). This rate was within the $95 \%$ confidence interval for the condition controls (Appendix B). None of the $143 \mathrm{ftsh}$ held for $96 \mathrm{~h}$ died.

Downstream movement of steelhead released for descaling evaluations was monitored each half-hour as the fish appeared on our sampling plane in the fish return. The rate and percent recovery for steelhead (Figure 8 and Table 2) indicate that salmonid smolts are not flushed from the Toppenish Creek screen forebay; rather, they move through the screen forebay of their own volition. The recovery rate was lower for steelhead released during low canal flow.

Phase IID

Because test fish were more easily captured at the flow control structure, the potential effect of passage through the fish return pipe was evaluated separately. Because this tested a specific component of the fish return system, results are presented with Phase IIb.

Thirteen groups of 10 steelhead each were released at the head of the Toppenish Creek Screens fish return pipe. Of 130 steelhead released, 106 were captured and evaluated for descaling; none of the fish were descaled (Appendix B).

\section{PHASE III TESTS}

Test fish were released during two canal flows at Toppenish Creek: 20 cfs, which represents canal flow during the early spring, and $50 \mathrm{cfs}$, representing canal flow during the major irrigation-withdrawal period. Fish were not descaled at either flow. Movement of steelhead smolts from

IABLE 1. Descaling and Mortality Data from Release and Capture Tests with Steelhead Oncorhynchus mykiss Smolts at the Toppenish Creek Fish Screening Facility, Spring 1988

\begin{tabular}{|c|c|c|c|c|c|c|c|}
\hline \multirow{2}{*}{$\begin{array}{l}\text { Canal } \\
\text { Flow } \\
\text { (cfs) }\end{array}$} & \multicolumn{4}{|c|}{ Number } & \multicolumn{2}{|c|}{ Percent } & \multirow{2}{*}{$\begin{array}{c}95 \% \\
\text { Confidence } \\
\text { Interval }\end{array}$} \\
\hline & Released & Captured & Descaled & Dead & Captured & Descaled & \\
\hline $\begin{array}{l}20 \\
50 \\
50 \\
\end{array}$ & $\begin{array}{l}250 \\
255 \\
250 \\
\end{array}$ & $\begin{array}{l}144 \\
199 \\
196 \\
\end{array}$ & $\begin{array}{l}0 \\
1 \\
0\end{array}$ & $\begin{array}{l}0 \\
0 \\
0\end{array}$ & $\begin{array}{l}57.6 \\
78.0 \\
78.4 \\
\end{array}$ & $\begin{array}{l}0.00 \\
0.50 \\
0.00\end{array}$ & $\begin{array}{l}0-2 \\
0-3 \\
0-2\end{array}$ \\
\hline Total & 755 & 539 & 1 & 0 & 71.4 & 0.19 & $0-1$ \\
\hline Wila & & 462 & 1 & 0 & - & 0.22 & $0-1$ \\
\hline
\end{tabular}




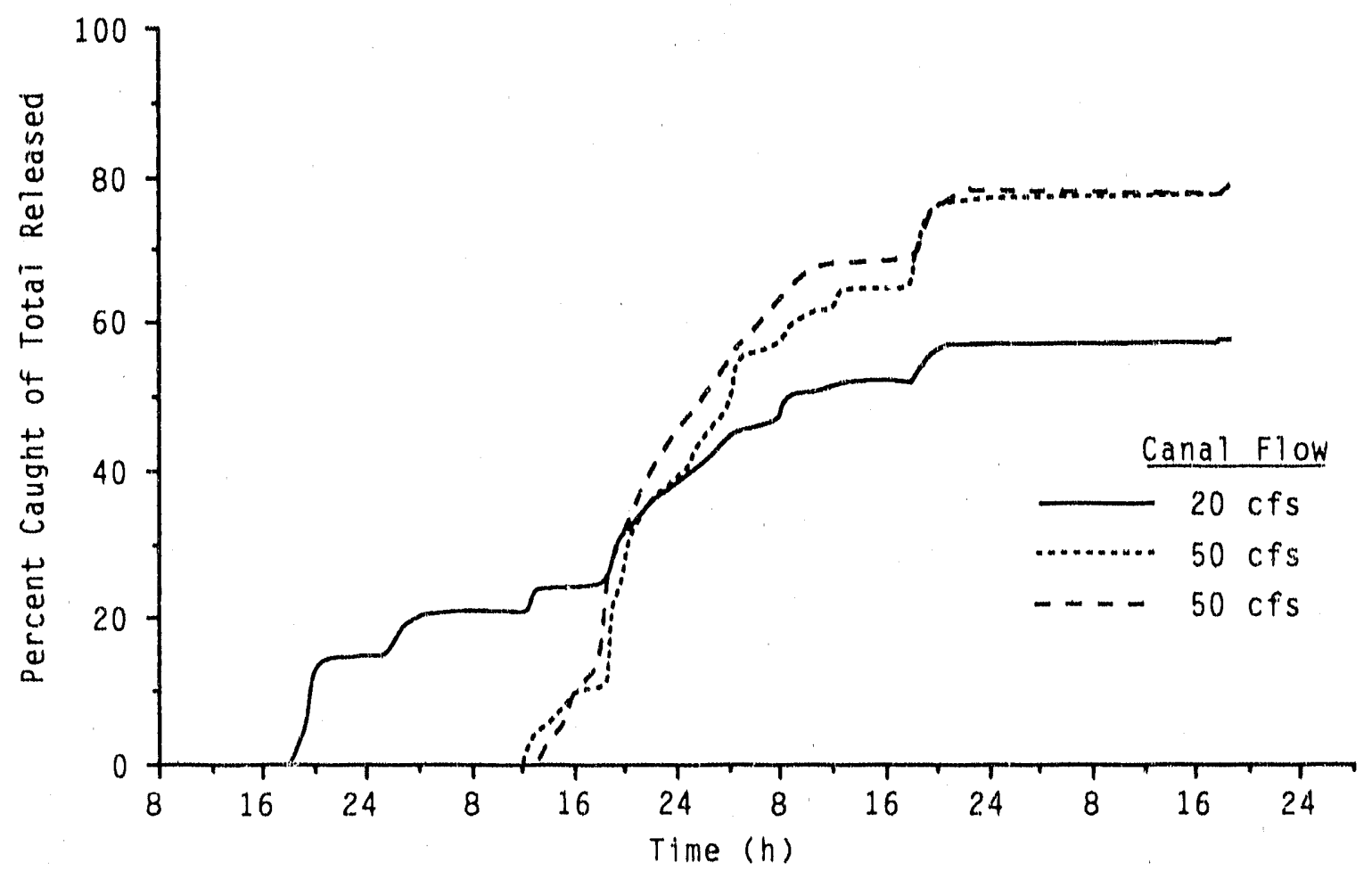

March 21 March 22 March 23 March 24

EIGURE 8. Movement of Steelhead Oncorhynchus mykiss Smolts Based on Capture of Release Fish at the Toppenish Creek Canal Fish Screening Facility. Spring 1988

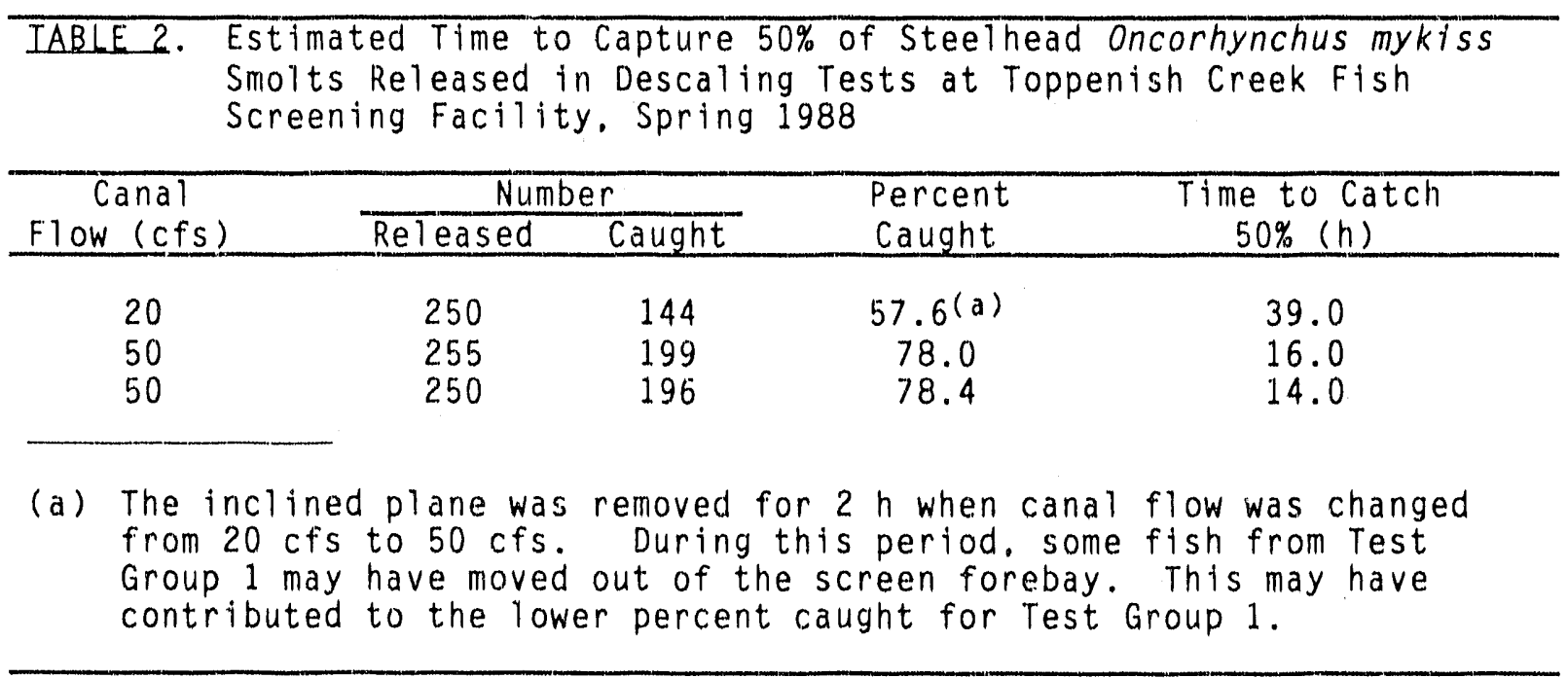


the screen forebay through the fish return was slower during low canal-flow condtitions.

\section{PHASE IY TESTS}

The inclined plane was used during release and capture tests to note the presence of predatory fish and the occurrence and condition of native salmonids. Drum screens were monttored to determine if fish were impinged. Ralnbow trout fingerlings were released at the Toppentsh creek screens and fall chinook salmon fingerlings were released at the Wapato and sunnyside screens to test for possible passage through, around, or over the rotary drum screens. Additionally, fyke nets were placed downstream of the wapato and Sunnyside screens while Yakima Indian Nation blologists released fall chinook salmon from rearing pens in the Wapato screen forebay.

Phase IVo. Toppentin creek Screens.

The only nattve salmonids captured during tests at the Toppenish creek Screens were juventle ralribow trout and/or steelhead. The $462 \mathrm{fish}$ we examined (average of $13 \mathrm{~cm} \mathrm{FL}$, range 7.0 to $19.5 \mathrm{~cm}$ ) did not have strong smoltification characteristics. Three adult steelhead kelts $(\sim 60 \mathrm{~cm} \mathrm{FL})$ were caught on the inclined plane, indicating that steelhead spawning occurs upstream of the Toppenish creek Diversion.

No predaclous fish other than rainoow trout/steelhead were caught at the Toppenish creek screens. Both the native rainbow trout and test fish that were released during descaling tests preyed on the smaller rainbow trout: that were released in the forebay for screen integrity tests (Phase IVb).

Phase IVt. Toppenish creek screens

A total of 3073 rainbow trout fry $(47.3 \mathrm{~mm} \mathrm{FL})$ were released in front of the screens and 900 were released in the mouth of fyke nets behind the screens to evaluate the effectiveness of angled rotary drum screens in preventing fish from entering the irrigation canal behind the screens (Table 3). Of 3073 fish released in front of the screens, 2373 (79\%) were recovered in the fish return and $11(0.4 \%)$ were recovered in the fyke nets. 2 behind screen 1 , and 9 fish behind screen 3 . Additionally, 6 native ratnbow trout $(8.5-19.6 \mathrm{~cm} F \mathrm{Fl})$ were caught in the fyke nets: 2 behind screen 1 , and 4 behind screen 3 . No fish were caught behind screen 2 except for net concrol fish. Of 900 rainbow trout released in the mouths of fyke nets behind the drum screens. 52\%. (58\%) were recovered from fyke nets, and $3 \%$ (4\%) were recovered on the inclined plane (Table 4).

Approximately $20 \%$ of the rainbow trout fry released in front of the screens were not recovered. Predation in the screen forebay by test fish and wild steelhead was conftrmed by examining the gut contents of fish captured on the inclined plane. Rainbow trout fry were not flushed from the Toppenish 


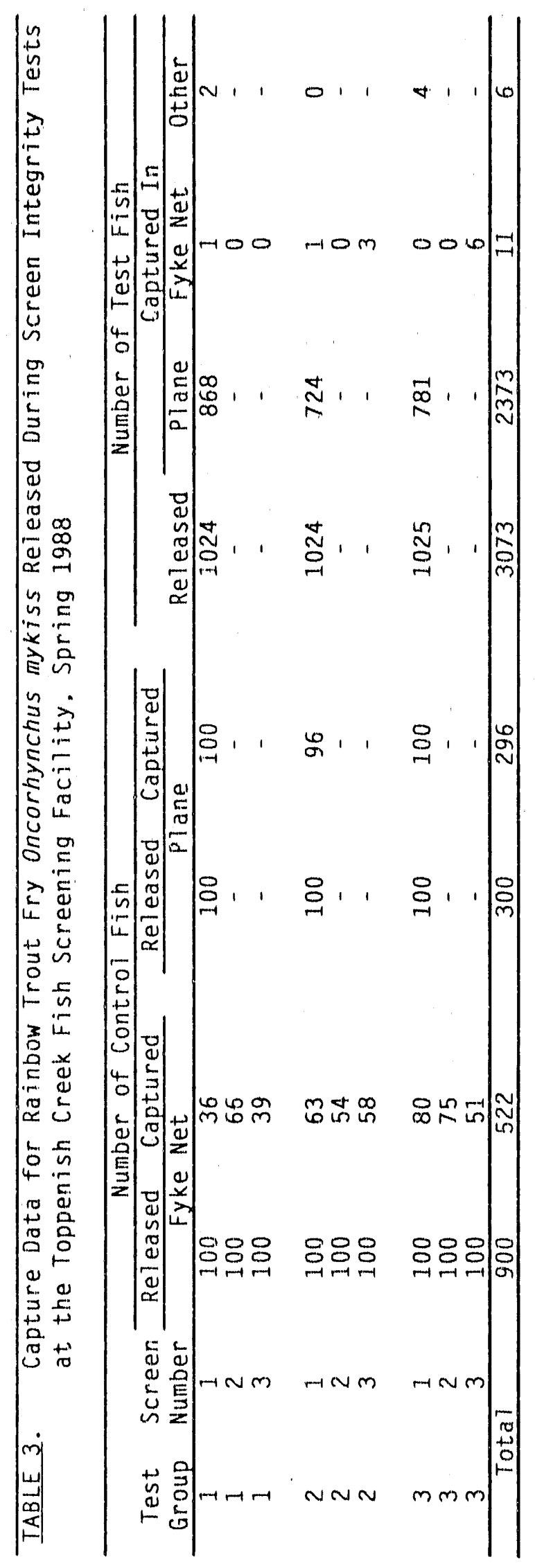


IABLE 4. Capture Efflciency of the Inctined Plane and Fyke Nets Used During Screen Integrity Tests at the Toppentsh Creek Fish Screening Facility. Spring 1988

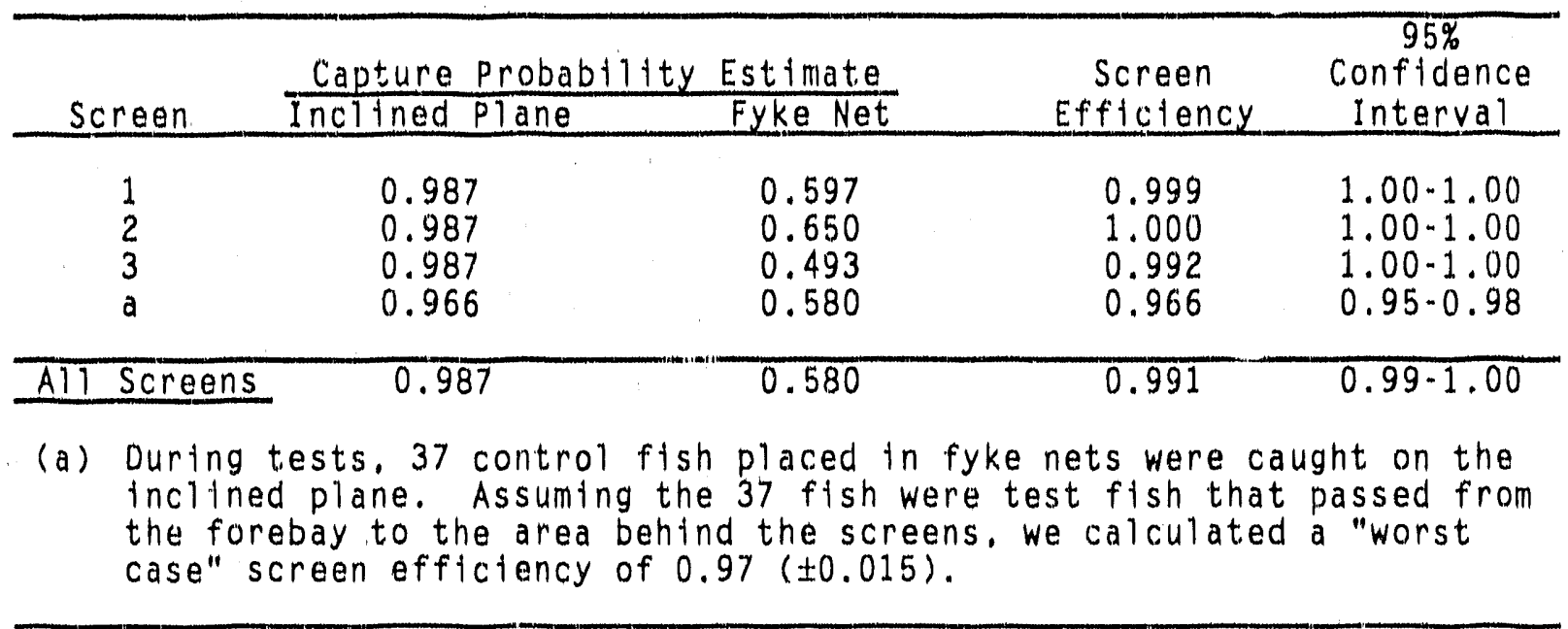

Creek Screen forebay (Table 5). Some, ish were captured on the inclined plane immediately after release. Most fish were recovered on the plane after sunset on the first night following their release (Figure 9). Few fish were captured after more than $24 \mathrm{~h}$ of release.

Phase IVa. Wapato Canal

Phase IVa observations were completed at the Wapato Screens in 1987 (Neitzel et a 1. 1987) and were not repeated. Some predatory fish (largemouth bass Micropterus salmoides. smallmouth bass M. dolomieui. northern squawfish Ptychochelius oregonensis) were caught during tests in 1987, although losses to predation were minimal. However, this year. massive numbers of hatchery-reared coho salmon 0 . kisutch released in early May were present in the Wapato screen forebay and preyed on the chinook salmon fry released during Phase IVb tests.

Phase IVb. Wapate Canal

A total of 8235 fall chinook salmon fry were released in screen integrity tests at the Wapato Screens (Table 6). Fish were released in front of the screens, in the intermediate and termiral fish bypasses, and in the mouths and cod ends of fyke nets positioned beinind the screens.

Of 500 fish released in the intermediate and terminal bypasses during the first three tests at Wapato Screens, 385 (77\% average, range $71 \%-85 \%$ ) were captured on the inclined plane. Of 100 fish released in the terminal bypass in the fourth test. 96 (96\%) were captured on the inclined plane. The difference in catch rate between the first three tests and the fourth test probably reflects predation on fall chtnook salmon by coho salmon 
IABLE 5. Estimated Time to Capture $50 \%$ of Rainbow Trout Oncorhynchus mykiss Fry Released in Screen Integrtty Tests at Toppentsh Creak Fish Screening Factlity. Spring 1988

\begin{tabular}{|c|c|c|c|c|}
\hline \multirow{2}{*}{$\begin{array}{l}\text { Tes. } \\
\text { Group }\end{array}$} & \multicolumn{2}{|c|}{ Number } & \multirow{2}{*}{$\begin{array}{l}\text { Percent } \\
\text { Caught }\end{array}$} & \multirow{2}{*}{$\begin{array}{c}\text { Time (h) to Catch } \\
50 \%\end{array}$} \\
\hline & Released & Caught & & \\
\hline $\begin{array}{l}1 \\
2 \\
3\end{array}$ & $\begin{array}{l}1024 \\
1024 \\
1025\end{array}$ & $\begin{array}{l}868 \\
724 \\
781 \\
\end{array}$ & $\begin{array}{l}84.8 \\
70.7 \\
76.2 \\
\end{array}$ & $\begin{array}{l}4.0 \\
9.0 \\
4.0 \\
\end{array}$ \\
\hline
\end{tabular}

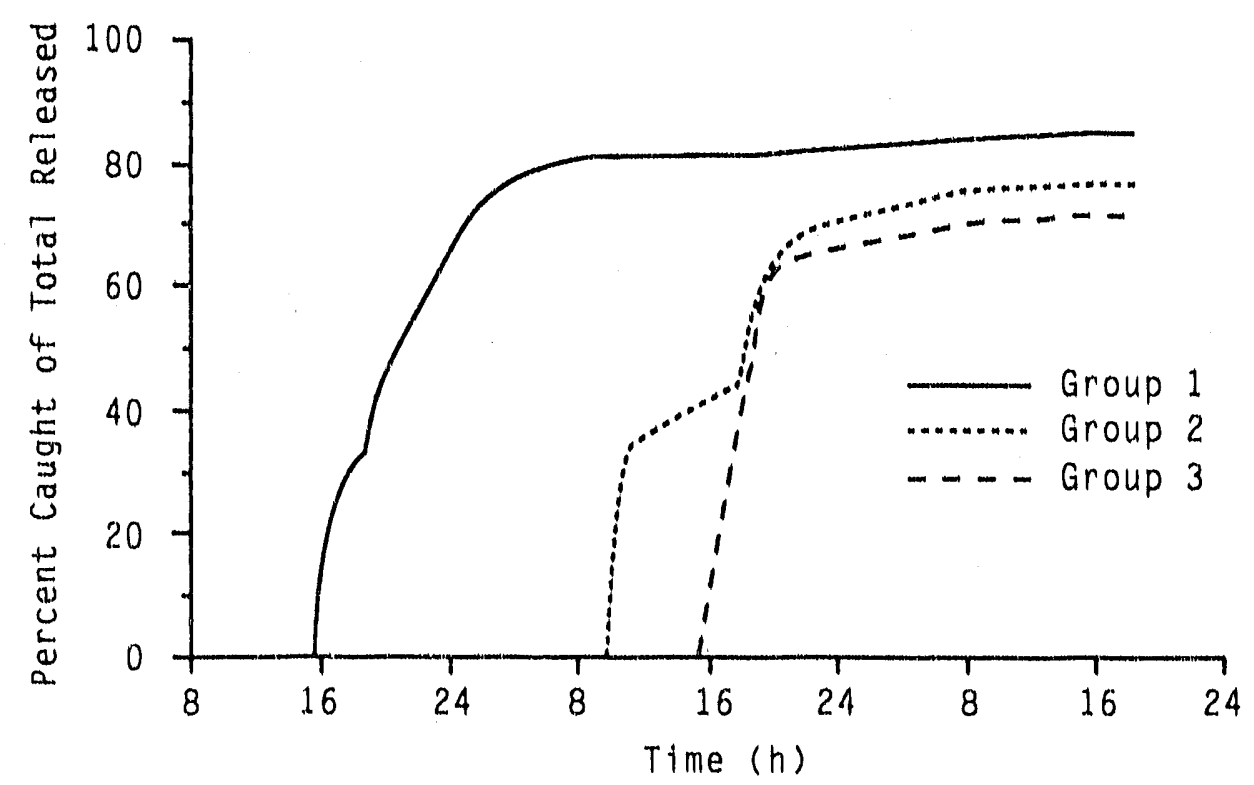

March 22 March $23 \quad$ March 24

EIGURE 9. Movement of Rainbow Trout Fry Oncorhynchus mykiss Based on Capture of Released Fish in the Bypass During Screen Integrity Tests at the Topperish Creek Canal Fish Screening Facllity. Spring 1988

smolts in earlier tests. Catch efflctency of fyke nets varled from $79 \%$ to $97 \%$, and net retention effictency ranged from $85 \%$ to $90 \%$ (Table 7 ).

A large number of salmonid smolts, primartly coho salmon. were present in the Wapato screen forebay during our tests. When major movement through the fish return commenced after sunset. fish collection in the bypass was terminated and the inclined plane was removed from the return. Fyke nets were fished only until $1900 \mathrm{~h}$ during the first test but were fished overnight in the second., third and fourth tests.

Of 6235 fish released in front of the screens, 4380 (70\% average, range $51 \%$ to $92 \%$ ) were caught in the fish return, and $43(0.7 \%)$ were caught in the 


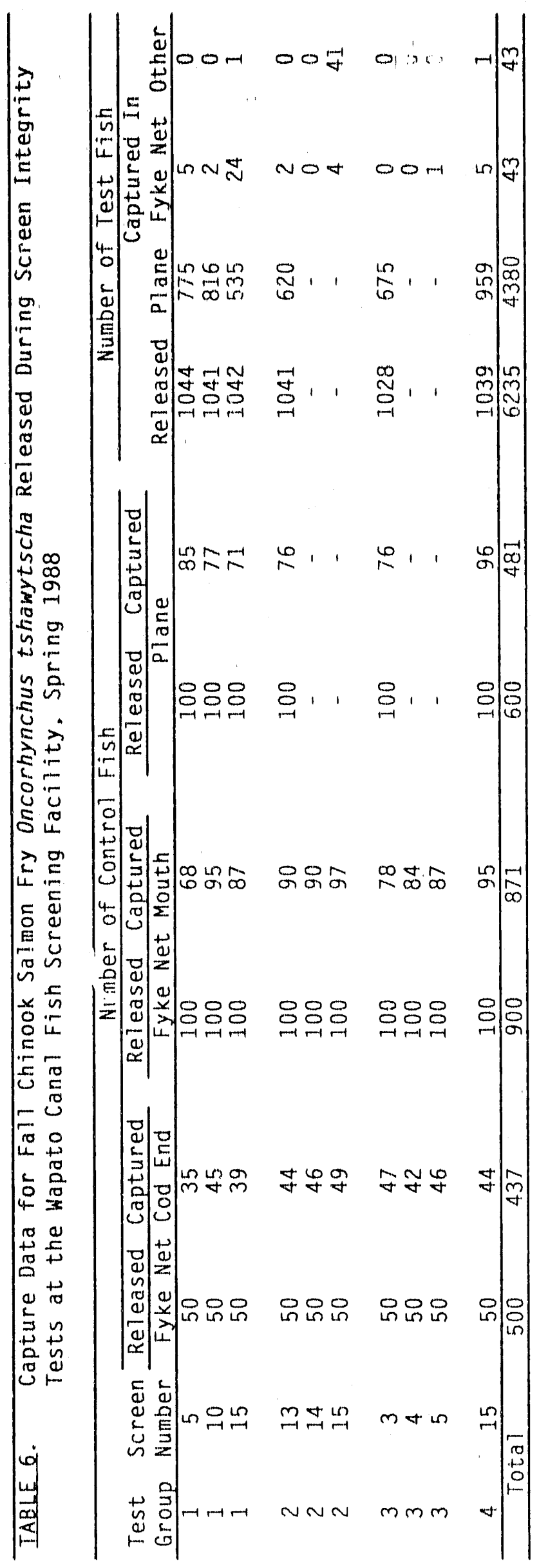




\section{IABLE 7. Capture Efficiency of Inclined Plane and Nets and Retention Efflciency for Fyke Nets Used During Screen Integrity Tests at the Wapato Canal Flsh Screentng Factlity. Sprtno 1988}

\begin{tabular}{|c|c|c|c|c|c|}
\hline \multirow[b]{2}{*}{$\begin{array}{c}\text { Screen } \\
\text { Sectton (a) }\end{array}$} & \multicolumn{3}{|c|}{ Probability Estimate } & \multirow[b]{2}{*}{$\begin{array}{c}\text { Screen } \\
\text { Efflciency }\end{array}$} & \multirow{2}{*}{$\begin{array}{c}95 \% \\
\text { Confidence } \\
\text { Interval }\end{array}$} \\
\hline & $\begin{array}{c}\text { Plane } \\
\text { Capture }\end{array}$ & $\begin{array}{c}\text { Net } \\
\text { Capture }\end{array}$ & $\begin{array}{c}\text { Nat } \\
\text { Retention }\end{array}$ & & \\
\hline $\begin{array}{c}1-5 \\
6-10 \\
11-15 \\
15 \\
1-15\end{array}$ & $\begin{array}{l}0.805 \\
0.770 \\
0.810 \\
0.960 \\
0.802\end{array}$ & $\begin{array}{l}0.793 \\
0.950 \\
0.918 \\
0.950 \\
0.968\end{array}$ & $\begin{array}{l}0.850 \\
0.900 \\
0.888 \\
0.880 \\
0.874\end{array}$ & $\begin{array}{l}0.995 \\
0.998 \\
0.984 \\
0.994 \\
0.991\end{array}$ & $\begin{array}{l}0.99-1.00 \\
0.99-1.00 \\
0.98-0.99 \\
0.99-1.00 \\
0.99-1.00\end{array}$ \\
\hline
\end{tabular}

(a) Screens are numbered from the upstream (NUMBER 1) to the downstream screen nearest the separation chamber (NUMBER 15).

fyke nets behind the screens. Other salmonids were also caught in the fyke nets. Forty coho salmon smolts were caught behind screen 15 in the second test (Table 6).

Fall chinook salmon fry released in the fish bypasses were not flushed as rapidly through the separation chamber and into the fish return slot (Figure 10. Table 8) as was observed during integrlty tests conducted at the Wapato Screens in 1987 (Neftzel et al. 1987). Lower bypass flows caused by an inoperable vertical traveling screen in the separation chamber may have contributed to the slower movement rate and lower fish recovertes.

In addition to the integrity tests, we monitored screens 13 - 15 at Wapato with fyke nets during release of the Yakima Indian Nation's (YIN's) fall chinook salmon from net pens in the Wapato forebay. About 200.000 salmon were released on the evening of May 18. An additional 50.000 fall chinook salmon were released earlier in the afternoon before our fyke nets were in place. The nets were fished overnight and removed about. $0700 \mathrm{~h}$ May 19. The inclined plane was not used during the monitoring.

Most fall chinook salmon released from the pens moved out of the screen forebay overnight. A total of 190 fall chinook salmon ( $80 \mathrm{~mm} F L$ ) were caught in our fyke nets (Table 9). Some recovered fish were badly cut and crushed. Screens 13 and 14 prevented fish from passing into the canal behind the drum screens. The 185 fish recovered from fyke nets behind screen 15 represent less than $0.1 \%$ of the total number of fish released.

sunyside cand phase IVb

A total of 6185 fall chinook salmon fry were released at the sunnyside screens (Table 10) in front of the screens, in the intermediate and terminal fish bypasses, and in the mouths of fyke nets behind the screens. of 400 fish reiedsed in the intermediate and terminal bypases. 317 (79\%) 
Test 1

Screens $5,10,15$
Test 2 Screens $13-15$
Test 3 Screens $3-5$
Test 4 Screen 15
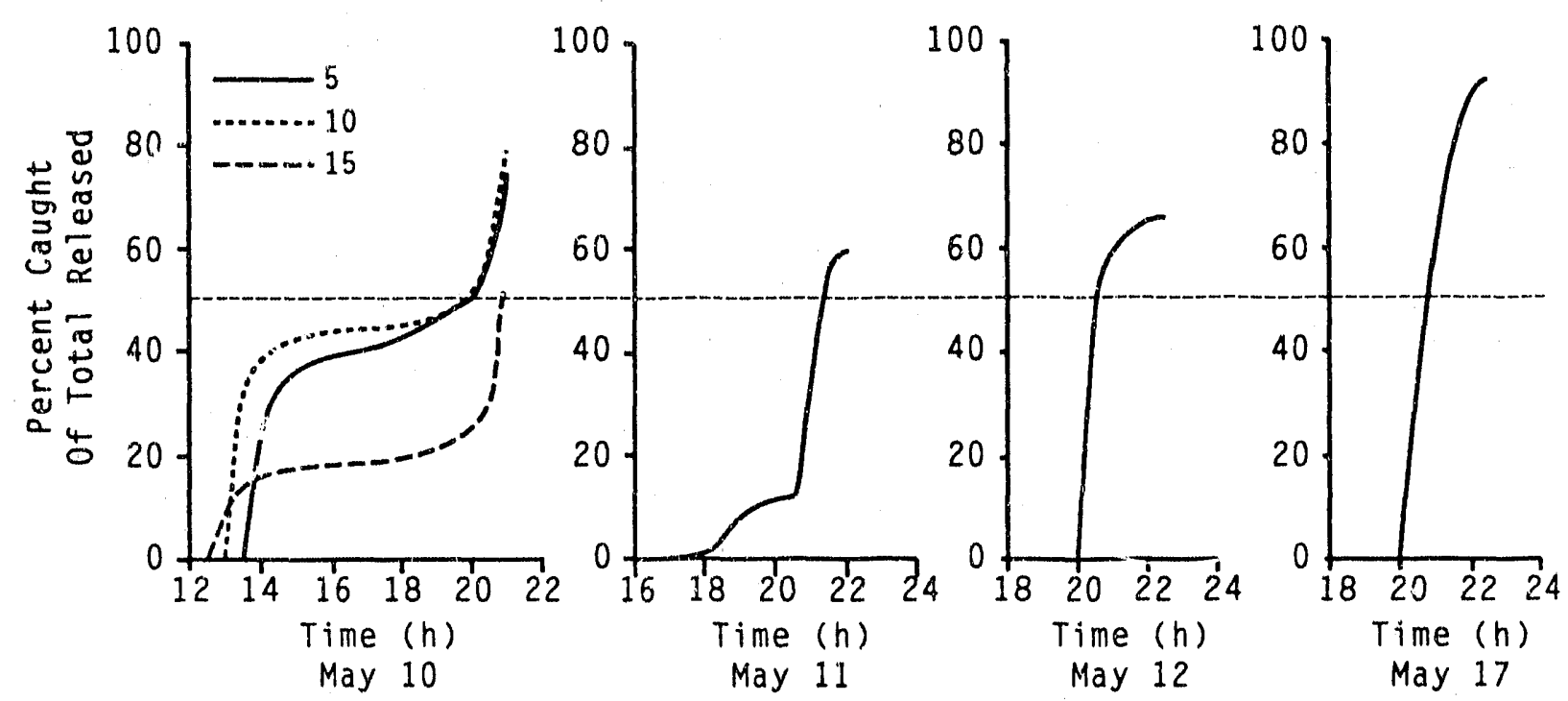

EIGURE 10. Movement of Fall Chinook Salmon Oncorhynchus tshawytscha Fry Based on Capture of Released Fish in the Bypass During Screen Integrity Tests at the Wapato Canal Fish Screening Facility. Spring 1988

\section{IABLE 8. Estimated Time to Capture $50 \%$ of Fall Chinook Salmon Oncorhynchus tshawytscha Fry Released in Screen Integrity Tests at the Wapato Fish Screening Facility. Spring 1988}

\begin{tabular}{|c|c|c|c|c|c|}
\hline \multirow{2}{*}{$\begin{array}{l}\text { Test } \\
\text { Group }\end{array}$} & \multirow[b]{2}{*}{ Screens } & \multicolumn{2}{|c|}{ Number } & \multirow{2}{*}{$\begin{array}{l}\text { Percent } \\
\text { Caught } \\
\end{array}$} & \multirow{2}{*}{$\begin{array}{c}\text { Time to Catch } \\
50 \%(h)\end{array}$} \\
\hline & & Released & Caught & & \\
\hline $\begin{array}{l}1 \\
1 \\
1 \\
2 \\
3 \\
4\end{array}$ & $\begin{array}{c}5 \\
10 \\
15 \\
13-1.5 \\
3-5 \\
15\end{array}$ & $\begin{array}{l}1044 \\
1041 \\
1042 \\
1041 \\
1028 \\
1039\end{array}$ & $\begin{array}{l}775 \\
816 \\
535 \\
620 \\
675 \\
959\end{array}$ & $\begin{array}{l}74.2 \\
78.4 \\
51.3 \\
59.6 \\
65.7 \\
92.3\end{array}$ & $\begin{array}{l}6.5 \\
7.0 \\
7.5 \\
4.5 \\
0.5 \\
1.0\end{array}$ \\
\hline
\end{tabular}

were captured in the fish return. Of 1599 fish planted in the mouths of fyke nets. 1310 ( $82 \%$ ) were recovered from the nets (Table 11 ).

Coho salmon smolts were also presert at the Sunnyside Screens during our tests. When major movement of salmonid smolts commenced after sunset, fish collection in the fish return was terminated and the inclined plane was removed. Fyke nets were fished overnight for all tests. Of $4186 \mathrm{fish}$ released in front of the screens, 3273 (78\% average, range $71 \%$ - $85 \%$ ) were caught in the fish return, and $60(1.4 \%)$ were caught in the fyke nets 


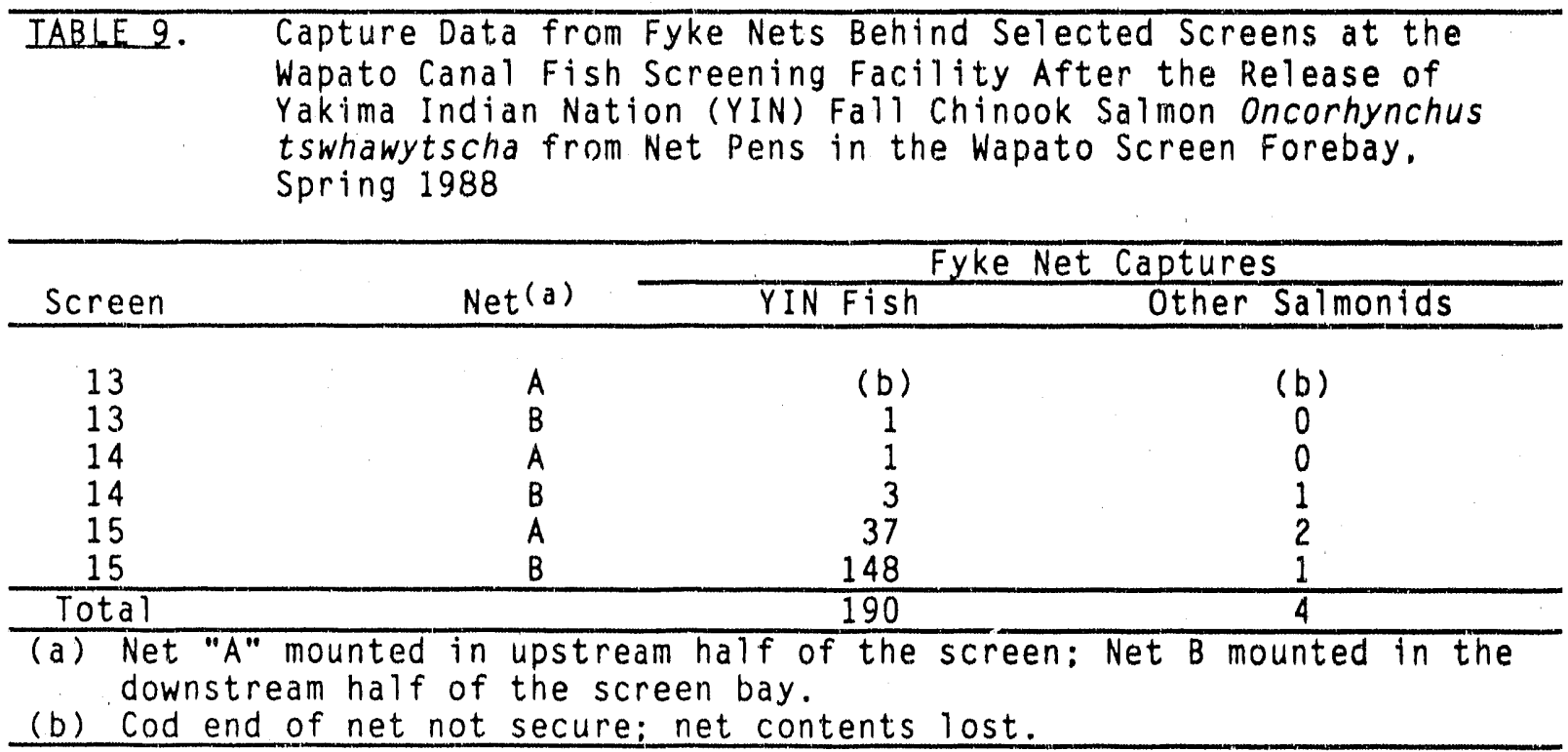

behind the screens. Eleven salmonids, including some of our test fish that were not identifiable. 1 coho and 2 chinook salmon smolts, were also caught in fyke nets behind the drum screens.

Fall chinook salmon fry released in the fish bypasses were flushed rapidly through the separation chamber and into the fish return slot. All fish released in the bypasses were recovered within 30 minutes of release. Test fish released in front of the screens also moved quickly through the bypass system (Figure 11 and Table 12). Most fish were collected on the inclined plane during the first hour after release: however. small numbers were caught throughout the period when the inclined plane was monitored.

We also monitored screens 8 and 17 at the Sunnyside Screens with fyke nets during the release of YIN's fall chinook salmon from net pens in the Wapato Screens forebay. About 200.000 salmon were released on the evening of May 18. An additional 50,000 salmon were ruleased earlier in the afternoon before our fyke nets were in place. The fyke nets were fished overnight and removed the next morning. The inclined plane was fished until $2100 \mathrm{~h}$ to determine the first arrival of released fish at Sunnyside Screens. The first arrival of fall chinook salmon occurred about $2 \mathrm{~h}$ after release at the Wapato Screens. A total of 185 fall chinook salmon ( $80 \mathrm{~mm} \mathrm{FL}$ ) were caught in fyke nets (Table 13). Some fish were badly cut and crushed. Screen 8 prevented passage of fish into the canal behind the drum screens. The 183 fish recovered from fyke nets behind screen 17 represent $<0.1 \%$ of the total released. 


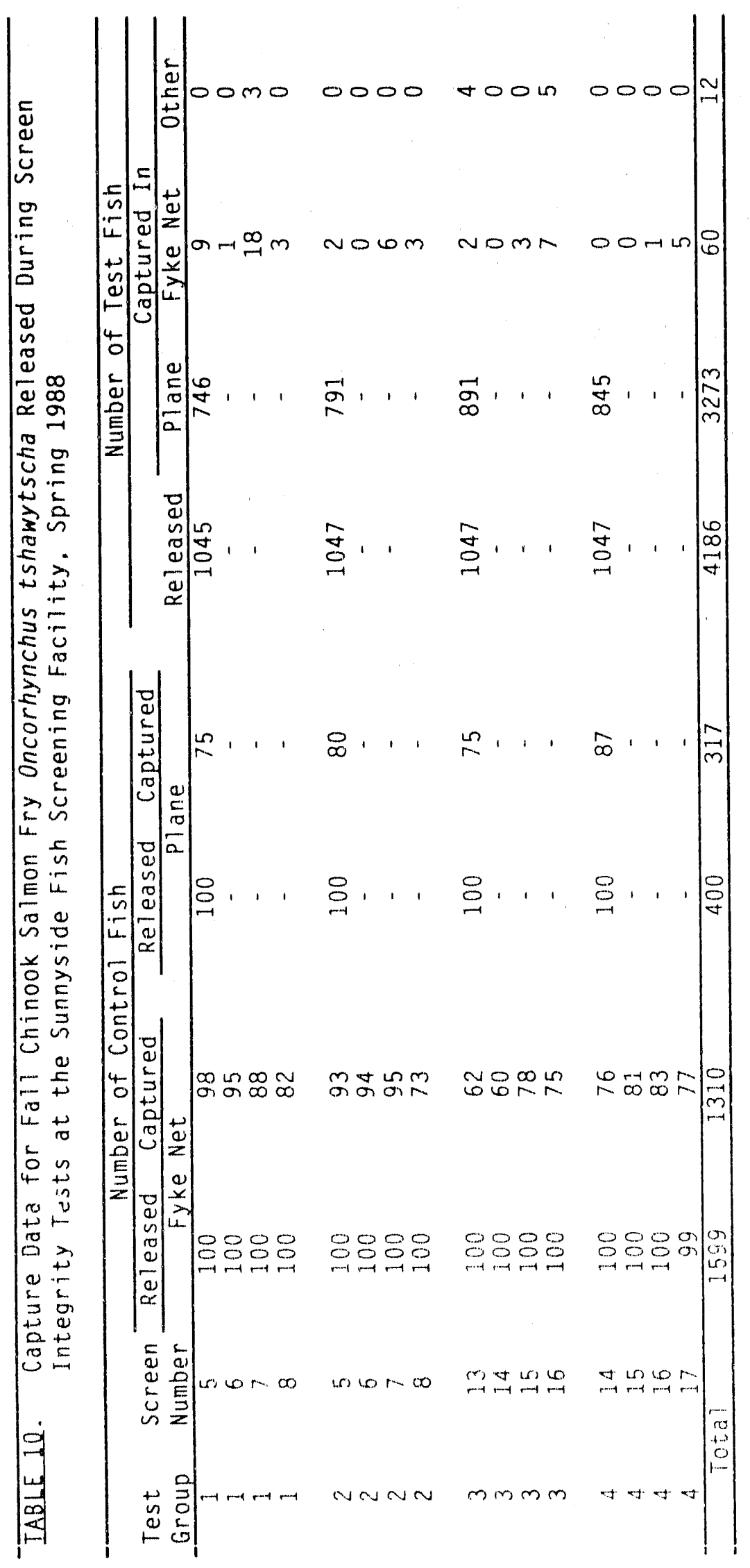




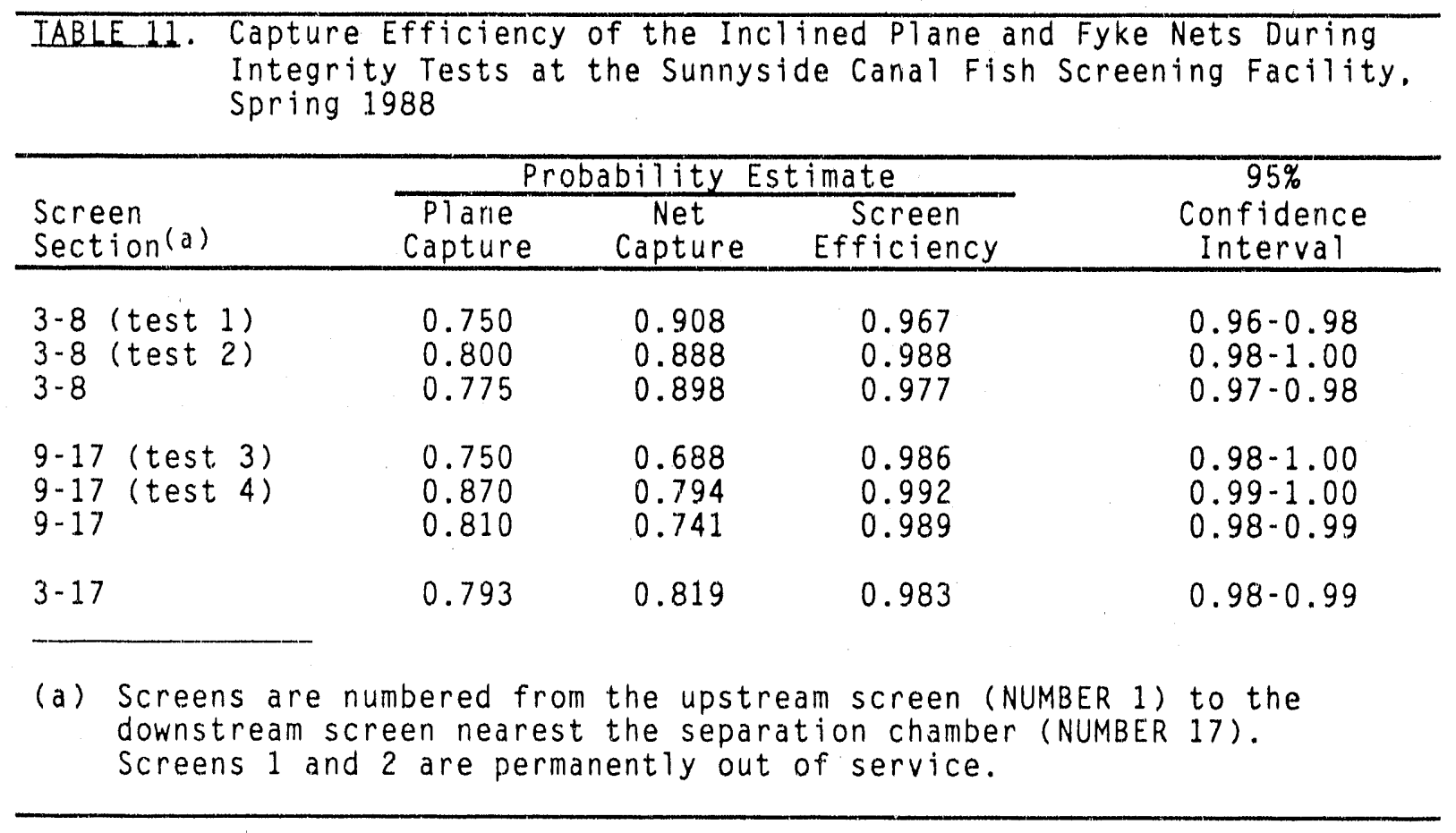
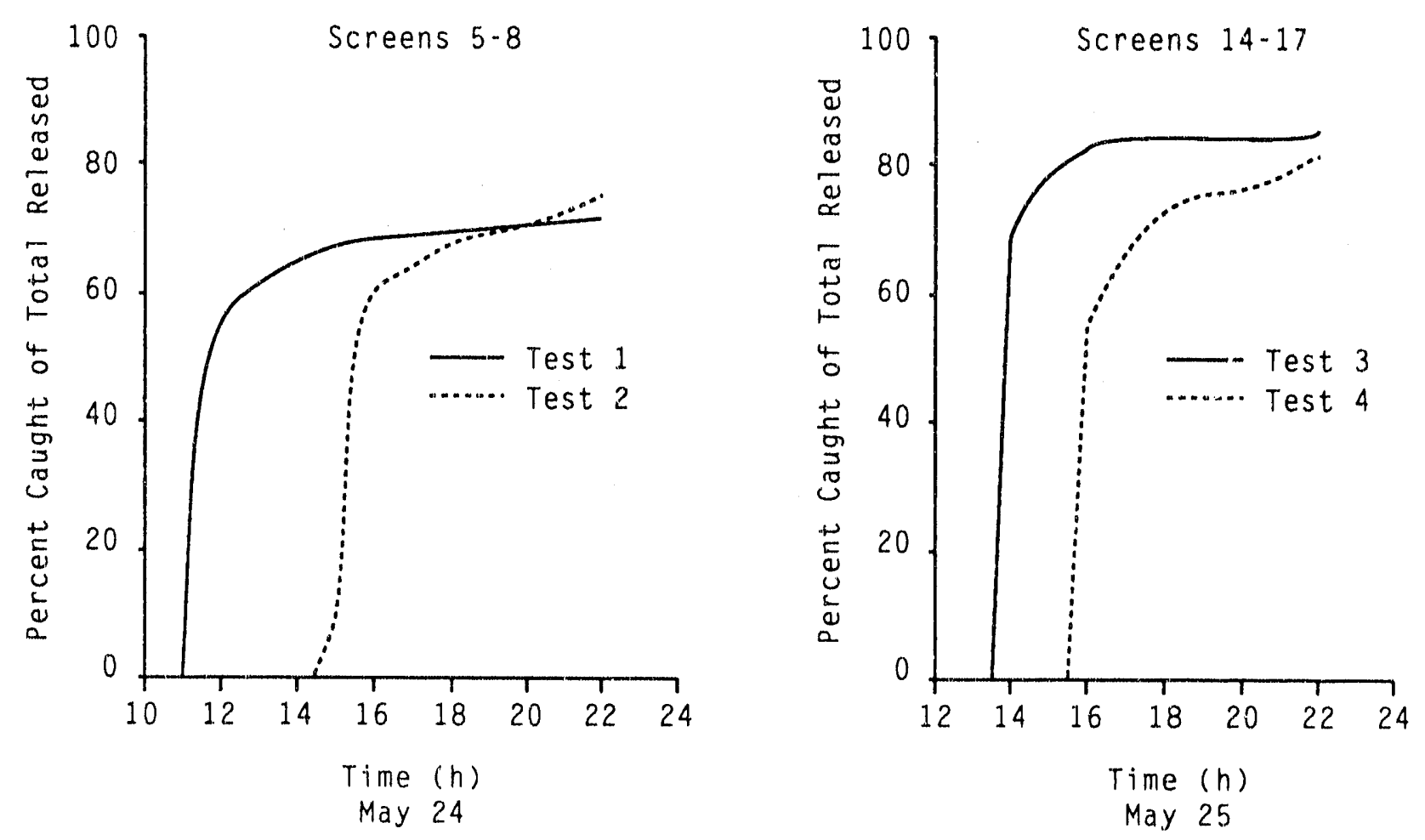

EIGURE 11. Movement of Fall Chinook Salmon Oncorhynchus tshawytscha Fry Based on Capture of Released Fish in the Bypass During Screen Integrity Tests at the Sunnyside Canal Fish Screening Facility. Spring 1988 


\begin{tabular}{|c|c|c|c|c|}
\hline IABLE 12. & \multicolumn{4}{|c|}{$\begin{array}{l}\text { Estimated Time to Capture } 50 \% \text { of Fall Chinook Salmon } \\
\text { Oncorhynchus tshawytscha Fry Released in Integrity Tests at } \\
\text { the Sunnyside Fish Screening Facility. Spring } 1988\end{array}$} \\
\hline Test & \multicolumn{2}{|c|}{ Number } & Percent & Time $(h)$ to Catch \\
\hline Group & Released & Caught & Caught & $50 \%$ \\
\hline $\begin{array}{l}1 \\
2 \\
3 \\
4\end{array}$ & $\begin{array}{l}1045 \\
1047 \\
1047 \\
1047\end{array}$ & $\begin{array}{l}746 \\
791 \\
891 \\
845 \\
\end{array}$ & $\begin{array}{l}71.4 \\
75.5 \\
85.1 \\
80.7\end{array}$ & $\begin{array}{r}1.0 \\
1.0 \\
<0.5 \\
<0.5\end{array}$ \\
\hline
\end{tabular}

IABLE 13.
Sapture Data from Fyke Nets Behind Selected Screens at the
Sunnside Canal Fish Screening Facility After Release of
Yakima Indian Nation (YIN) Fall Chinook Salmon Oncorhynchus
tshaws Sha Fingerlings from the Wapato Screens Forebay.
Spring 1988

\begin{tabular}{cccc}
\hline $\begin{array}{c}\text { Screen } \\
\text { Number }\end{array}$ & Net (a) & FIN Fish & Other Salmon(b) \\
\cline { 3 - 4 } 8 & A & 2 & 2 \\
8 & $B$ & 0 & 0 \\
17 & $A$ & 26 & 2 \\
17 & $B$ & 157 & 9 \\
Total & 185 & 9 \\
(a) Net A is the top net. Net B is the bottom net (Figure 7). \\
(b) Includes smolt-sized and 0-age salmonids.
\end{tabular}




\section{DISCUSSION}

Screening facilities in the Yakima River Basin are designed to direct fish that have been diverted from the river and into irrigation canals back to the river without killing or injuring them or delaying their migration. This section discusses data collected at Toppenish Creek. Wapato, and Sunnyside during 1988, and relates the 1988 data to those collected at Sunnyside, Toppenish/Satus, Richland, and Wapato (Neitzel et al. 1986, 1987. 1988) from 1985 through 1987.

\section{EISH SURVIVAL AT SCREENING EACILIIIES}

Based on release and capture data at five screening facilities, fish are not descaled or killed during passage in front of the rotary drum screens or through the fish bypass systems. As in previous descaling evaluations at the Sunnyside, Richland. Toppenish/Satus, and Wapato screens, the condition of test fish after passing through the bypass system at Toppenish creek is similar to that of control fish.

\section{POTENTIAL FOR PREDATION AT SCREENING FACILITIES}

Screening facilities could affect predator/prey relationships if the screens concentrate prey or increase the exposure of prey to predators because of stress, injury, or delayed migration. Based on samples we have collected. loss to predation by native species does not appear to occur. However, hatchery-released salmonids diverted into the screen forebay may increase predation pressure at screen sites. We observed hatchery reared steelhead smolts feeding on our test fish at Toppenish Creek, and coho salmon smolts feeding on our test fish at Wapato and Sunnyside. Low bypass flows may prolong smolt residence time in screen forebays, thus increasing predation pressure on salmonid fry.

\section{Ioppenish creek Screens}

Some predation was observed at the Toppenish Creek Screens following release of 0 -age rainbow trout fry in the forebay. Juvenile rainbow trout and steelhead. primarily fish released during descaling evaluation, were present in the forebay and opportunistically fed on the smaller fry. predation. therefore, appeared to be related to the artificial and temporary predator-prey population structure created by the release of test fish.

Emergence of salmonid alevins in Toppenish Creek may commence later than the peak steelhead smolt migration. No native 0 -age rainbow trout fry were captured during 4 days of sampling at the Toppenish Creek Screens. Regardless, the natural predator-prey population structure in the screen 
forebay should be simllar to that in Toppenish Creek because fish movement through the forebay is not impaired when adequate bypass flows are provided.

\section{Wapate Screens}

Coho salmon released in the Yakima River upstream of the Wapato Screens were present in the forebay and preyed on fall chinook salmon that we released on May 10 through 13. Predation occurred in front of the screens as well as in the fish bypass system. We conclude this from the following. During 1987. more than $90 \%$ of the test fish released into the bypass and in the forebay were caught on the plane. In similar tests conducted during 1988. With coho smolts in the forebay. less than $80 \%$ of the test fish were caught on the plane (Table 14). After the coho smolts were "flushed" out. of the forebay: more than $90 \%$ of the test fish were caught. An inoperable traveling screen in the separation chamber, during 1988 tests, resulted in bypass flows that were less than those recommended in the operating criteria. Flow through the fish return pipe was increased to more than 35 cfs from May 13 through 17 . The increased flow was provided to compensate for the reduced bypass flow through the traveling screens and to "flush" the coho salmon from the screen forebay. Few coho salmon smolts were captured in a test conducted on May 17, and the capture rate for test fish was simflar to rates observed in 1987 tests.

TABLE 14. A comparison of capture efficiency data during screen efficiency tests at the Wapato Canal Fish Screening Facility. spring 1987 and 1988

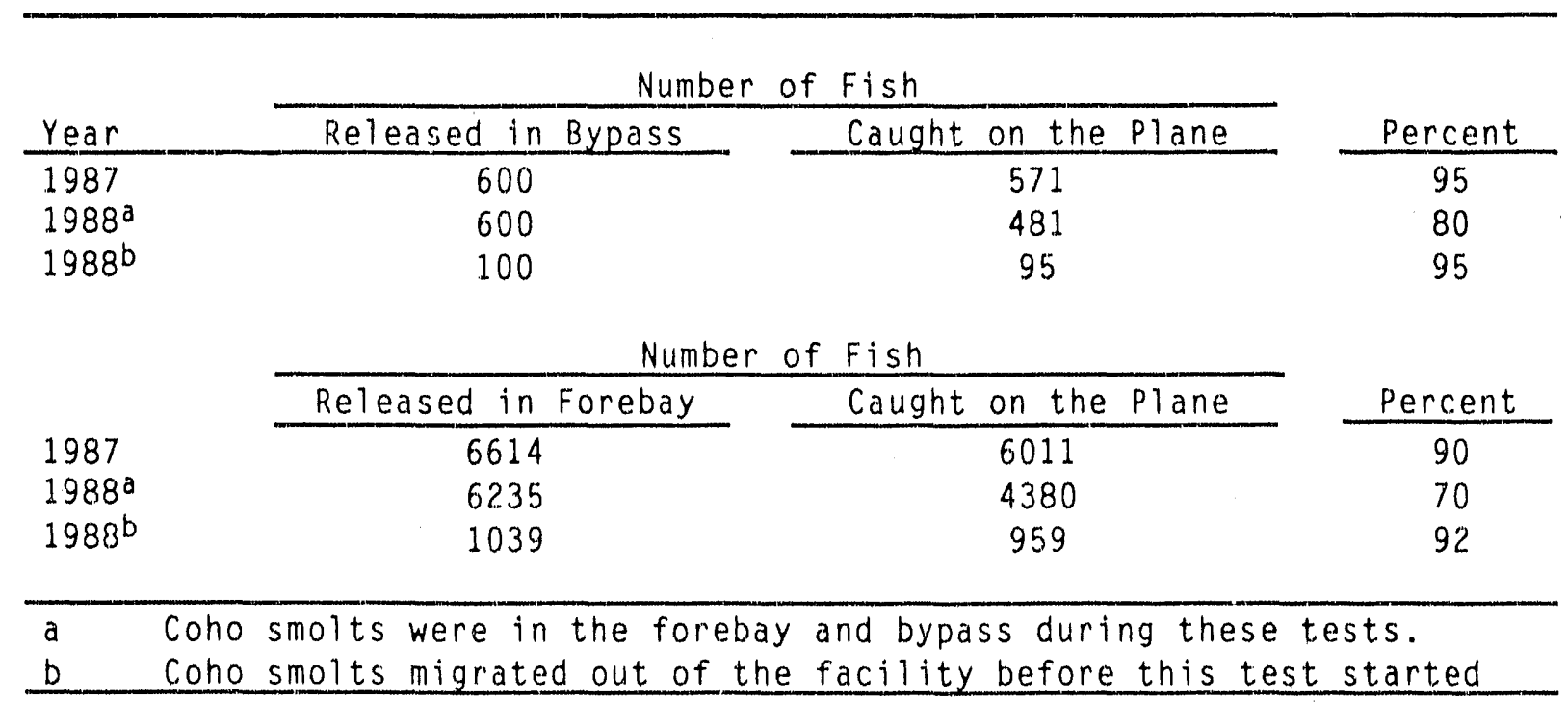




\section{Sunnyside Screens}

Few predactous fish were observed at the Surnyside Screens on May 24 through 26 and fewer salmonid smolts were observed than during tests at the Wapato screens. Although no predatory activity was apparent in the screen forebay, the capture rate for test fish in the fish return was lower than expected based on the catch rate of test fish at the Wapato Screens in similar tests. Fallure to completely seal the primary fish return so that all bypass water crossed our inclined plane (1.e.. reduced plane efficlency), and not predation, may have resulted in lower capture rates.

\section{POTENTIAL FOR FISH DELAY AT SCREENING FACILITIES}

One objective of the angled screen facility design is to provide a facility that safely and rapidly returns fish from the diversion canal to the river (Easterbrooks 1984). Although, fish are not "flushed" from the screen forebay back to the river, the screening factlities do not impede voluntary movement and migration under normal operating conditions. Conversely. inadequate bypass flows resulting from improper operation, inoperable components in the bypass system. low canal flows or forebay elevations, or blockages in the fish return can impair fish movement through the bypass system and contribute to migration delays.

Flow through the fish return pipe at Toppentsh Creek Screens was severely restricted before we initiated testing. Normal bypass flows were not attainable because the fish return slot was backed up with water. The fish return was plugged by boulders that had washed into the mouth of the pipe during high stream flows in winter. The creek bed is unstable at the end of the fish return pipe, and the pipe may become plugged again. Besides restricting water flow, a partially plugged pipe would probably injure fish. No injuries were observed for fish passing through the unobstructed pipe.

An inoperable traveling screen in the separation chamber resulted in low bypass flows during integrity tests at the Wapato screens. With one screen plugged, bypass flows were reduced so that the inclined plane in the fish return could be operated effectively. Lower bypass flows contributed to slower movement through the fish separation chamber. lower fish capture in the return, and increased predation of our test fish by hatchery released coho salmon smolts in the screen forebay and separation chamber.

\section{EISH PASSAGE THROUGH QR OYER ROTARY DRUM SCREEHS}

The designed sweeping/approach velocity ratio helps guide fish into the fish bypass. and screen mesh openings $(3.18 \mathrm{~mm}, 1 / 8 \mathrm{in.}$ ) are small enough to prevent fish passage through the drum screens. Tests were conducted at 
the Toppentsh Creek. Wapato, and Sunnyside Screens to determine if any fish were tmpinged by or passed through the screens.

\section{Ioppenish creek Screens}

No ftsh passed over the drum screens at the Toppentsh Creek: some fish. including two smolt-size rainbow trout, were caught in fyke nets behind two of the three screens. No native fish or fish released in front of the screens were captured in the fyke net behind screen 2. Faulty screen seals were the probable avenue of passage. Fish released in the fyke nets were also captured in the fish return, indicating that fish could move in either direction through the screen seals.

\section{Wapate Screens}

Results from integrity tests at Wapato Screens were simflar to those observed in 1987 (Neitzel et a1. 1987). Test fish passed through the seals on some drum screens, and over some screens as they rotated. Passage over the screens ("rollover") was generally limited to test fish released close to the screen face at the water surface. We observed one wild spring chinook salmon fry passing over screen 15. Rollover also appeared to be related to fish size. Fall chinook salmon (75 $\mathrm{mm} F L$ ) released from YIN net pens did not pass over screens. Although several weak or disoriented fish were impinged briefly on the screen face, their mass prevented them from rolling over the drum screens. Additionally, the new seals installed along the circumference at each end of the drum screens appeared to be tighter than was the case before 1988.

Almost half the test fish recovered in fyke nets behind the screens probably resulted from rollover. Sixty test fish were caught in fyke nets (Table 6): 27 rolled over the screens. Capture of coho salmon smolts indicated that screen seals were poor at screen 15. After screen seals were repalred, few coho salmon smolts were captured behind screen 15 . The lower catch could reflect the improved seals, fewer coho present in front of the screens, or a combination of both. Captures of fall chinook salmon in fyke nets behind screens 13-15 during release of fish from YIN net pens indicated that passage continued to occur at screen 15 despite repairs. The few fish caught behind screens 13 an 14, and some of the fish caught behind screen 15, were severely cut and crushed. Although the number of fish captured in nets was less than $0.1 \%$ of release, their presence confirms the need for meticulous maintenance and care of screen seals.

\section{Sunnyside screens}

Monttoring of screens 8 and 17 during YIN release of fall chinook salmon indicated that seals at screen 17 were faulty. Repairs were made just prior to tests at Sunnyside Screens. Although few smolt-size fish were caught at the Sunnyside Screens after the seal repairs were made, fewer 
fish were present in the screen forebay than during tests at Wapato Screens.

Most test fish captured in fyke nets behind the screens were the result of rollover. However, some fish counted as "rollovers" were injured or were stuck in the seal at the downstream end of the screens. Several fish passed over screen 7 with thetr heads crushed between the seal and screen face. 
SUMMARY

Release and capture and monttorting studles have been conducted at five diversion screen factlittes in the Yakima River Basin: Sunnyside Screens (Neitzel et al. 1985), Richland Screens (Neltzel et a1. 1986, 1987), the Toppenish/Satus Screens (Neltzel et al. 1986). Wapato Screens (Neltzel et a) 1987), and Toppentsh Creek Screens. The objective was to determine if fish diverted into an irrfgation canal are safely diverted back to the river. The objective is met by deternining if: 1) fish that pass through the diverston are kllled, injured, or eaten by predators: 2) fish migration is delayed at the screen structure; or 3) fish are prevented from passing through or over the screens. These possiblitttes are addressed in vartous phases of the work plan (Appendix A).

\section{PHASE I}

Phase I tests were conducted at Sunnystde Screens with chinook salmon and steelhead smolts. Test data indicated that fish safely pass through all components of the bypass system. No Phase I tests were conducted at Richland. Toppenish/Satus, or Toppentsh Creek screens because the fish bypass systems do not incorporate intermedlate and terminal bypasses. traveling screens, or fish water pumpback systems in thetr designs. No Phase I tests were conducted at Wapato Screens because components of the fish passage facility did not signiflcantly differ from components at the Sunnyside Screens. which were proven safe for fish passage.

\section{PHASE LI}

Phase II a tests are complete at five screening facllities. At Sunnyside Screens, fish were released at etther the trash racks or head gates. Fish captured after moving through the screen forebay and diversion system were not injured or kllled. At Richland. Toppenish/Satus, Wapato, and Toppenish Creek screens, fish were released only at the trash racks. Captured fish were not killed or injured. Tests at Sunnyside. Wapato, and Richland Screens were conducted with chinook salmon and steelhead smolts. Tests at Toppenish/Satus and Toppenish Creek Screens were conducted with steelhead smolts.

Phase II tests were conducted at Sunnyside, Richland, Toppentsh Creek, and Wapato screens. At Sunnystde, tests were conducted to evaluate the intermediate bypass system, terminal bypass system, secondary separation chamber, and primary fish return pipe. At Richland. Toppenish Creek and Wapato Screens, the fish return ptpe was evaluated. Fish successfully passed through each component without injury or delay. 


\section{PHASE ILI}

Phase III tests were conducted at Rlchland. Toppentsh Creek, and Wapato screans. Plpe tests were conducted under two bypass flows at the Richland Screens. Fish were not injured or kllled at efther bypass flow. Evaluations at Toppenish Creek and Wapato Screens were conducted durtng low and full canal flows. Although fish were not injured or kflled in elther test, movement rate was slower during low canal flows. Opportunities to conduct tests under different canal flows were 1 imlted because of delays in construction and startup at Sunnyslde, Richland, and Toppenish/Satus screens. Sunnyside and Toppentsh/Satus screens were evaluated only under full canal flows and Richland Screens only under mintmum flows.

\section{PHASE IV}

Native fish were collected during all bypass tests. Gut contents of predacious fish were examined. Predactous bird activity was monttored near each screening factlitiy. Although predation by nattve spectes does not appear to occur at screening facllittes, hatchery-released salmonids sometlmes congregate in the screens forebay, and prey on salmonid fry. The data we have collected cannot be used to infer that predation at the screens is greater than predation in the river.

Rotary drum screens were examined to determine if fish were impinged on or passed over the screens. Successful integrity tests were completed at the Richland, Toppenish Creek. Sunnystde, and Wapato screens. Richland Screens are effective at preventing fish from entering the irrigation canal:

although some fish passed over screens and through faulty screen seals at the Toppentsh Creek. Sunnyside, and Wapato screens, screen efficiency is near 99\%. Screen integrity tests at Toppenish/Satus were unsuccessful because we did not collect any fish. including our control fish. downstream of the screens. 


\section{BECOMMENDALIONS}

Flshertes evaluations have been conducted at five screening factlittes: Sunnyside, Richland. Toppentsh/Satus. Wapato, and Toppenish Creek screens. Data were collected to address five areas of concern: fish survival. predation. migration delays. screen passage, and effects of operating conditions. Test results addressing each concern were integrated to evaluate screens effectiveness.

Although data indlcate that fish are not descaled or kllled as they are diverted by the screening factlities, descaling tests should continue at future diversion sites to assess potential stte-spectfic problems and correlate descale to canal operations (Phase III). Canal operating condtions are of greatest concern during canal startup. and during peak migration of native salmonid stocks in the vicinity of each screening factlity.

We have not observed increased predation on juventle salmonids in or near screen facllittes that could be directly attributed to the screens. However. increased predation on fish that pass through the screening facllities should be quantifled relative to predation in the river. Although native predactous fish populatiois do not appear to concentrate within the screening facilities, hatchery-released salmonids can pose a predation threat if the fish do not migrate from the river following release. The location and operation of irrigation diverstons should be considered in planning future hatchery releases.

Operating criteria should stress that fish bypass flow is important to achieving effective fish bypass. Fish are not involuntartly delayed at or within the screening facllities when bypass flows are set according to operating criteria and properly maintained. The potential for fish delay in screen facilities should be compared to migration rates for tish that remain in the river. At Wapato screens. low bypass flows. whether caused by low forebay elevation or malfunctioning components in the bypass system. may contribute to slower fish movement through the facility. Boulders that blocked the mouth of the fish return pipe at Toppenish creek Screens resulted in reduced bypass flows and were a potential site for fish injury. The fish bypass system should be thoroughly checked and calibrated at each screening facility at the beginning of each irrigation season.

Tests to evaluate screen integrity should have a high priority. Screen integrity tests at Toppenish Creek, Sunnyside, and Wapato indicate that screen seals play a vital role in preventing fish from entering the irrigation canal. Although annual inspection and replacement of screen seals might reduce losses, a new seal design may be necessary if the present loss rate is not acceptable. 
Passage of salmontds over the drum screens is rare. High approach velocittes at some screens may result in a small number of salmonid fry being lost over the screens; however. larger fingerlings and fry cannot pass over the drum screens. Passage over screens appeared related to the presence of drfftwood or other floating matter at the water surface in front of screens with high water flow. Stoplog adjustments behind screens to achleve unfform flow appeared to reduce rollover of test fish at wapato Screens.

Operating criteria for each screening factlity should be revtewed annually to address changes in screens operations. Criterta must correspond with measurement facilities at the screens. Some staff gauges needed to adjust bypass at the Wapato Screens are not installed. Additionally. changes in operations resulting from inoperable components in the bypass system need to be addressed. For example. When the traveling screens are inoperable. there are several options for operating the bypass. Traveling screens can be removed and water and fish will return to the rtver through the wastewater pipe over Gates 5 and 6 . This could result in injurling fish because the waste-water pipe is not designed to transport fish.

With one traveling screen out of service, it could be left in place and twice the flow passed through the operable screen. This increases the probability of impinging fish on the traveling screen. Although flow could be increased through the primary fish return pipe, the capacity of this pipe to safely return fish to the river has not been assessed. Another option may be to reduce flows in the bypass when only one traveling screen is in service. With this option. fish travel time may be affected. For those options that may be used regularly or for long periods of time. potential fishertes tmpacts of the operational and matntenance procedure should be assessed. 


\section{BEFERENCES}

Basham, L. R., M. R. Delarm, J. B. Athern, and S. W. Pettit. 1982. Eish Iransportation Oversight Team Annual Report. FY 1981: Transport Operations on the Snake and Columbia Rivers. Technical Services Division. Nortliwest Regional Office. National Oceanic and Atmospheric Administration. National Marine Fisheries Service. Portland, Oregon.

Bureau of Reclamation. 1984. Finding of Ne Significant Impact: Fish Passage and Protective Facilities. Yakima River Basin. Washington. Bureau of Reclamation. Pacific Northwest Region. Boise, Idaho.

Easterbrooks, J. A. 1984. Juvenile Fish Screen Design Criteria: A Review of the Objectives and Scientific Data Base. State of Washington Department of Fisheries. Habitat Management Division. Yakima. Washington.

Fast. D.. J. Hubble, and B. Watson. 1986. Yakima River Spring Chinook Enhancement Study Fisheries Resources Management. Yakima Indian Nation. Prepared by the Division of Fisheries, Yakima Indian Mation, for the Bonneville Power Administration. Portland, Oregon.

Hollowed. J. J. 1984. 1983 Yakima River Fall Fish Counts at Prosser Dam. Yakima Indian Nation. Fisheries Resource Management Technical Report No. 84-11. Yakima Indian Nation. Toppenish. Washington.

Holman, J. P. 1971. Experimental Methods for Engineers. McGraw-Hill. New York.

Mainland. D., L. Herrera, and M. I. Sutcliffe. 1956. Lables for Use with Binemial Samples. Mainland. Herrera, and Sutcliffe. New York.

Mood. A. M.. F. A. Graybi11, and D. C. Boes. 1974. Introduction te the Theory of Statistics. McGraw-Hill. New York.

Neitzel, D. A., C. S. Abernethy, and E. W. Lusty. 1987. A Fisheries Evaluation of the Richland and Toppenish/Satus Canal Fish Screening Facilities. Spring 1986. Prepared by the Pacific Northwest Laboratory. Richland. Washington, for the Division of Fish and Wildlife, Bonneville Power Administration. Portlarid. Oregon.

Neitze1, D. A., C. S. Abernethy, E. W. Lusty, and L. A. Prohammer. 1985. A Fisheries Evaluation of the Sunnyside Canal. Fish Screening Facility. Soring 2985. Prepared by the Pacific Northwest Laboratory, Richland. Washington. for the Division of Fish and Wild'ife, Bonneville Power Administration. Portland, Oregon.

Neitze1, 0. A., C. S. Abernethy. E. W. Lusty, and S. J. Wampler. 1988. A Fisheries Evaluation of the Richland and Wapato Canal Fish Screening Facility. Spring 1987. Prepared by the Pacific Northwest Laboratory. Richland. Washington. for the Division of Fish and Wildife. Borneville Power Administration. Fortiand, Oregon. 


\section{APPENDIX A}

WORK PLAN

The work plan for all BPA-funded screen evaluations consists of four phases. Phases I through III are mark/release studies to determine changes in fish condition and transit time through screen facilities. Phase IV is a monitoring study to determine presence of predators near the screen facilities, passage through the diversions into the canals, and arrival times for migrating fish populations.

The work plan addresses a generic facility (i.e.. head gates, trash rack. screens, fish-water-pumpback system. separation chamber, and fish return pipe). Although some facility components may be different or not used at a given facility: however, the four-phase concept will be applied as practicable. Additionally, it is not always possible to implement all phases at all sites. The most important data necessary to evaluate a specific screen site are determined by the fisheries management agencies in the Yakima Basin. The decision determines the first phase of the work plan to be implemented at a site.

\section{PHASE I}

Phase I tests are conducted to determine the condition of fish after passage through the fish diversion components of a screen facility. Phase $I$ is accomplished by releasing branded fish at the entry to the fish bypass system. Released fish are collected near the terminus of the fish return pipe. The percent of descaling, number of fish killed (both immediately and after 4 days), and rates and extent of injuries are recorded.

Several collection systems are considered. including a net at the terminus of the primary fish return pipe and a modified inclined plane or net near the terminus of the diversion system. The collection system is chosen after a site-specific evaluation of the screen facility. Collection systems are tested to determine their effectiveness and to assure collected fish are not being injured or stressed by the system. Tests are conducted by releasing fish in and near the collection system. Efficiency and handiing are evaluated throughout the tests.

Collection of fish begins immediately after release. Collection duraiion and interval varies with the site and test objective. Where the primary objective is to estimate the proportion of released fish that are killed or descaled, we fish until we get a $95 \%$ confidence interval estimate that is acceptable. When estimating travel time through a component of the screen facility, we use a similar criterion for developing sample duration. 
Samples are collected continuously, if possible. during the first 24 to 48 $h$ after release. If a higher catch total is required after $48 \mathrm{~h}$. collection is made to the period of highest probable catch for the next $48 \mathrm{~h}$.

A hypothesis as to the fate of noncollected fish for each release is based on catch efficiency data collected during control tests, the duration of sample effort. and data from replicate tests when available.

Expected results from Phase I include: 1) percent of fish killed or descaled during passage through the bypass system on the screen diversion: 2) the change in condition for fish that survive passage through the bypass: 3 ) a hypothesis as to the fate of noncollected fish: 4) potential effects of sampling equipment; and 5) handling effects of the mark. release, and capture techniques.

\section{PHASE II}

Phase II tests are conducted to determine fish condition after passage from upstream of the trash racks through the bypass system (Phase IIa) or after passage through individual fish passage components of the screen facility (Phase IIb). The choice of test depends on whether fish are killed or injured during Phase I. If there are no mortalities or injuries after passage through the bypass system during Phase I. Phase II a follows Phase I. If there are mortalities or injuries during Phase I. Phase Ilb follows phase I.

Phase IIa.

If no effect is observed in Phase I, condition of fish that pass through the screen facility (from upstream of the trash racks through the bypass) is determined. The species tested is the same as used in Phase I, if possible.

Fish are released at the trash rack and collected at the terminus of the fish return pipe. Percent descaling. number killed (immediately and after 4 days). and rates and extent of injuries are noted. Releases are made in and near the collection system to determine collection efficiency and handling effects. The condition of fish that enter the heaciworks of the canal and are subsequently returned to the river through the primary fish return pipe, and transit time from the trash racks to the river discharge are determined. Expected results include: 1) change in condition for fish that pass through the entire fish diversion and are returned to the river. 2) hypothesis as to the fate of noncollected fish: 3) transit time for fish through the facility; and 4) collection efficiency and handing effects. 
Phase IID.

If an effect is observed in Phase I, the condition of fish that pass through individual components of the fish bypass system. including the intermediate bypass pipe, the secondary separation chamber, the traveling screens, and the primary fish return pipe, are determined. Species tested are the same as in Phase 1 , if possible. The number released are determined by the same criterla used in Phase I.

Fish are released in individual components of the bypass system and collected at the terminus of the component or the primary fish return pipe. depending on the data needed and the possibility of sampling within the component. Condition of fish at the discharge and through the bypass and secondary separation chamber, transit time across the facility, and transit time through the secondary separation chamber are determined. Expected results include identification of 1 ) hypothesis as to the fate of noncollected fish: 2) bypass components that adversely affect condition of fish passing through the fish screen facility: and 3 ) possible changes to the screen facility to reduce identified effects.

\section{PHASE III}

Phase II t tests determine screen operating conditions and canal flow changes that may affect screens efficiency. Test design. test organisms, and most study objectives are the same as those in Phases I and IIa. operational conditions that maximize screen efficiency, effectiveness of screens over a range of flows, and factors that affect fish transit time through the facilities are determined. Expected results include: 1) any change in effectiveness of the facility over a range of canal flows, and 2) factors that may change the transit time through the facility.

\section{PHASE IV}

Phase IV monitoring is conducted to determine if piscivorous predators are present near the screen facility and if fish can pass through or over the screen facility into the canal. Phase IV has two parts: Phase IVa examines presence and temporal distribution of predators near the screens. Phase IVb examines rates of impingement on screens.

Phase IVa.

Phase IVa includes use of an inclined plane, fyke nets, beach seines, or electroshocker to monitor presence and temporal aistribution of natural fish populations near the facility. Proposed monitoring locations are downstream of the headworks, in the canal downstream of the facility, and in the river downstream of the discharge. 
The collection equipment are used at predesignated times. Sample duration is determined by consultation with BPA and Yakima Basin fisheries agencies and the priority of the Phase IV work. Phase IVa monitoring at the inclined plane will continue during every mark/release test. The presence and quantity of any predators are noted. Presence of fish populations near the facility and fish passage through the facility are noted. Expected results include: 1) qualitative determination of the fish predator populations near the facllity: 2) effertiveness of screens in keeping fish from entering the canal downstream of the screens: and 3 ) arrival time at the screen facility for salmonid populations.

Phase IVk.

Phase IVb monitoring examines the rotating screens and the vertical traveling screens. If necessary. Phase IVb objectives may be met with studies other than monitoring. For example, marked fish may be released in front of the screens, and subsequent monitoring behind the screens will indicate if fish enter the canal through or over the screens. Rates of impingement on the rotating and traveling screens are determined. Expected results include: 1) impingement rate on rotating screens: 2) the rate of impingement on the traveling screens; and 3) operational conditions that increase impingement. This task is not necessary if impingement does not occur during operation of the facility. The latter is evaluated during Phase I and II. 


\section{APPENDIX B}

RELEASE AND CAPTURE DATA FROM SUNNYSIDE. RICHLAND. TOPPENISH/SATUS. WAPATO. AND TOPPENISH CREEK CANAL EISH SCREENING FACILITIES

This appendix contains data collected from 1985 through 1987 at Sunnyside (Neitzel et al. 1985), Richland (Neitzel et al. 1986, 1987). Toppenish/Satus (Neitzel et a1. 1986), and Wapato Canal (Neitzel et al. 1987 ) Fish Screening Facilities. Data collected 1988 at Toppentsh Creek. Wapato, and Sunnyside Screens are presented. Data are sometimes combined (i.e... individual trials within a test series were combined for a single estimate). Descaled fish were considered dead for the estimates presented. Dead and descaled fish were combined to evaluate screen performance.

Data from Sunnyside Screens (Neitzel et a1. 1985) indicate that fish are safely diverted from the canal to the river (Tables B.1 through B.7). Tables B.1 and B.2 represent evaluation of the inclined plane and fyke net. Both samplers collected fish without killing or descaling. Tables B. 3 and B.4 represent evaluations of test fish condition before release in the canal or screen facility. Test fish were in good condition before release. Tables B.5 and B. 6 show results of screening facility evaluations. Descaling data from upriver hatchery and native fish are shown in Table B.7. Table B.45 shows the estimated times for test fish to move through the Sunnyside Screen Facility. Screen integrity tests indicate that less than $2 \%$ of test fish pass through or over the screens. Screen integrity data are presented in Tables B.46 through B. 48 .

Data from Richland Screens (Neitzel et al. 1986) indicate that fish are safely diverted from the canal to the river. Data from the 1986 evaluation are shown in Tables B.8 through B.15. Data from the 1987 evaluation is shown in Tables $B .25$ and B.29. Tables $B .8$ and B.9 represent the evaluation of inclined plane and fyke nets. The inclined plane collected fish safely. The fyke net descaled too many fish to be used as an effective collection device at the terminus of the Richland Canal return pipe during flows of $0.6 \mathrm{~m}^{3} / \mathrm{sec}$ (20 cfs). Therefore, we used an electroshocker to collect fish and evaluate the fish return pipe. Tables B.10 and B.11 represent evaluations of test fish condition before their release in the canal. Fish were in good condition before release. Tables $B .12$ and $B .13$ show results of screening facility evaluations. Table B.14 gives estimated times for test fish to move through the Richland Screen Facility. Descaling data from upriver hatchery and native fish are shown in Table B.15 (1986 data) and Table B.25 (1987 data). Screen integrity data at Richland Caral in 1987 are shown in Table B.29.

Data from the Toppenish/Satus Screens indicate that fish are safely diverted from the canal to the river. Data are presented in Tables B.16 through B.19. Table B.16 represents evaluations of test fish condition 
before release in the canal. The fish were in marginal condition before testing. Water temperature at the canal during testing was near $20^{\circ} \mathrm{C}$; therefore we acclimated test fish to near $20^{\circ} \mathrm{C}$. Although scales were loose on test fish and many became descaled during acclimation and transport, the test data are useful. The condition of test fish was not degraded by passage through the screen diversion based on comparing test arid control populations. Table B.17 shows results of screening facility evaluations. Table B.18 are the estimated times for test fish to move through the Toppenish/Satus Screen Factility. Descaling data from upriver hatcheryreleased and native fish are presented in Table B.19.

Data from Wapato Screens indicate that fish are safely diverted from the canal to the river. Evaluation of potential screen passage at wapato indicates that few fish pass through and over the screens; estimated numbers based on tests with fall chinook salmon fry are less than $2 \%$. Data from the tests at the Wapato Screens are shown in Tables B.20 through B.24. B.26 through B.28, and B.30 through B.32. Data in Table B.20 represents evaluations of the inclined plane and nets used to capture fish at Wapato screens. The plane and nets safely collected fish. Table B.21 and B.22 represent evaluations of test fish condition before release in the canal. Fish were in good condition before release. Tables B.23 and B.24 show results of screening facility evaluations. Table B.26 presents descaling data on upriver native and hatchery salmontds captured during evaluation tests. Table B.27 shows data from a test of the fish return pipe at Wapato Screens. Table B.28, B.32, and B.41 give data used to estimate migration time through the screen facility for test fish. Tables B.30, B.31, B.42. B.43, and B.44 give the data from screen integrity tests at Wapato screens.

Data from Toppenish Creek Screens indicate that fish are safely diverted from the canal to the river (Tables B.33 through B.40). Table B.33 represents evaluation of the inclined plane. The plane collected fish without killing or descaling. Table B.34 represents evaluations of test fish condition before release in the canal or screen facility. Test fish were in good condition before release. Data for descaling evalutions are shown in Tables B.35 and B.38. Table B.36 shows estimated times for test fish to move through the Toppenish Creek Screen Facility. Tables B. 39 and 40 show results of screen integrtty evaluations. Less than $1 \%$ of test fish pass through or over the screens. 
IABLE B.1. Percentage of Coho Salmon Oncorhynchus kisutch Smolts Descaled or Killed During Tests of the Inclined Plane at Sunnyside Canal Fish Screening Factlity. Spring 1985

\begin{tabular}{|c|c|c|c|c|c|}
\hline \multirow[b]{2}{*}{$\begin{array}{c}\text { TEST } \\
\text { REPLICATE } \\
\end{array}$} & \multicolumn{3}{|c|}{ NUMBER OF FISH } & \multirow{2}{*}{$\begin{array}{c}\text { PERCENT } \\
\text { DESCALED OR } \\
\text { KILLED } \\
\end{array}$} & \multirow{2}{*}{$\begin{array}{c}95 \% \\
\text { CONFIDENCE } \\
\text { INTERVAL } \\
\end{array}$} \\
\hline & $\begin{array}{c}\text { PLACED IN } \\
\text { NET }\end{array}$ & CAPTURED & $\begin{array}{c}\text { DESCALED OR } \\
\text { KI LLED }\end{array}$ & & \\
\hline 1 & 10 & 7 & 0 & 0 & $0-41.0$ \\
\hline 2 & 10 & 9 & 0 & 0 & $0-33.6$ \\
\hline 3 & 10 & 10 & 0 & 0 & 0.30 .8 \\
\hline 4 & 10 & 10 & 0 & 0 & $0-30.8$ \\
\hline 5 & 10 & 10 & 0 & 0 & $0-30.8$ \\
\hline 6 & 10 & 8 & 0 & 0 & 0.37 .0 \\
\hline 7 & 10 & 10 & 0 & 0 & $0-30.8$ \\
\hline 8 & 10 & 10 & 0 & 0 & $0-4.8$ \\
\hline TOTAL & 80 & 74 & 0 & 0 & 0.4 .8 \\
\hline
\end{tabular}

TABLE B.2. Percentage of Steelhead Oncorhynchus mykiss and Chinook Salmon 0. tshawytscha smolts Descaled or Killed During Tests of the Fyke Net at Sunnyside Canal Fish Screening Facility. Spring 1985

\begin{tabular}{|c|c|c|c|c|c|}
\hline \multirow{2}{*}{$\begin{array}{c}\text { SPECIES \& } \\
\text { TEST } \\
\text { REPLICATE }\end{array}$} & \multicolumn{3}{|c|}{ NUMBER OF FISH } & \multirow{2}{*}{$\begin{array}{l}\text { PERCENT } \\
\text { DESCALED OR } \\
\text { KILLED } \\
\end{array}$} & \multirow{2}{*}{$\begin{array}{c}95 \% \\
\text { CONFIDENCE } \\
\text { INTERVAL }\end{array}$} \\
\hline & $\begin{array}{l}\text { PACED ON } \\
\text { PLANE }\end{array}$ & CAPTURED & $\begin{array}{c}\text { DESCALED OR } \\
\text { KILILED }\end{array}$ & & \\
\hline Steelhead 1 & 50 & 8 & 0 & 0 & $0-36.0$ \\
\hline Steethead 2 & 50 & 28 & 0 & 0 & 0.12 .3 \\
\hline steelhead 3 & 55 & 21 & 0 & 0 & $0-16.1$ \\
\hline TOTAL. & 155 & 57 & 0 & 0 & 0.6 .3 \\
\hline $\begin{array}{l}\text { Chinook } \\
\text { Salmon } 1 \\
\end{array}$ & 50 & 21 & 0 & 0 & 0.16 .1 \\
\hline
\end{tabular}


IABLE B.3. Percentage of Steelhead Oncorhynchus mykiss Smolts Descaled Before Being Used in Tests at Sunnyside Canal Ftsh Screenting Factlity, Spring 1985

\begin{tabular}{|c|c|c|c|c|}
\hline $\begin{array}{l}\text { TEST } \\
\text { SITE } \\
\end{array}$ & $\begin{array}{r}\text { NUMBE } \\
\text { EVALUATED }\end{array}$ & $\begin{array}{l}\text { FISH } \\
\text { DESCALED }\end{array}$ & $\begin{array}{l}\text { PERCENT } \\
\text { DESCALED }\end{array}$ & $\begin{array}{c}95 \% \\
\text { CONFIDENCE } \\
\text { INTERVAL }\end{array}$ \\
\hline $\begin{array}{c}\text { Intermedlate } \\
\text { Bypass }\end{array}$ & 24 & 0 & 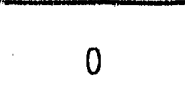 & 0.14 .3 \\
\hline $\begin{array}{c}\text { Terminal } \\
\text { Bypass }\end{array}$ & 13 & 0 & 0 & 0.24 .7 \\
\hline $\begin{array}{l}\text { Trash } \\
\text { Rack }\end{array}$ & 19 & 0 & 0 & 0.17 .7 \\
\hline $\begin{array}{c}\text { Canal Head } \\
\text { Gates }\end{array}$ & 20 & 0 & 0 & $0-16.8$ \\
\hline
\end{tabular}

IABLE B.4. Percentage of Chinook Salmon Oncorhynchus tshawytscha Smolts Descaled Before Being Used in Tests at Sunnyside Canal Fish Screening Facility. Spring 1985

\begin{tabular}{ccccc}
\hline $\begin{array}{c}\text { TEST } \\
\text { SITE }\end{array}$ & NUMBER & OF FISH & $\begin{array}{c}\text { PERCENT } \\
\text { DESCALED }\end{array}$ & $\begin{array}{c}\text { CONFIDENCE } \\
\text { INTERVAL }\end{array}$ \\
\cline { 2 - 5 } $\begin{array}{c}\text { Primary } \\
\text { Return Pish }\end{array}$ & 36 & 0 & 0 & $0-9.7$ \\
$\begin{array}{c}\text { Intermediate } \\
\text { Bypass }\end{array}$ & 20 & 0 & 0 & $0-16.8$ \\
$\begin{array}{c}\text { Terminal } \\
\text { Bypass }\end{array}$ & 20 & 0 & 0 & $0-16.8$ \\
$\begin{array}{c}\text { Trash } \\
\text { Rack }\end{array}$ & 20 & 0 & 0 & $0-16.8$ \\
$\begin{array}{c}\text { Canal Head } \\
\text { Gates }\end{array}$ & 32 & 0 & 0 & 0.9 .7 \\
\hline
\end{tabular}


IABLE B.5. Percentage of Steolhead Oncorhynchus myktss Smolts Descaled or Killed in Each Test at Sunnystde Canal Fish Screentng

Factlity, Spring 1985

\begin{tabular}{|c|c|c|c|c|c|c|}
\hline \multirow[b]{2}{*}{$\begin{array}{c}\text { RELEASE } \\
\text { SITE } \\
\end{array}$} & \multirow[b]{2}{*}{$\begin{array}{c}\text { TEST } \\
\text { REPLICATE } \\
\end{array}$} & \multicolumn{3}{|c|}{ NUMBER OF FISH } & \multirow{2}{*}{$\begin{array}{l}\text { PERCENT } \\
\text { DESCALED } \\
\text { DR KILLED } \\
\end{array}$} & \multirow{2}{*}{$\begin{array}{c}95 \% \\
\text { CONFIDENCE } \\
\text { INTERVAL }\end{array}$} \\
\hline & & RELEASED & CAPTURED & $\begin{array}{l}\text { DESCALED } \\
\text { OR KILLED }\end{array}$ & & \\
\hline $\begin{array}{l}\text { Prtmary Fish } \\
\text { Return Plpe }\end{array}$ & 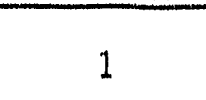 & 50 & -1 & 1 & 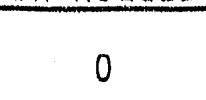 & 0.36 .8 \\
\hline & 2 & 50 & 16 & 0 & 0 & $0-20.6$ \\
\hline & 3 & 72 & 6 & 0 & 0 & $0-45.9$ \\
\hline $\begin{array}{c}\text { Intermed late } \\
\text { Bypass }\end{array}$ & 1 & 275 & 139 & 0 & 0 & $0-2.6$ \\
\hline $\begin{array}{c}\text { Terminal } \\
\text { Bypass }\end{array}$ & 1 & 200 & 112 & 0 & 0 & 0.3 .2 \\
\hline $\begin{array}{l}\text { Trash } \\
\text { Rack }\end{array}$ & 1 & 500 & 126 & 0 & 0 & $0-2.9$ \\
\hline $\begin{array}{c}\text { Canal Head } \\
\text { Gates }\end{array}$ & 1 & 500 & 100 & 0 & 0 & 0.3 .6 \\
\hline
\end{tabular}


IABLEB.6. Percentage of Chinook Salmon Oncorhynchus tshawytscha Smolts Descaled or Killed in Each Test at Sunnyside Canal Flsh Screenting Factlity, Spring 1985

\begin{tabular}{|c|c|c|c|c|c|c|}
\hline \multirow[b]{2}{*}{$\begin{array}{l}\text { RELEASE } \\
\text { SI'TE }\end{array}$} & \multirow[b]{2}{*}{$\begin{array}{c}\text { TEST } \\
\text { REPLICATE }\end{array}$} & \multicolumn{3}{|c|}{ NUMBER OF FISH } & \multirow{2}{*}{$\begin{array}{l}\text { PERCENT } \\
\text { DESCALED } \\
\text { OR KILLED }\end{array}$} & \multirow{2}{*}{$\begin{array}{c}95 \% \\
\text { CONFIDENCE } \\
\text { INTERVAL }\end{array}$} \\
\hline & & RELEASED & CAPTURED & $\begin{array}{l}\text { DESCALED } \\
\text { OR KILLED }\end{array}$ & & \\
\hline \multirow[t]{5}{*}{$\begin{array}{l}\text { Prtmary Fish } \\
\text { Return Plpe }\end{array}$} & 1 & 100 & 83 & 0 & 0 & $0.0-4.4$ \\
\hline & 2 & 100 & 64 & 2 & 3.1 & $0.4-10.8$ \\
\hline & 3 & 100 & 75 & 0 & 0 & $0.0 \cdot 4.8$ \\
\hline & 4 & 100 & 60 & 1 & 1.7 & $0.0-8.9$ \\
\hline & 5 & 100 & 89 & 0 & 0 & $0.0-4.1$ \\
\hline \multirow[t]{5}{*}{$\begin{array}{c}\text { Intermediate } \\
\text { Bypass }\end{array}$} & 1 & 100 & 82 & 2 & 2.4 & $0.3 \cdot 8.5$ \\
\hline & 2 & 100 & 95 & 0 & 0 & $0.0-3.8$ \\
\hline & 3 & 100 & 99 & 0 & 0 & $0.0 \cdot 3.7$ \\
\hline & 4 & 100 & 95 & 2 & 2.1 & $0.3-7.4$ \\
\hline & 5 & 100 & 97 & 0 & 0 & $0.0-3.7$ \\
\hline \multirow[t]{5}{*}{$\begin{array}{l}\text { Terminal } \\
\text { Bypass }\end{array}$} & 1 & 100 & 98 & 2 & 2 & 0.3 .7 .2 \\
\hline & 2 & 100 & 96 & 1 & 1 & $0.0-5.7$ \\
\hline & 3 & 100 & 98 & 0 & 0 & $0.0-3.7$ \\
\hline & 4 & 100 & 98 & 3 & 3.1 & $0.6 \cdot 8.7$ \\
\hline & 5 & 92 & 86 & 1 & 1.2 & $0.0-6.3$ \\
\hline $\begin{array}{l}\text { Trash } \\
\text { Rack }\end{array}$ & 1 & 1000 & 856 & 20 & 2.3 & $1.4-3.6$ \\
\hline \multirow[t]{2}{*}{$\begin{array}{c}\text { Canal Head } \\
\text { Gates }\end{array}$} & 1 & 1000 & 729 & 6 & 0.8 & $0.2-1.6$ \\
\hline & 2 & 1000 & 725 & 21 & 2.9 & $2.0-4.7$ \\
\hline
\end{tabular}


IABLEB.Z. Scale Loss for Hatchery-Released and Nattve Fish Captured During Tests at Sunnyside Canal Fish Screentng Facllity. Spring 1985

\begin{tabular}{ccccc} 
& \multicolumn{2}{c}{ NUMBER OF FISH } & PERCENT & 95\% \\
\cline { 2 - 5 } SPECIES & CAPTURED & DESCALED & DESCALED & CONFIDENCE \\
OR KILLED & OR KILLED & INTERVAL \\
\hline Chinook & 214 & 9 & 4.2 & 2.0 .7 .7 \\
Salmon & 36 & 1 & 2.8 & $0.2-14.7$ \\
Steelhead & 36 & &
\end{tabular}

IABLE B.8. Percentage of Chinook Salmon Oncorhynchus tshawytscha Smolts Descaled or Ktlled During Tests of the Inclined Plane at Richland Canal Fish Screening Factlity. Spring 1986

\begin{tabular}{|c|c|c|c|c|c|c|}
\hline \multirow[b]{2}{*}{ SPECIES } & \multirow[b]{2}{*}{$\begin{array}{c}\text { TEST } \\
\text { REPLICATE }\end{array}$} & \multicolumn{3}{|c|}{ NUMBER OF FISH } & \multirow{2}{*}{$\begin{array}{l}\text { PERCENT } \\
\text { DESCALED } \\
\text { OR KILLED }\end{array}$} & \multirow{2}{*}{$\begin{array}{c}95 \% \\
\text { CONFIDENCE } \\
\text { INTERVAL }\end{array}$} \\
\hline & & RELEASED & CAPTURED & $\begin{array}{l}\text { DESCALED } \\
\text { OR KILLED } \\
\end{array}$ & & \\
\hline \multirow[t]{2}{*}{ Spring } & 1 & 25 & 21 & 0 & 0 & $0-16.1$ \\
\hline & Control & & 19 & 0 & 0 & $0-17.7$ \\
\hline \multirow[t]{3}{*}{$\mathrm{Fall}$} & 1 & 25 & 16 & 0 & 0 & 0.20 .6 \\
\hline & Control & & 20 & 0 & 0 & 0.16 .8 \\
\hline & 2 & 500 & 156 & 0 & 0 & 0.2 .3 \\
\hline
\end{tabular}

IABLE B.9. Percentage of Chinook Salmon Oncorhynchus tshawytscha Smolts Descaled or Kllled During Tests of the Fyke Net at Richland Canal Fish Screening Factlity, Spring 1986

\begin{tabular}{|c|c|c|c|c|c|}
\hline \multirow[b]{2}{*}{ REPLICATE } & \multicolumn{3}{|c|}{ NUMBER OF FISH } & \multirow{2}{*}{$\begin{array}{l}\text { PERCENT } \\
\text { DESCALED } \\
\text { OR KILLED }\end{array}$} & \multirow{2}{*}{$\begin{array}{c}95 \% \\
\text { CONFIDENCE } \\
\text { INTERVAL }\end{array}$} \\
\hline & RELEASED & CAPTURED & $\begin{array}{l}\text { DESCALED } \\
\text { OR KILLED }\end{array}$ & & \\
\hline $1-L(a)$ & 50 & 26 & 0 & 0 & $0.0-13.2$ \\
\hline L-control & 50 & 50 & 0 & 0 & $0.0-7.1$ \\
\hline $1-H(b)$ & 90 & 75 & 14 & 18.7 & $10.6 \cdot 29.3$ \\
\hline$H$-control & 50 & 42 & 17 & 40.5 & $25.6-56.7$ \\
\hline $\begin{array}{l}\text { The L } \\
\text { the fit }\end{array}$ & $\begin{array}{l}\text { signation } \\
\text { return pi }\end{array}$ & $\begin{array}{l}\text { indicates te } \\
\text { ipe. }\end{array}$ & at a flow & rate of 0.6 & $\mathrm{~m}^{3} / \mathrm{sec}$ through \\
\hline $\begin{array}{l}\text { The } H \\
\text { the } f i\end{array}$ & $\begin{array}{l}\text { signation } \\
\text { return pl }\end{array}$ & $\begin{array}{l}\text { Indicates te } \\
\text { ipe. }\end{array}$ & at a flow & rate of 1.6 & $\mathrm{~m}^{3} / \mathrm{sec}$ through \\
\hline
\end{tabular}


IABLE B.10. Percentage of Steelhead Oncorhynchus mykyss Smolts Descaled Before Being Used in Tests at Richland Canal Fish Screening Factlity, Spring 1986

\begin{tabular}{|c|c|c|c|c|c|}
\hline \multirow[b]{2}{*}{ REPLICATE } & \multicolumn{3}{|c|}{ NUMBER OF FISH } & \multirow{2}{*}{$\begin{array}{l}\text { PERCENT } \\
\text { DESCALED } \\
\text { OR KILLED }\end{array}$} & \multirow{2}{*}{$\begin{array}{c}95 \% \\
\text { CONFIDENCE } \\
\text { INTERVAL }\end{array}$} \\
\hline & RELEASED & CAPTURED & $\begin{array}{l}\text { DESCALED } \\
\text { OR KILLED }\end{array}$ & & \\
\hline 1 & 100 & 100 & 0 & 0 & 0.3 .6 \\
\hline 2 & 100 & 100 & 0 & 0 & 0.3 .6 \\
\hline 3 & 101 & 101 & 1 & 1 & 0.5 .4 \\
\hline TOTAL & 301 & 301 & 1 & 0.3 & 0.1 .8 \\
\hline
\end{tabular}

IABLE B.11. Percentage of Chinook Salmon Oncorhyrichus tshawytscha Smolts Descaled Before Being Used in Tests at Richland Canal Fish Screening Factlity, Spring 1986

\begin{tabular}{|c|c|c|c|c|c|}
\hline \multirow[b]{2}{*}{ REPLICATE } & \multicolumn{3}{|c|}{ NUMBER OF FISH } & \multirow{2}{*}{$\begin{array}{c}\text { PERCENT } \\
\text { DESCALED } \\
\text { OR KILLED }\end{array}$} & \multirow{2}{*}{$\begin{array}{c}95 \% \\
\text { CONFIDENCE } \\
\text { INTERVAL }\end{array}$} \\
\hline & RELEASED & CAPTURED & $\begin{array}{l}\text { DESCALED } \\
\text { OR KILLED }\end{array}$ & & \\
\hline 1 & 100 & 100 & 0 & 0 & 0.3 .6 \\
\hline 2 & 100 & 100 & 0 & 0 & 0.3 .6 \\
\hline 3 & 102 & 102 & 0 & 0 & $0-3.6$ \\
\hline TOTAL & 302 & 302 & 0 & 0 & $0-1.2$ \\
\hline
\end{tabular}

IABLE B.12. Descaling and Mortality Data from Release and Capture Tests with Steelhead Oncorhynchus mykiss Smolts at Richland Canal Fish Screenting Faciltty. Spring 1986

\begin{tabular}{cccccc}
\hline & \multicolumn{3}{c}{ NUMBER OF FISH } & PERCENT & $95 \%$ \\
\cline { 2 - 6 } REPLICATE & RELEASED & CAPTURED & DESCALED & OR KILSCALED & CONFIDENCE \\
\hline 1 & 200 & 129 & 1 & 0.8 & $0.2-4.2$ \\
2 & 200 & 132 & 2 & 1.5 & $0.2-5.4$ \\
3 & 200 & 102 & 1 & 1.1 & $0.3-2.8$ \\
\cline { 2 - 7 } & 600 & 363 & 4 & 1.1 & $0.3-2.8$ \\
\hline
\end{tabular}




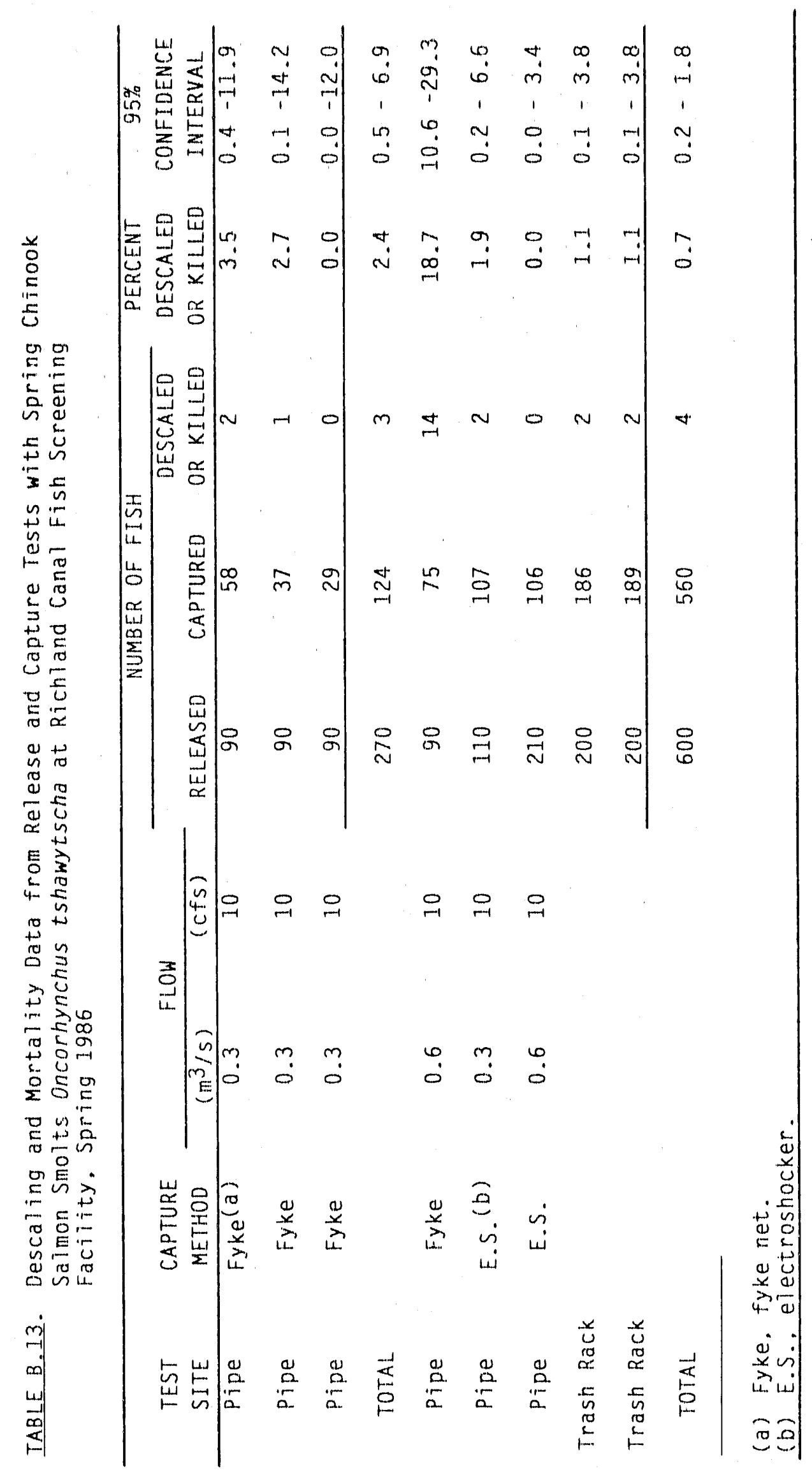

B. 9 
IABLE B.14. Estimated Time (h) to Catch $50 \%$ and $95 \%$ of Test Fish Captured at Richland Canal Fish Screening Facility, Spring 1986

\begin{tabular}{|c|c|c|c|c|c|c|}
\hline \multirow[b]{2}{*}{ SPECIES } & \multicolumn{3}{|c|}{ TIME TO CATCH $(h)$} & \multicolumn{2}{|c|}{ NUMBER OF FISH } & \multirow{2}{*}{$\begin{array}{l}\text { PERCENT } \\
\text { CAPTURED }\end{array}$} \\
\hline & GROUP & $50 \%$ & $90 \%$ & RELEASED & CAPTURED & \\
\hline Steelhead & 1 & 18.0 & 52.5 & 200 & 129 & 64.5 \\
\hline Steelhead & 2 & 21.0 & 48.0 & 200 & 134 & 67.0 \\
\hline Steelhead & 3 & 29.0 & 54.5 & 200 & 102 & 51.0 \\
\hline $\begin{array}{l}\text { Spring } \\
\text { Chinook }\end{array}$ & 1 & 0.5 & 6.5 & 200 & 186 & 93.0 \\
\hline $\begin{array}{l}\text { Spring } \\
\text { Chinook }\end{array}$ & 2 & 1.0 & 5.0 & 200 & 188 & 94.0 \\
\hline $\begin{array}{c}\text { Spring } \\
\text { Chinook }\end{array}$ & 3 & 1.0 & 3.5 & 200 & 185 & 92.5 \\
\hline $\begin{array}{c}\text { Fall } \\
\text { Chinook }\end{array}$ & 1 & 9.5 & 34.5 & 1000 & 638 & 63.8 \\
\hline $\begin{array}{c}\text { Fall } \\
\text { Chinook }\end{array}$ & 2 & 8.5 & 32.0 & 1150 & 682 & 59.3 \\
\hline $\begin{array}{c}\text { Fall } \\
\text { Chinook }\end{array}$ & 3 & 7.0 & 31.0 & 1150 & 809 & 70.3 \\
\hline
\end{tabular}

TABLE B.15. Scale Loss for Hatchery-Released and Native Fish Captured During Tests at Richland Canal Fish Screening Facility. Spring 1986

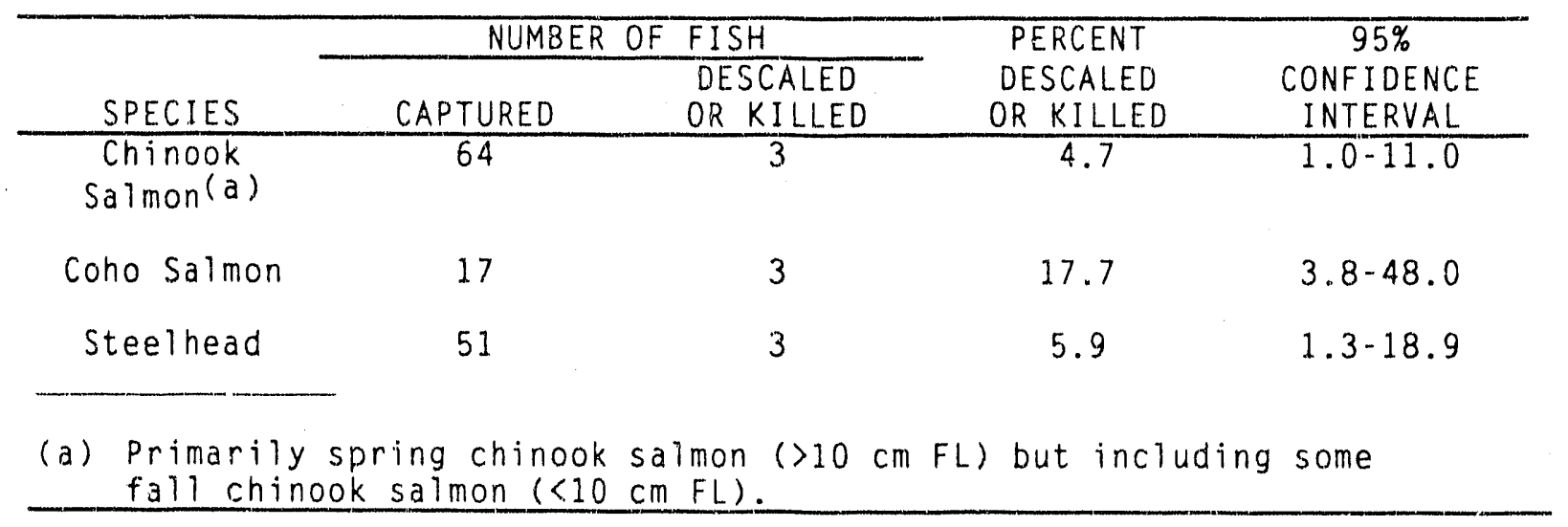


IABLE B.16. Percentage of Steelhead Oncorhynchus mykiss Smolts Descaled Before Being Used in Tests at Toppenish/Satus Canal Fish Screening Facility. Sprirg 1986

\begin{tabular}{|c|c|c|c|c|c|}
\hline \multirow[b]{2}{*}{ REPLICATE } & \multicolumn{3}{|c|}{ NUMBER OF FISH } & \multirow{2}{*}{$\begin{array}{l}\text { PERCENT } \\
\text { DESCALED } \\
\text { OR KILLED }\end{array}$} & \multirow{2}{*}{$\begin{array}{c}95 \% \\
\text { CONFIDENCE } \\
\text { INTERVAL }\end{array}$} \\
\hline & RELEASED & CAPTURED & $\begin{array}{l}\text { DESCALED } \\
\text { OR KILLED }\end{array}$ & & \\
\hline 1 & 103 & 103 & 37 & 35.9 & $26.7-46.0$ \\
\hline 2 & 103 & 103 & 29 & 28.2 & $19.7-37.9$ \\
\hline 3 & 105 & 105 & 16 & 15.2 & $22.0-32.9$ \\
\hline TOTAL & 311 & 311 & 82 & 26.4 & $22.0-32.9$ \\
\hline
\end{tabular}

IABLE B.17. Descaling and Mortality Data from Release and Capture Tests with Steelhead Oncorhynchus mykiss Smolts at Toppenish/ Satus Canal Fish Screening Facility, Spring 1986

\begin{tabular}{|c|c|c|c|c|c|}
\hline \multirow[b]{2}{*}{ REPLICATE } & \multicolumn{3}{|c|}{ NUMBER OF FISH } & \multirow{2}{*}{$\begin{array}{l}\text { PERCENT } \\
\text { DESCALED } \\
\text { OR KILLED }\end{array}$} & \multirow{2}{*}{$\begin{array}{c}95 \% \\
\text { CONFIDENCE } \\
\text { INTERVAL }\end{array}$} \\
\hline & RELEASED & CAPTURED & $\begin{array}{l}\text { DESCALED } \\
\text { OR KILLED } \\
\end{array}$ & & \\
\hline 1 & 520 & 462 & 120 & 26.0 & $23.1-31.3$ \\
\hline 2 & 520 & 463 & 102 & 22.0 & $19.4-27.1$ \\
\hline 3 & 520 & 463 & 40 & 8.6 & $6.2-11.6$ \\
\hline TOTAL & 1560 & 1388 & 262 & 18.9 & $17.4-21.6$ \\
\hline
\end{tabular}


IABLE B.18. Estimated Time (h) to Catch $50 \%$ and $95 \%$ of Test Fish Captured at. Toppenish/Satus Canal Fish Screening Facility, Spring 1986

\begin{tabular}{|c|c|c|c|c|c|c|}
\hline \multirow[b]{2}{*}{ SPECIES } & \multicolumn{3}{|c|}{ TIME TO CATCH $(h)$} & \multicolumn{2}{|c|}{ NUMBER OF FISH } & \multirow{2}{*}{$\begin{array}{l}\text { PERCENT } \\
\text { CAPTURED }\end{array}$} \\
\hline & GROUP & $50 \%$ & $95 \%$ & RELEASED & CAPTURED & \\
\hline Steelhead & 1 & 12.5 & 41 & 520 & 462 & 88.8 \\
\hline Steelhead & 2 & 12 & 46.5 & 520 & 464 & 89.2 \\
\hline Steelhead & 3 & 10 & 42.5 & 520 & 463 & 89.0 \\
\hline $\begin{array}{l}\text { Spring } \\
\text { Chinook }\end{array}$ & 1 & 0.5 & 1.5 & 360 & 356 & 98.9 \\
\hline $\begin{array}{l}\text { Spring } \\
\text { Chinook }\end{array}$ & 2 & 0.5 & 1.5 & 335 & 329 & 98.2 \\
\hline $\begin{array}{l}\text { Spring } \\
\text { Chinook }\end{array}$ & 3 & 0.5 & 1.5 & 335 & 314 & 93.7 \\
\hline $\begin{array}{c}\text { Fall } \\
\text { Chinook }\end{array}$ & 1 & 0.5 & 0.5 & 1000 & 728 & 72.8 \\
\hline $\begin{array}{c}\text { Fall } \\
\text { Chinook }\end{array}$ & 2 & 0.5 & 0.5 & 1000 & 702 & 70.2 \\
\hline $\begin{array}{c}\text { Fall } \\
\text { Chinock }\end{array}$ & 3 & 0.5 & 0.5 & 460 & 330 & 71.7 \\
\hline
\end{tabular}

IABLE B.19. Scale Loss for Hatchery-Released and Native Fish Captured During Tests at Toppenish/Satus Canal Fish Screening Facility. Spring 1986

\begin{tabular}{|c|c|c|c|c|}
\hline \multirow[b]{2}{*}{ SPECIES } & \multicolumn{2}{|c|}{ NUMBER OF FISH } & \multirow{2}{*}{$\begin{array}{l}\text { PERCENT } \\
\text { DESCALED } \\
\text { OR KILLED }\end{array}$} & \multirow{2}{*}{$\begin{array}{c}95 \% \\
\text { CONFIDENCE } \\
\text { INTERVAL } \\
\end{array}$} \\
\hline & CAPTURED & $\begin{array}{l}\text { DESCALED } \\
\text { OR KILLED }\end{array}$ & & \\
\hline Steelhead (1-age) & 20 & 0 & 0 & $0.0-16.8$ \\
\hline Steelhead (0-age) & 69 & 0 & 0 & $0.0-05.2$ \\
\hline Coho Salmon (1-age) & 29 & 0 & 0 & $0.0-12.0$ \\
\hline Chinook Salmon & 25 & 1 & 4 & $0.1-20.4$ \\
\hline
\end{tabular}


IABLE B.20. Percentage of Spring Chinook Salmon Oncorhynchus tshawytscha and Steelhead 0 . mykiss Smolts Descaled or Killed During Tests of the Inclined Plane at Wapato Canal Fish Screening Facility, Spring 1.987

\begin{tabular}{|c|c|c|c|c|c|}
\hline SPECIES & $\frac{\text { NUMBER }}{\text { RELEASED }}$ & $\frac{F \text { FISH }}{\text { CAPTURED }}$ & DESCALED & $\begin{array}{l}\text { PERCENT } \\
\text { DESCALED }\end{array}$ & $\begin{array}{c}95 \% \\
\text { CONFIDENCE } \\
\text { INTERYAL }\end{array}$ \\
\hline Steelhead & 10 & 9 & 0 & 0 & 0.33 .6 \\
\hline Steelhead & 10 & 9 & 0 & 0 & $0-33.6$ \\
\hline TOTAL & 20 & 18 & 0 & 0 & $0-17.7$ \\
\hline $\begin{array}{l}\text { Spring } \\
\text { Chinook }\end{array}$ & 10 & 10 & 0 & 0 & $0-30.8$ \\
\hline $\begin{array}{l}\text { Spring } \\
\text { Chinook }\end{array}$ & 10 & 10 & 0 & 0 & 0.30 .8 \\
\hline TOTAL & 20 & 20 & 0 & 0 & $0-16.8$ \\
\hline
\end{tabular}

IABLE B.21. Percentage of Steelhead Oncorhynchus mykiss Smolts That Were Descaled Before Being Used in Tests at Wapato Canal Fish Screening Facility. Spring 1987

\begin{tabular}{|c|c|c|c|c|c|}
\hline REPLICATE & $\begin{array}{l}\text { CANAL } \\
\text { FLOW } \\
\text { (CFS) }\end{array}$ & $\frac{\text { NUMBEF }}{\text { EXAMINED }}$ & $\frac{F \text { FISH }}{\text { DESCALED }}$ & $\begin{array}{l}\text { PERCENT } \\
\text { DESCALED }\end{array}$ & $\begin{array}{c}95 \% \\
\text { CONFIDENCE } \\
\text { INTERVAL }\end{array}$ \\
\hline 1 & 800 & 65 & 0 & 0 & 0.5 .52 \\
\hline 2 & 800 & 67 & 1 & 1.5 & $0.04-8.04$ \\
\hline 3 & 800 & 68 & 0 & 0 & 0.5 .28 \\
\hline TOTAL & & 200 & 1 & 0.5 & $0.01-2.76$ \\
\hline 1 & 2000 & 35 & 0 & 0 & $0-10.00$ \\
\hline 2 & 2000 & 32 & 0 & 0 & 0.10 .89 \\
\hline 3 & 2000 & 33 & 0 & 0 & 0.10 .58 \\
\hline TOTAL & & 100 & 0 & 0 & $0-3.62$ \\
\hline 1 & 2000 & 38 & 0 & 0 & 0.9 .25 \\
\hline 2 & 2000 & 36 & 0 & 0 & $0-9.74$ \\
\hline 3 & 2000 & 26 & 0 & 0 & 0.13 .23 \\
\hline TOTAL & & 100 & 0 & 0 & $0-3.62$ \\
\hline TOTAL & & 400 & 1 & 0.25 & $0.01 \cdot 1.39$ \\
\hline
\end{tabular}


IABLE B.22. Percentage of Spring Chinook Salmon Oncorhynchus tshawytscha Smolts That Were Descaled Before Being Used in Tests at Wapato Canal Fish Screening Facilities, Spring 1987

\begin{tabular}{|c|c|c|c|c|c|}
\hline \multirow[b]{2}{*}{ REPLICATE } & \multirow{2}{*}{$\begin{array}{l}\text { CANAL } \\
\text { FLOW } \\
\text { (CFS) }\end{array}$} & \multicolumn{2}{|c|}{ NUMBER OF FISH } & \multirow{2}{*}{$\begin{array}{l}\text { PERCENT } \\
\text { DESCALED }\end{array}$} & \multirow{2}{*}{$\begin{array}{c}95 \% \\
\text { CONFIDENCE } \\
\text { INTERVAL }\end{array}$} \\
\hline & & $\frac{\text { EXAMINED }}{74}$ & $\frac{\text { DESCALED }}{0}$ & & \\
\hline 2 & 800 & 59 & 0 & 0 & $0-6.06$ \\
\hline 3 & 800 & 67 & 0 & 0 & $0-5.36$ \\
\hline TOTAL & & 200 & 0 & 0 & 0.1 .83 \\
\hline 1 & 2000 & 35 & 0 & 0 & $0-10.00$ \\
\hline 2 & 2000 & 35 & 0 & 0 & 0.10 .00 \\
\hline 3 & 2000 & 30 & 0 & 0 & $0-11.57$ \\
\hline TOTAL & & 100 & 0 & 0 & $0-3.62$ \\
\hline 1 & 2000 & 33 & 0 & 0 & $0-10.58$ \\
\hline 2 & 2000 & 28 & 0 & 0 & $0-12.34$ \\
\hline 3 & 2000 & 39 & 0 & 0 & 0.9 .03 \\
\hline TOTAL & & 100 & 0 & 0 & $0-3.62$ \\
\hline TOTAL & & 400 & 0 & 0 & $0-0.92$ \\
\hline
\end{tabular}




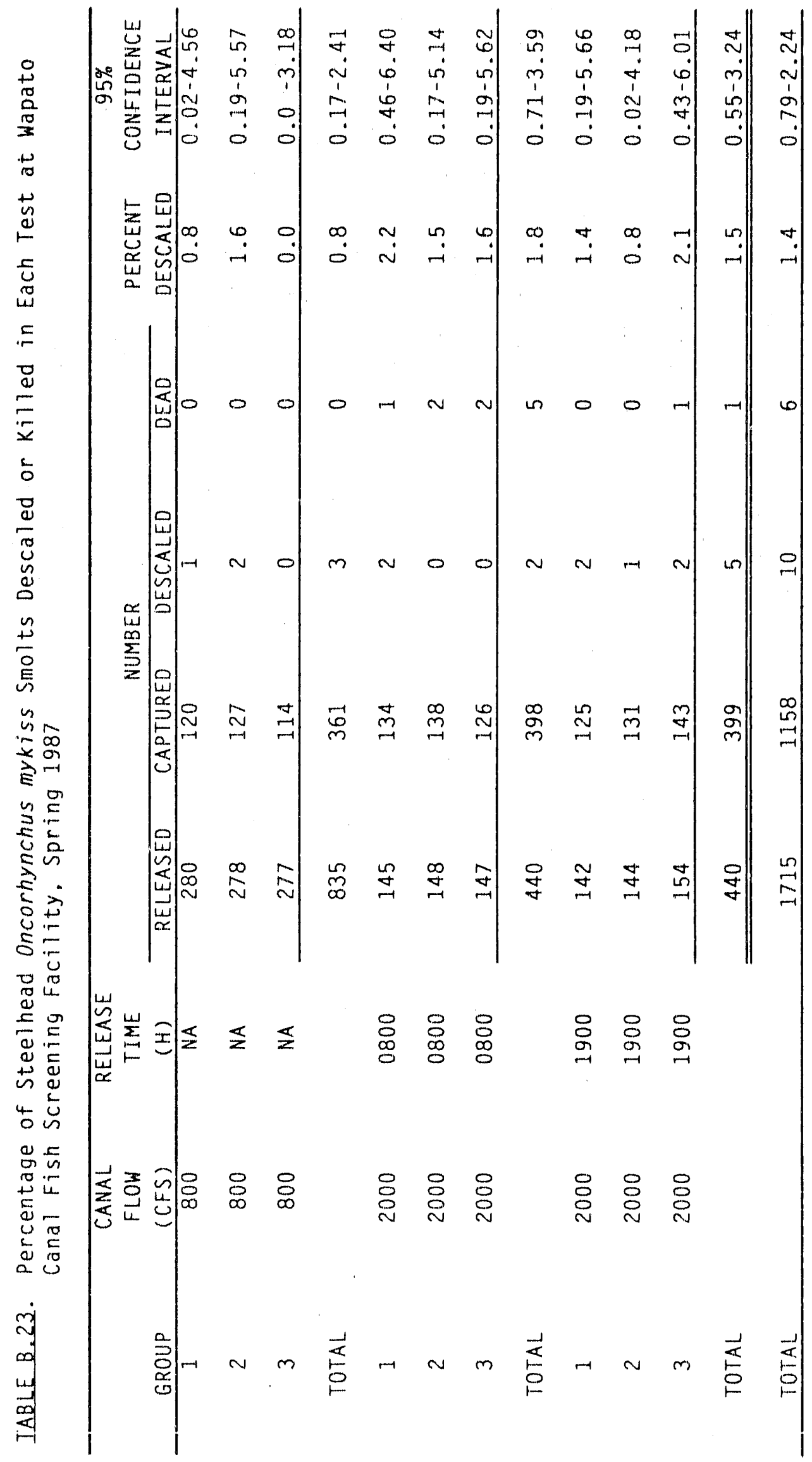




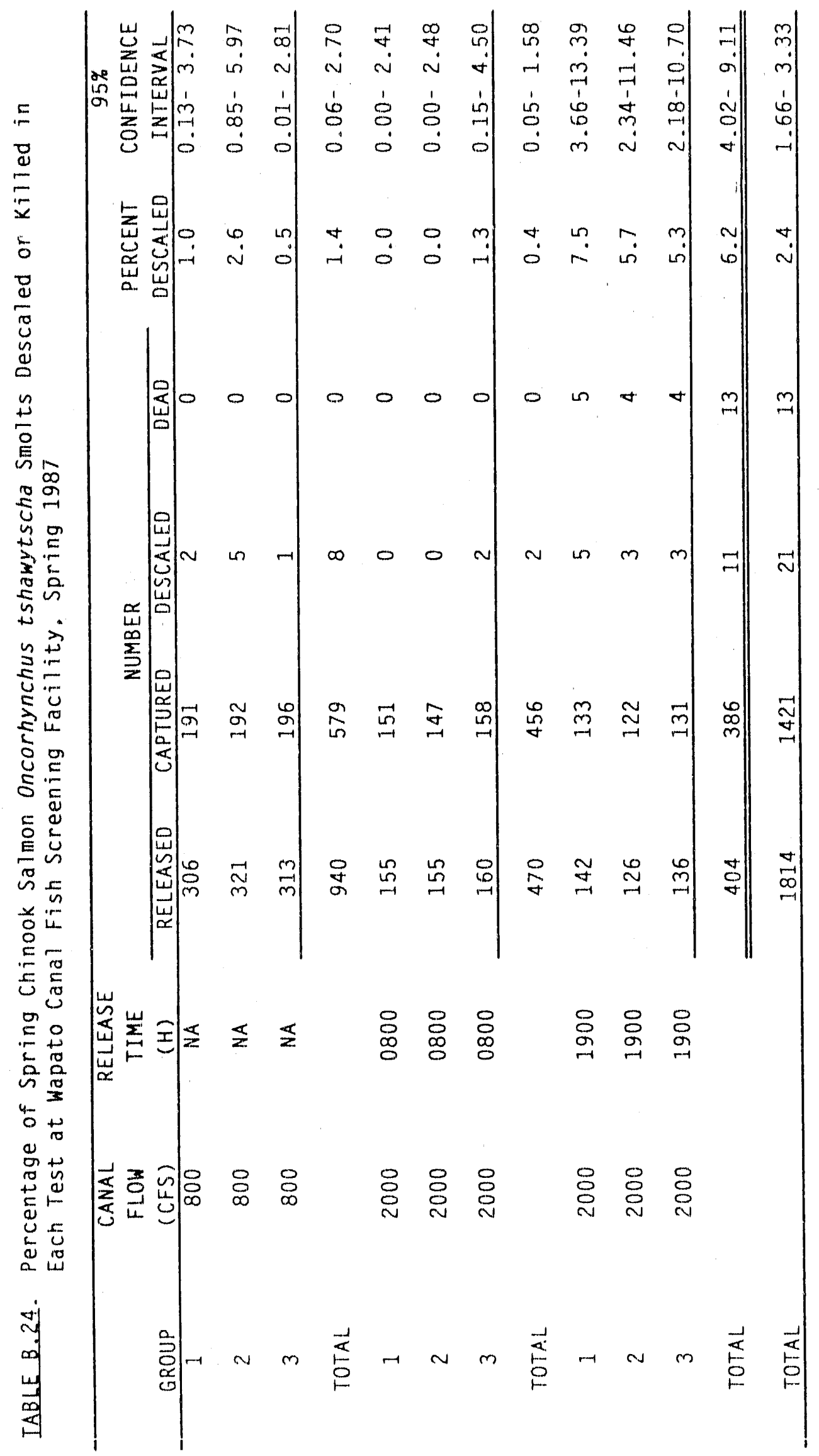


IABLE B.25. Scale Loss for Hatchery-Released and Native Salmonids During Tests at Richland Canal Fish Screening Factlity. Spring 1987

\begin{tabular}{ccccc}
\hline & \multicolumn{2}{c}{ NUMBER } & PERCENT & $\begin{array}{c}95 \% \\
\text { CONFIDENCE } \\
\text { SPECIES }\end{array}$ \\
\cline { 2 - 5 } Steelhead & CAUGHT & DESCALED & DESCALED & $0-28.49$ \\
Spring Chinook & 28 & 0 & 0.0 & $0-12.34$ \\
Fall Chinook & 44 & 0 & 0.0 & $\ldots$ (a) \\
\hline & & $\ldots$ (a) & $\ldots$ (a) & \\
(a) Not evaluated for descaling. & & & \\
\hline
\end{tabular}




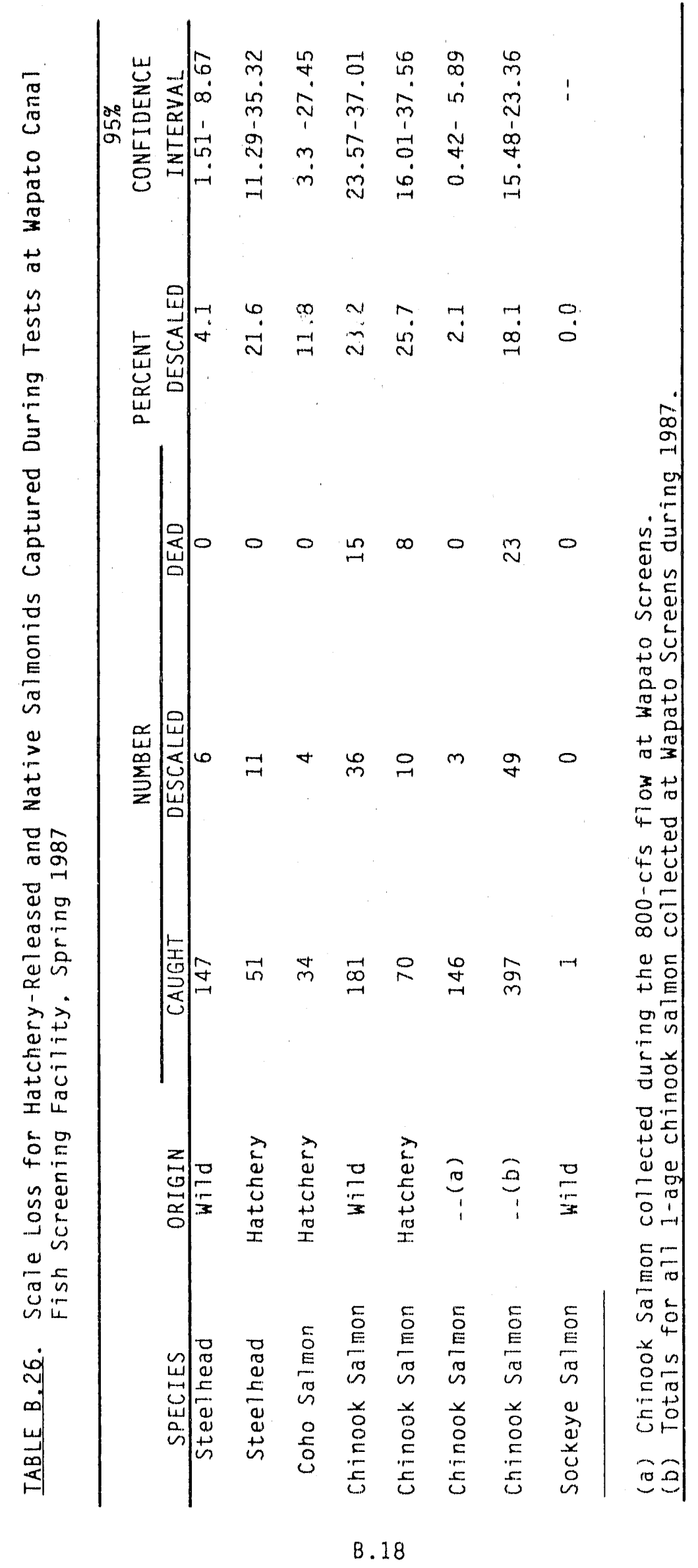


IABLE B.27. Percentage of Test Ftsh Descaled or Ktlled Durting Plpe Tests at Wapato Canal Flsh Screening Factlity. Spring 1987

\begin{tabular}{|c|c|c|c|c|c|}
\hline & \multicolumn{3}{|c|}{ NUMBER } & PERCENT & $\begin{array}{c}95 \% \\
\text { CONFIDENCE }\end{array}$ \\
\hline$\frac{\text { SPECIES }}{\text { Spring Chinook }}$ & $\frac{\text { RELEASED }}{150}$ & $\frac{\text { CAPTURED }}{135}$ & $\frac{\text { DESCALED }}{8}$ & $\frac{\text { DESCALED }}{5.9}$ & $\frac{\text { INTERVAL }}{2.59-11.34}$ \\
\hline Steelhead & 100 & 65 & 1 & 1.5 & $0.00-5.52$ \\
\hline
\end{tabular}




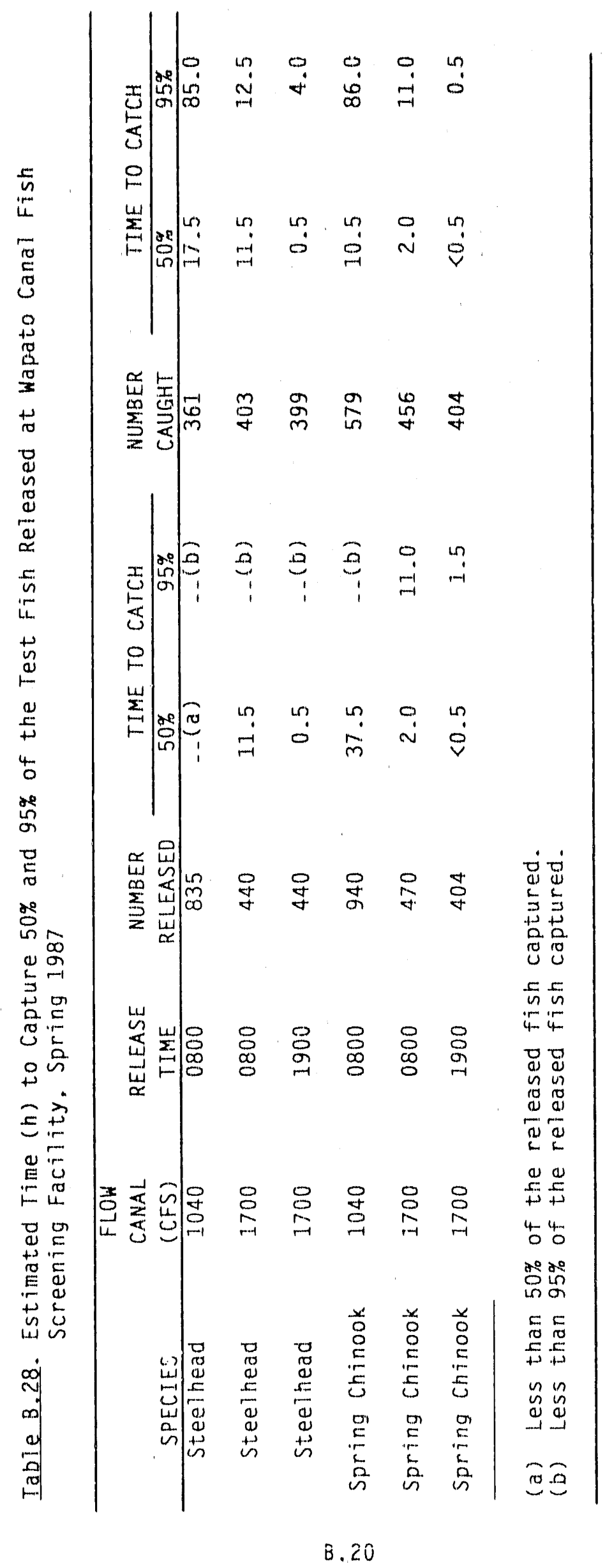




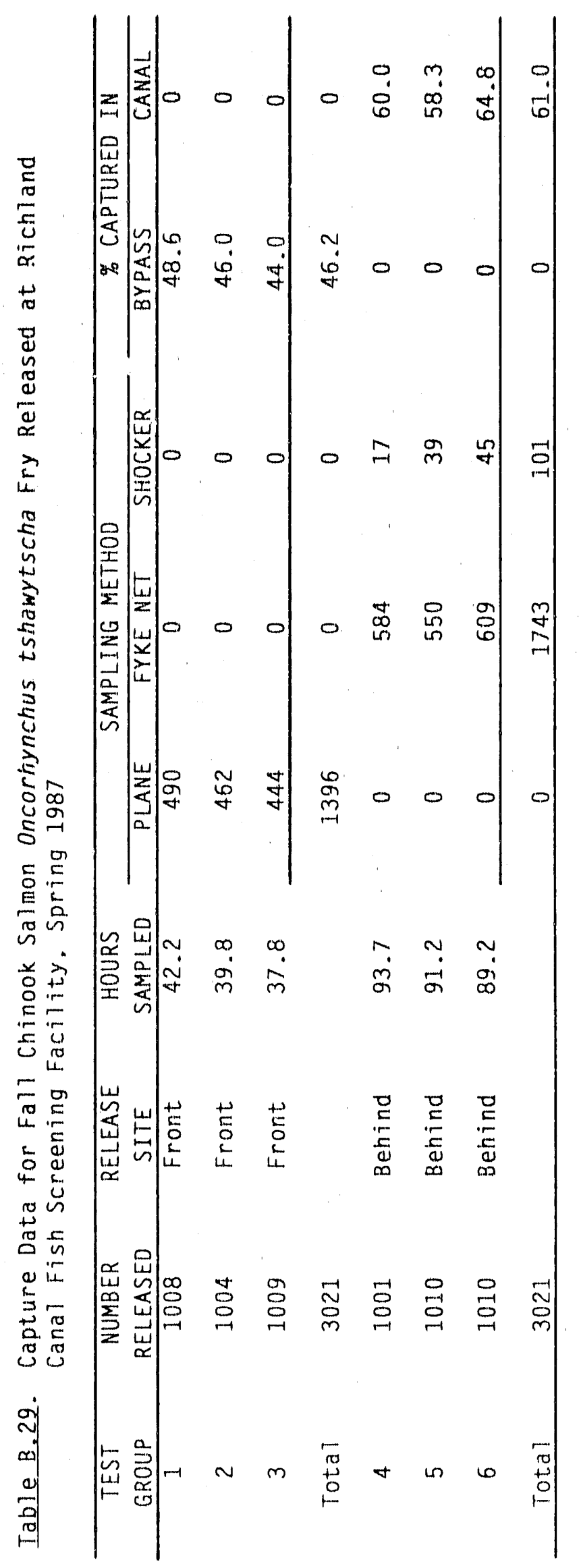


IABLE B.30. Capture Effictencles of the Inclined Plane and Nets and Retention Effictency of the Fyke Nets Used in Screen Integrtty Tests at Wapato Canal Fish Screenting Factilty. Spring 1987

\begin{tabular}{|c|c|c|c|c|c|}
\hline $\begin{array}{l}\operatorname{SCREEN}(a) \\
\text { SECTION }\end{array}$ & $\begin{array}{l}\text { CAPTURE PF } \\
\text { INCLINED PLANE }\end{array}$ & $\frac{\text { BAB I LITY ES }}{\text { NET CAPTURE }}$ & $\frac{\text { IMATE FOR }}{\text { NET RETENTION }}$ & $\begin{array}{l}\text { SCREEN } \\
\text { EFFICIENCY }\end{array}$ & $\begin{array}{c}95 \% \\
\text { CONFIDENCE } \\
\text { INTERVAL }\end{array}$ \\
\hline$\frac{5}{1-5}$ & $\frac{0.94}{0.94 E}$ & $\frac{N E 1 \text { CAP IURE }}{0.33}$ & $\frac{N E I \text { REIENI IUN }}{0.55}$ & 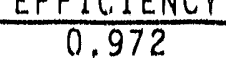 & $0.96-0.99$ \\
\hline $6-10$ & 0.98 & 0.45 & 0.72 & 0.996 & $0.99-1.00$ \\
\hline $11-15$ & 0.95 & 0.93 & 0.97 & 0.950 & $0.94-0.96$ \\
\hline $1 .-15$ & 0.95 & 0.57 & 0.73 & 0.962 & $0.96-0.97$ \\
\hline
\end{tabular}

(a) Screens are numbered from the upstream (NUMBER 1) to downstream screen nearest the separation chamher (NUMBER 15). 


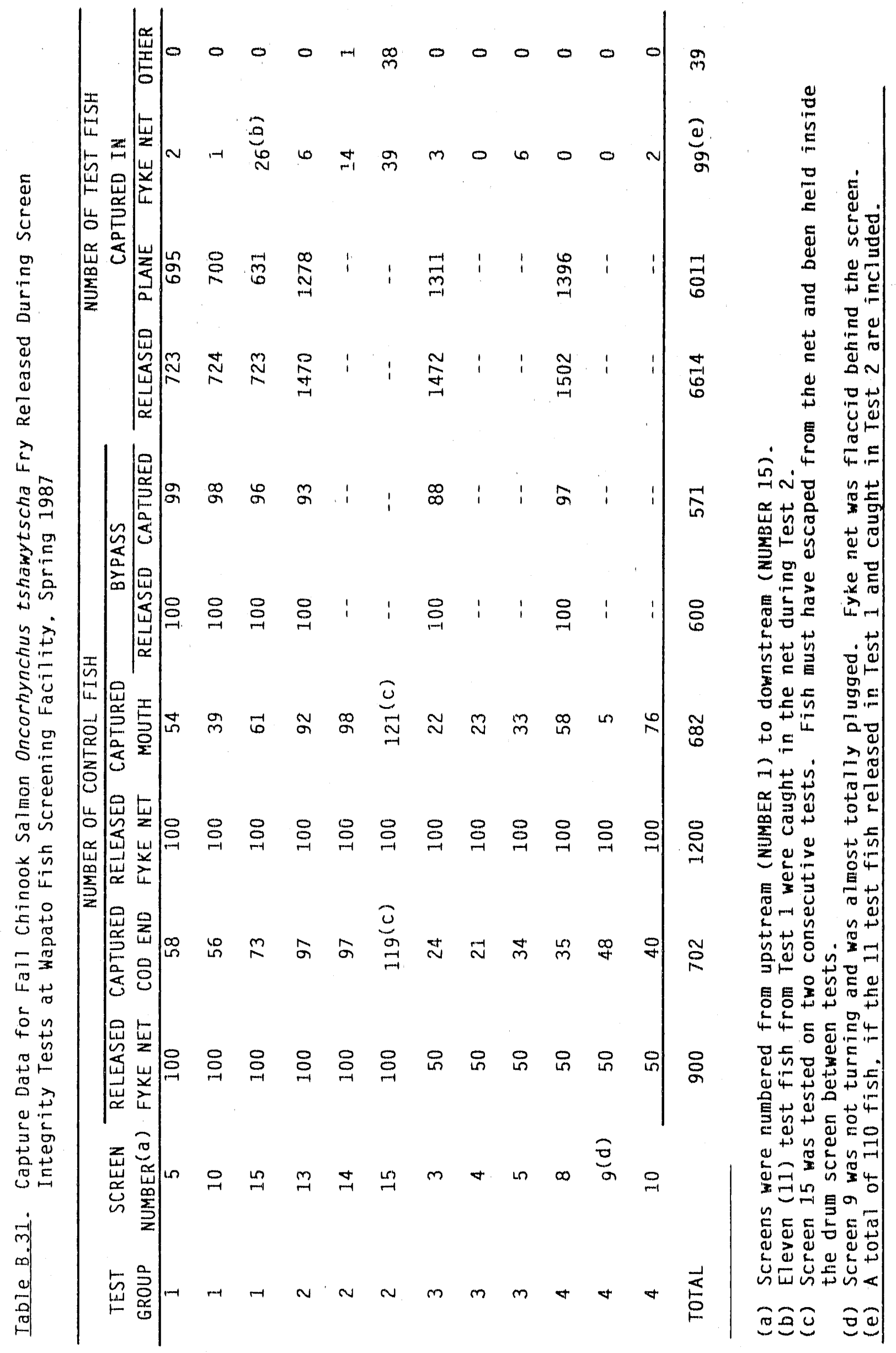




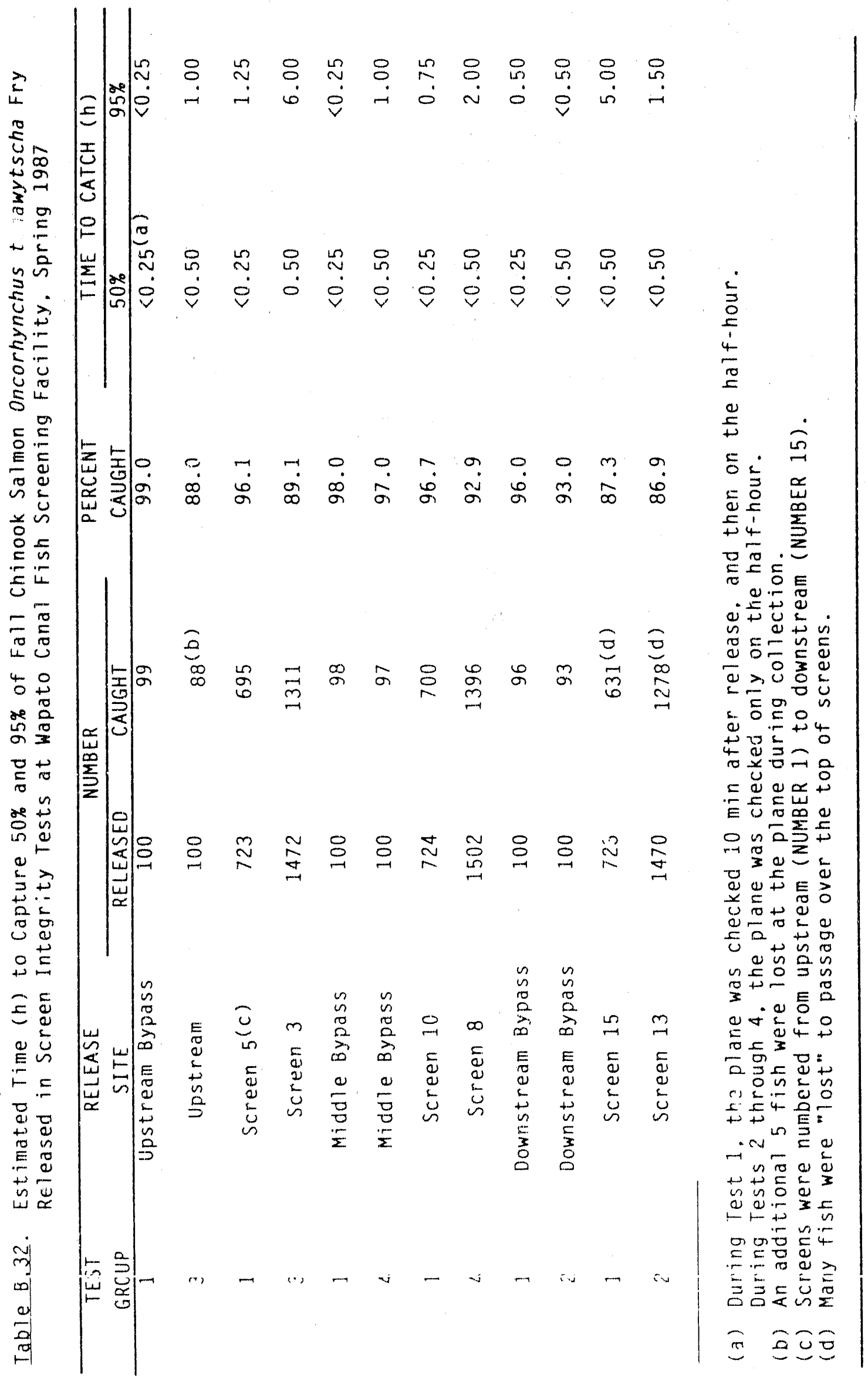


IABLE B.33. Percentage of Steelhead Oncorhynchus mykiss Smolts Descaled or killed in Tests of the Inclined Plane at the Topienish Creek Canal Fish Screening Facility. Spring 1988

\begin{tabular}{|c|c|c|c|c|c|}
\hline \multirow[b]{2}{*}{ REPLICATE } & \multicolumn{3}{|c|}{ NUMBER OF FISH } & \multirow{2}{*}{$\begin{array}{l}\text { PERCENT } \\
\text { DESCALED }\end{array}$} & \multirow{2}{*}{$\begin{array}{c}95 \% \\
\text { CONFIDENCE } \\
\text { INTERVAL }\end{array}$} \\
\hline & RELEASED & CAPTURED & DESCALED & & \\
\hline 1 & 10 & 10 & 0 & 0.00 & $0-31$ \\
\hline 2 & 10 & 10 & 0 & 0.00 & $0-31$ \\
\hline 3 & 10 & 10 & 0 & 0.00 & $0-31$ \\
\hline 4 & 10 & 10 & 0 & 0.00 & $0-31$ \\
\hline 5 & 10 & 10 & 0 & 0.00 & $0-31$ \\
\hline 6 & 10 & 10 & 0 & 0.00 & $0-31$ \\
\hline 7 & 10 & 9 & 0 & 0.00 & $0-34$ \\
\hline 8 & 10 & 10 & 0 & 0.00 & $0-31$ \\
\hline 9 & 10 & 10 & 0 & 0.00 & $0-31$ \\
\hline 10 & 10 & 10 & 0 & 0.00 & $0-31$ \\
\hline TOTAL & 100 & 99 & 0 & 0.00 & $0-4$ \\
\hline
\end{tabular}

TABLE B.34. Percentage of Steelhead Oncorhynchus mykiss Smolts Descaled Before Being Used in Tests at the Toppenish Creek Canal Fish Screening Facility. Spring 1988

\begin{tabular}{|c|c|c|c|c|}
\hline & \multicolumn{2}{|c|}{ NUMBER OF FISH } & PERCENT & $\begin{array}{c}95 \% \\
\text { CONFIDENCE }\end{array}$ \\
\hline$\frac{\text { REPLICATE }}{1}$ & $\frac{\text { EXAMINED }}{70}$ & $\frac{\text { DESCALED }}{0}$ & $\frac{\text { DESCALED }}{0.00}$ & $\frac{\text { INTERVAL }}{0-5}$ \\
\hline 2 & 70 & 0 & 0.00 & $0-5$ \\
\hline 3 & 70 & 0 & 0.00 & 0.5 \\
\hline TOTAL & 210 & 0 & 0.00 & $0-2$ \\
\hline
\end{tabular}


IABLE B.35. Descaling and Mortality Data from Release and Capture Tests with Steelhead Oncorhynchus mykiss Smolts at the Toppenish Creek Fish Screening Facility. Spring 1988

\begin{tabular}{|c|c|c|c|c|c|c|c|}
\hline \multirow{2}{*}{$\begin{array}{l}\text { CANAL } \\
\text { FLOW } \\
\text { (CFS) }\end{array}$} & \multicolumn{4}{|c|}{ NUMBER } & \multicolumn{2}{|c|}{ PERCENT } & \multirow{2}{*}{$\begin{array}{c}95 \% \\
\text { CONFIDENCE } \\
\text { INTERVAL }\end{array}$} \\
\hline & RELEASED & CAPTURED & DESCALED & DEAD & CAPTURED & DESCALED & \\
\hline $\begin{array}{l}20 \\
50 \\
50 \\
\end{array}$ & $\begin{array}{l}250 \\
255 \\
250 \\
\end{array}$ & $\begin{array}{l}144 \\
199 \\
196 \\
\end{array}$ & $\begin{array}{l}0 \\
1 \\
0 \\
\end{array}$ & $\begin{array}{l}0 \\
0 \\
0 \\
\end{array}$ & $\begin{array}{l}57.6 \\
78.0 \\
78.4 \\
\end{array}$ & $\begin{array}{l}0.00 \\
0.50 \\
0.00 \\
\end{array}$ & $\begin{array}{l}0-2 \\
0-3 \\
0-2 \\
\end{array}$ \\
\hline Tota1 & 755 & 539 & 1 & 0 & 71.4 & 0.19 & $0-1$ \\
\hline Wild & & 462 & 1 & 0 & $=$ & 0.22 & $0-1$ \\
\hline
\end{tabular}

IABLE B.36. Estimated Time to Capture $50 \%$ of Steelhead Oncorhynchus mykiss Smolts Released in Descaling Tests at Toppenish Creek Fish Screeiling Facility. Spring 1988

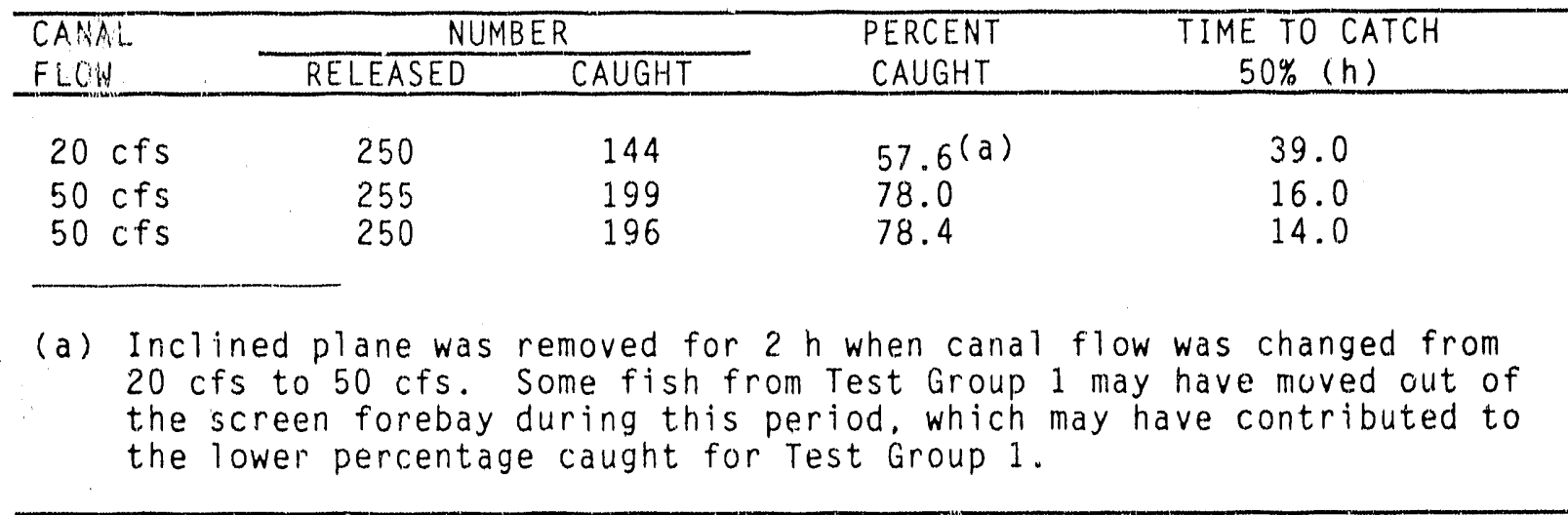

TABLE B.37. Estimated Time to Capture 50\% of Rainbow Trout Oncorhynchus mykiss Fry Released in Screen Intecrity Tests at Toppenish Creek Fish Screening Facility. Spring 1988

\begin{tabular}{ccccc}
\hline TEST & \multicolumn{2}{c}{ NUMBER } & PERCENT & TIME TO CATCH \\
GROUP & RELEASED & CAUGHT & CAUGHT & $50 \%(\mathrm{~h})$ \\
\hline & & & & \\
1 & 1024 & 868 & 84.8 & 4.0 \\
2 & 1024 & 724 & 70.7 & 9.0 \\
3 & 1025 & 781 & 76.2 & 4.0 \\
\hline
\end{tabular}


IABLE B.38. Percentage of Steelhead Oncorhynchus mykiss Smolts Descaled In Pipe Tests at the Toppenish Creek Fish Screening Facility. Spring 1988

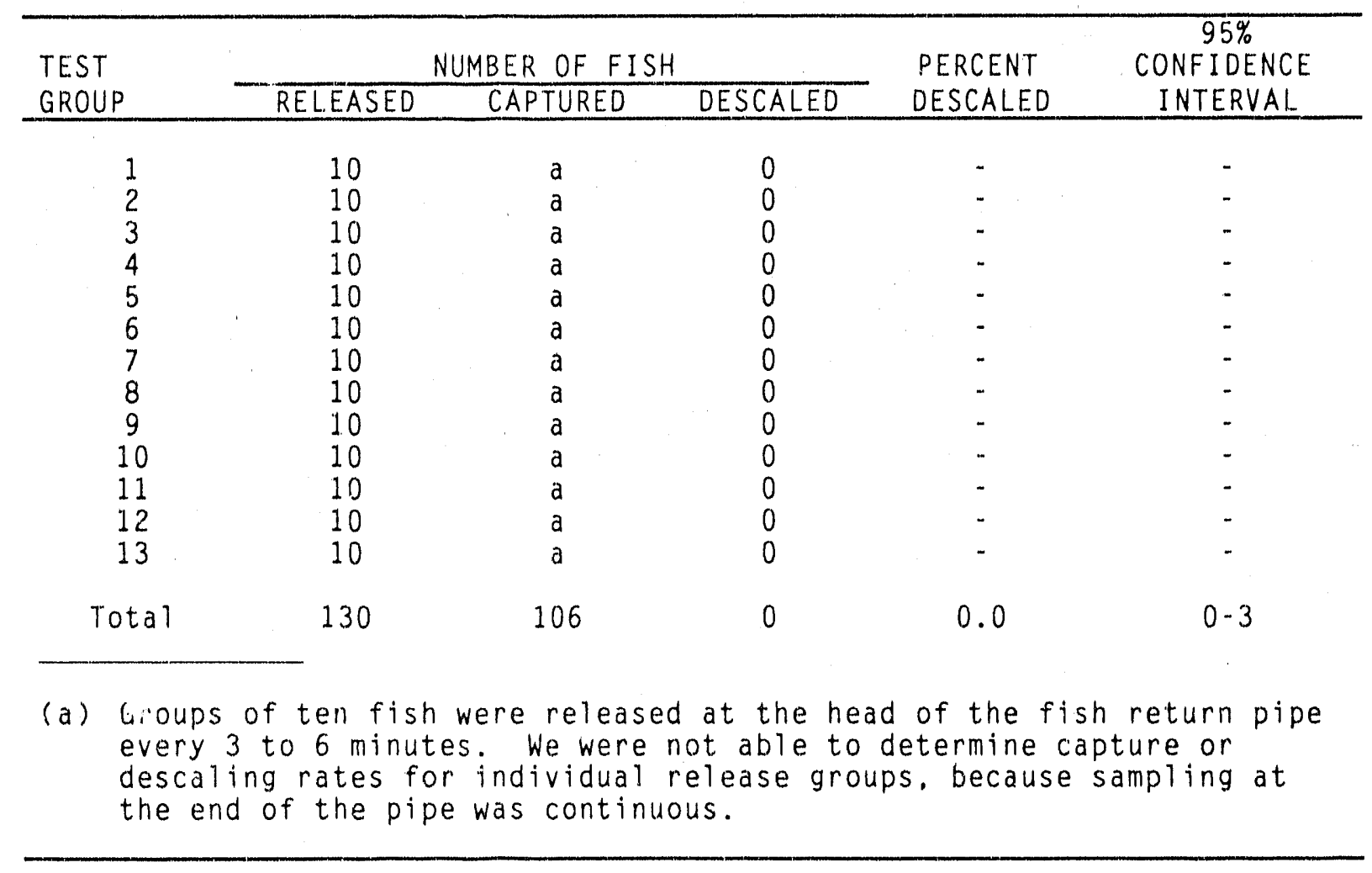




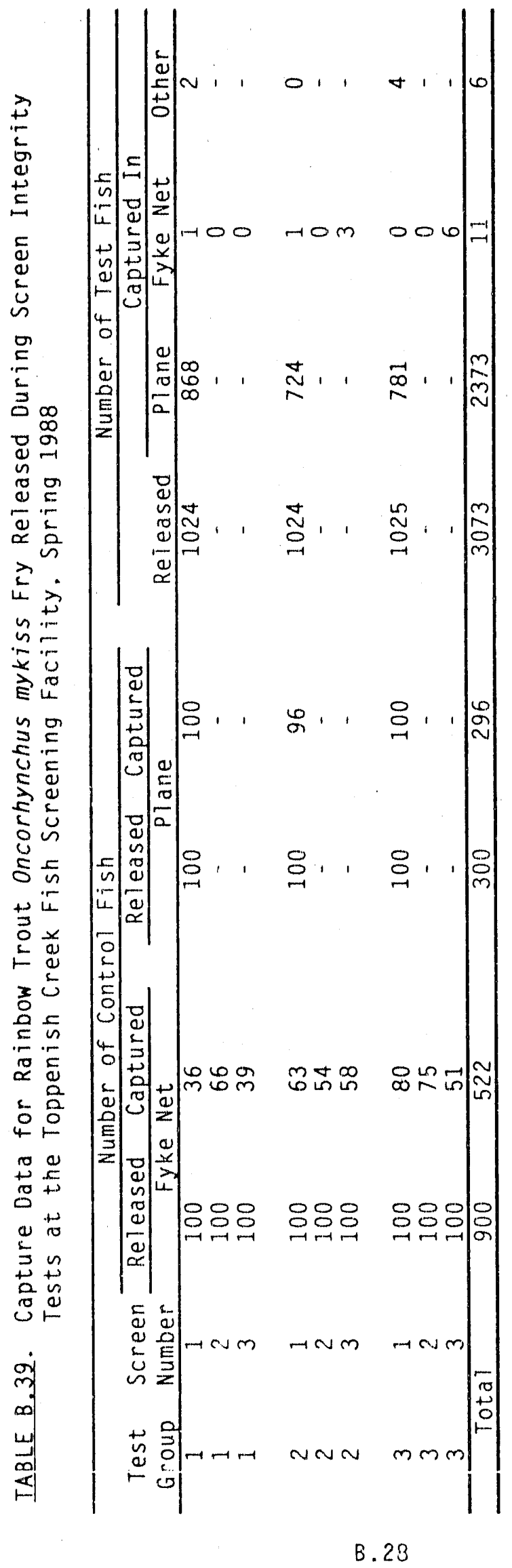


IABLE B.40. Capture Efficiency of the Inclinded Plane and Fyke Nets Used During Screen Integrity Tests at the Toppenish Creek Fish Screening Facility. Spring 1988

\begin{tabular}{|c|c|c|c|c|}
\hline SCREEN & $\begin{array}{l}\text { CA UURE PROBA } \\
\text { INCLINEO PLANE }\end{array}$ & $\begin{array}{l}\text { ESTIMATE } \\
\text { FYKE NET }\end{array}$ & $\begin{array}{c}\text { SCREEN } \\
\text { EFFICIENCY } \\
\end{array}$ & $\begin{array}{c}95 \% \\
\text { CONFIDENCE } \\
\text { INTERVAL } \\
\end{array}$ \\
\hline $\begin{array}{l}1 \\
2 \\
3 \\
a\end{array}$ & $\begin{array}{l}0.987 \\
0.987 \\
0.987 \\
0.966\end{array}$ & $\begin{array}{l}0.597 \\
0.650 \\
0.493 \\
0.580\end{array}$ & $\begin{array}{l}0.999 \\
1.000 \\
0.99^{\prime} \\
0.966\end{array}$ & $\begin{array}{l}1.00-1.00 \\
1.00-1.00 \\
1.00-1.00 \\
0.95-0.98\end{array}$ \\
\hline A) 1 Screens & 0.987 & 0.580 & 0.991 & $0.99-1.00$ \\
\hline
\end{tabular}

(a) During the tests, 37 control fish placed in the fyke nets were caught on the inclined plane. Assuming the $37 \mathrm{fish}$ were test fish that passed from the forebay to the area behind the screens, we calculated a "worst case" screen efficiency of $0.97( \pm 0.015)$.

IABLE B.41. Estimated Time to Capture $50 \%$ of Fall Chinook Salmon Oncorhynchus tshawytscha Fry Released in Screen Integrity Tests at the Wapato Fish Screening Facility, Spring 1988

\begin{tabular}{|c|c|c|c|c|c|}
\hline \multirow{2}{*}{$\begin{array}{l}\text { TEST } \\
\text { GROUP }\end{array}$} & \multirow[b]{2}{*}{ SCREENS } & \multicolumn{2}{|c|}{ NUMBER } & \multirow{2}{*}{$\begin{array}{l}\text { PERCENT } \\
\text { CAUGHT }\end{array}$} & \multirow{2}{*}{$\begin{array}{c}\text { TIME TO CATCH } \\
50 \%(\mathrm{~h})\end{array}$} \\
\hline & & RELEASED & CAUGHT & & \\
\hline $\begin{array}{l}1 \\
1 \\
1 \\
2 \\
3 \\
4\end{array}$ & $\begin{array}{c}5 \\
10 \\
15 \\
13-15 \\
3-5 \\
15\end{array}$ & $\begin{array}{l}1044 \\
1041 \\
1042 \\
1041 \\
1028 \\
1039\end{array}$ & $\begin{array}{l}775 \\
816 \\
535 \\
620 \\
675 \\
959\end{array}$ & $\begin{array}{l}74.2 \\
78.4 \\
51.3 \\
59.6 \\
65.7 \\
92.3\end{array}$ & $\begin{array}{l}6.5 \\
7.0 \\
7.5 \\
4.5 \\
0.5 \\
1.0 \\
\end{array}$ \\
\hline
\end{tabular}




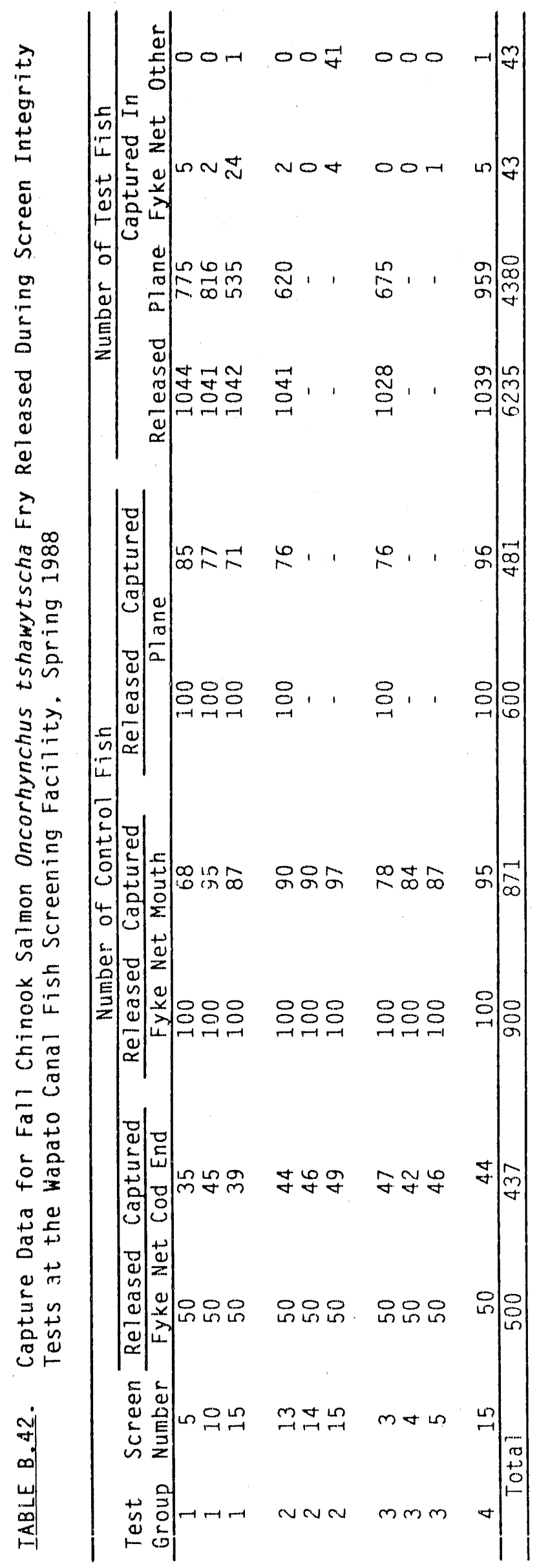


IABLE B.43. Capture Effictency of the Inclined Plane and Nets and Retention Efficiency for Fyke Nets Used During Screen Integrity. Tests at the Wapato Canal Fish Screening Facility. Spring 1988

\begin{tabular}{|c|c|c|c|c|c|}
\hline \multirow[b]{2}{*}{$\begin{array}{l}\text { SCREEN } \\
\text { SECTIION (a) }\end{array}$} & \multicolumn{3}{|c|}{ PROBABILITY ESTIMATE } & \multirow[b]{2}{*}{$\begin{array}{c}\text { SCREEN } \\
\text { EFFICIENCY }\end{array}$} & \multirow{2}{*}{$\begin{array}{c}95 \% \\
\text { CONFIDENCE } \\
\text { INTERVAL }\end{array}$} \\
\hline & $\begin{array}{l}\text { PLANE } \\
\text { CAPTURE }\end{array}$ & $\begin{array}{c}\text { NET } \\
\text { CAPTURE }\end{array}$ & $\begin{array}{c}\text { NET } \\
\text { RETENTION }\end{array}$ & & \\
\hline $\begin{array}{c}1-5 \\
6-10 \\
11-15 \\
15 \\
1-15\end{array}$ & $\begin{array}{l}0.805 \\
0.770 \\
0.810 \\
0.960 \\
0.802\end{array}$ & $\begin{array}{l}0.793 \\
0.950 \\
0.918 \\
0.950 \\
0.968\end{array}$ & $\begin{array}{l}0.850 \\
0.900 \\
0.888 \\
0.880 \\
0.874\end{array}$ & $\begin{array}{l}0.995 \\
0.998 \\
0.984 \\
0.994 \\
0.991\end{array}$ & $\begin{array}{l}0.99-1.00 \\
0.99-1.00 \\
0.98-0.99 \\
0.99-1.00 \\
0.99-1.00\end{array}$ \\
\hline
\end{tabular}

(a) The screens are numbered from the upstream (NUMBER 1) to downstream screen nearest the separation chamber (NUMBER 15).

IABLE B.44. Capture Data from Fyke Nets Behind Selected Screens at the Wapato Canal Fish Screening Facility After the Release of Yakima Indian Nation Fall Chinook Salmon Oncorhynchus tshawytscha from Net Pens in the Wapato Screen Forebay. Spring 1988

\begin{tabular}{lccc}
\hline & & & FYKE NET CAPTURES \\
\cline { 2 - 4 } SCREEN & NET $(a)$ & YIN FISH & OTHER SALMONIDS \\
\hline & $A$ & $(b)$ & $(b)$ \\
13 & $B$ & 1 & 0 \\
14 & $A$ & 1 & 0 \\
14 & $B$ & 3 & 1 \\
15 & $A$ & 148 & 1 \\
15 & $B$ & 190 & 4 \\
\hline \multirow{2}{*}{ Total } & & \\
& & \\
(a) Net "A" mounted in upstream half of the screen; Net B mounted in the \\
(b) Cownstream half of the screen bay.
\end{tabular}


IABLE B. 45. Estimated Time to Capture 50\% of Fall Chinook Oncorhynchus tshawytscha Fry Released in Screen Integrtty Tests at the Sunnyside Fish Screening Factlity. Spring 1988

\begin{tabular}{lcccc}
\hline TEST & \multicolumn{2}{c}{ NUMBER } & PERCENT & TIME TO CATCH \\
GROUP & RELEASED & CAUGHT & CAUGHT & $50 \%(h)$ \\
\hline & 1045 & 746 & 71.4 & 1.0 \\
1 & 1047 & 791 & 75.5 & 1.0 \\
2 & 1047 & 891 & 85.1 & $<0.5$ \\
3 & 1047 & 845 & 80.7 & $<0.5$ \\
\hline
\end{tabular}




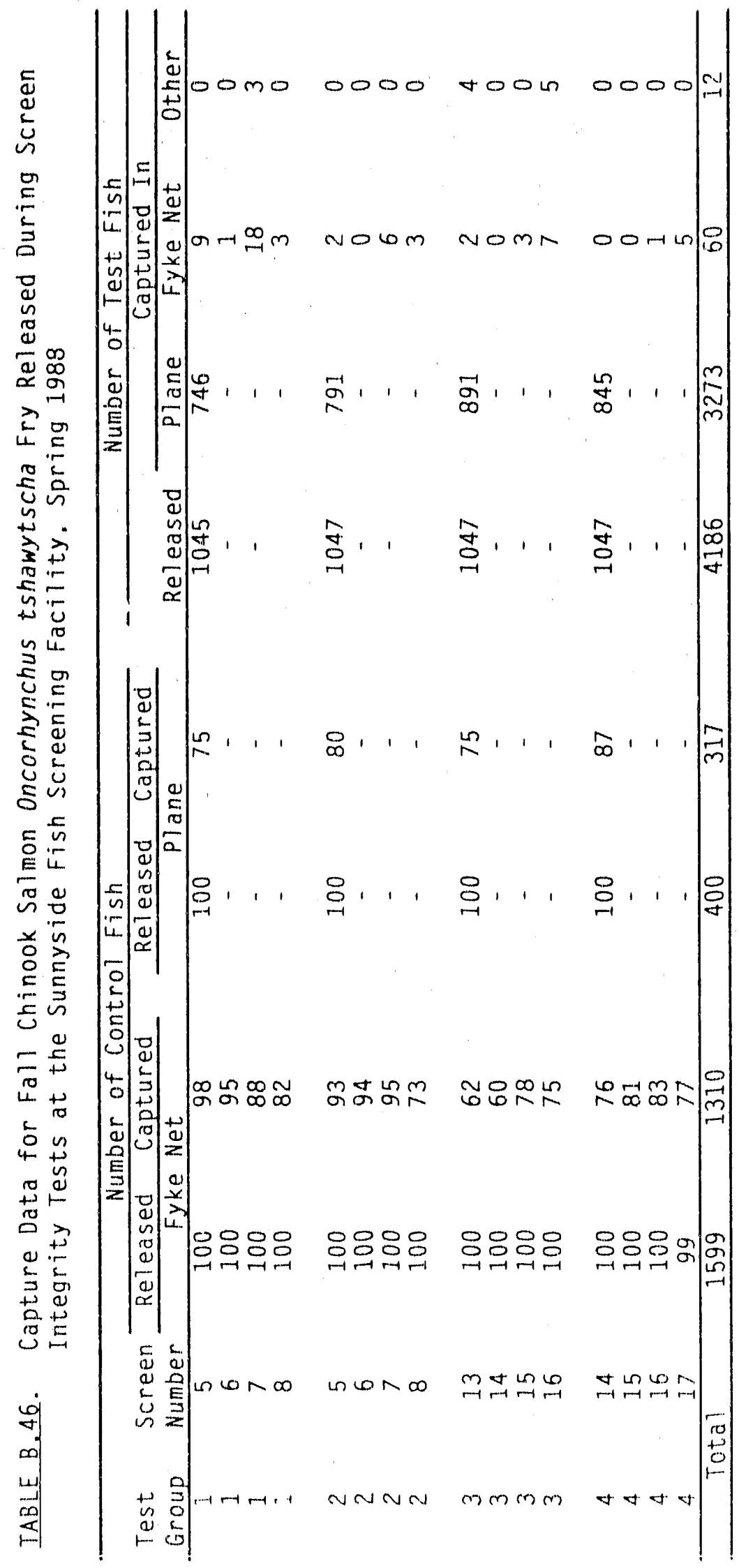


IABLEB.47. Capture Efflctency of the Inclined Plane and Fyke Nets Used During Screen Integrity Tests at the Sunnyside Camal Fish Screenting Factlity, Spring 1988

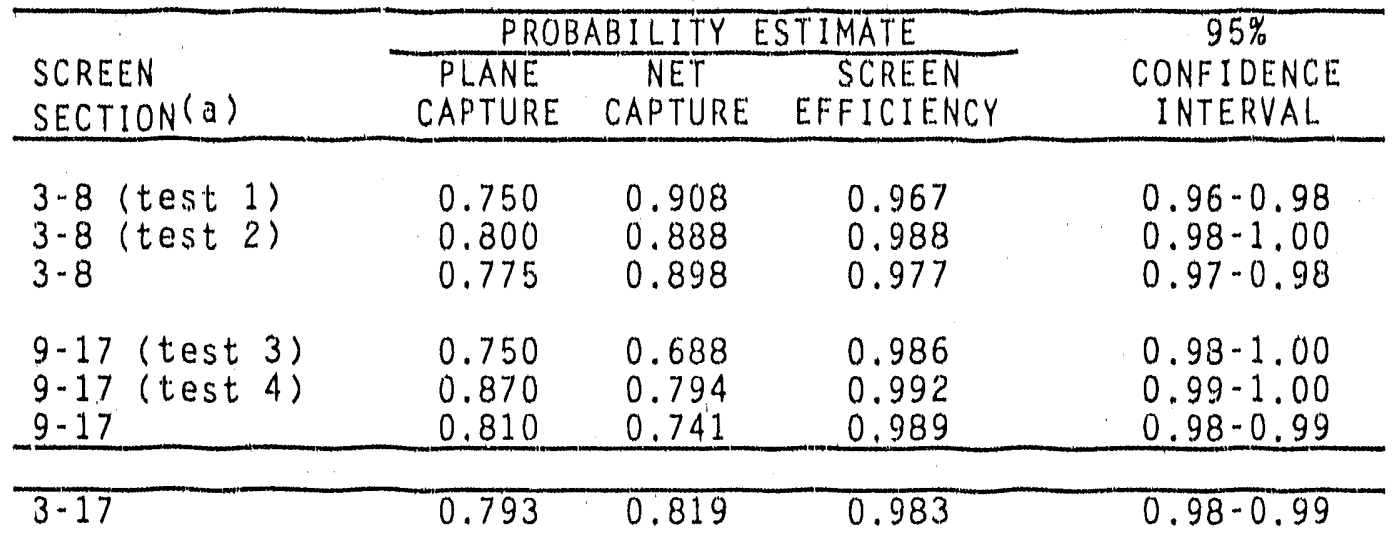

(a) Screens are numbered from the upstream (NUMBER 1) to the downstream screen nearest the separation chamber (NUMBER 17). screens 1 and 2 are permanently out of service.

1 BLE B.48. Capture Data From Fyke Nets Behind Selected Screens at the Sunnyside Canal Fish Screening Facility After the Release of Yakima Indian Nation Fall Chirook Salmon Oncorhynchus tshawytscha Fingerlings From the Wapato Screens Forebay, Spring 1988

\begin{tabular}{cccc}
\hline SCREEN & & \multicolumn{2}{c}{ FYKE NET CAPTURES } \\
\cline { 3 - 4 } NUMBER & NET (a) & YIN FISH & OTHER SALMONIDS $(b)$ \\
\hline 8 & A & 2 & 2 \\
8 & $B$ & 0 & 0 \\
17 & $A$ & 26 & 2 \\
17 & $B$ & 157 & 5 \\
\hline Total & & 185 & 9
\end{tabular}

(a) Net $A$ is the top net. Net $B$ is the bottom net (Figure 7). (b) Includes smolt-sized and o-age salmonids. 


\section{APPENDIX C}

\section{QPERATING SRITERIA FOR THE FISH SCREENING EACILITIES AT SUNNYSIDE. IOPHENISH/SATUS. AND WAPATO CANALS}

Appendix $C$ contains the operating criterta for each of the fish screens that we evaluated during 1988. The criterta were developed by hydrologists from the National Marine Fishertes Service. The intent of the criteria is to provide the information necessary so that maintenance personnel can set and adjust fish bypass flows to achleve optimum fish passage conditions at each screenting facility.

The operating criterla for the Sunnyside screens are on pages C.2-C.11. Text describing different operating modes are on pages C.2-C.5. A diagram of the Sunnyside Screens is on page C.6. Detalled graphs for setting each of the five weirs at the Sunnyside Screens are on pages C.7-C.11.

The operating crtterla for the Wapato Screens are on pages C.12-C.15. Text describing the: operating criterta appears on pages C.12-C.13, and a diagram of the Wapato Screens is on page C.14. A graph summarizing weir crest height adjustiment based on canal surface elevation ts on page C.15.

The operating criterta for the Toppenish Creek Screens are on pages C.16 and C.17. The text describing the operating conditions is on page C.16. A dtagram of the screens is on page C.17. 


\section{Operating Criteria for Sunnyside Canal Fish Screens \\ Bypass system, Trashrack and Screen Structure stoplogs, and Pump Bay Baffles}

\section{Fish Screen Bypass System:}

operation of the fish bypass system requires the adjustment of four bypass overflow weir gates located at points in the bypass system. These weir gates control the quantity of bypass flows and the water surface elevations within the system for good fish passage. The layout of the facility is shown on attached Figure 1.

The operation of the fish bypass requires that 50 cubic feet per second (cfs) enter the pumpback structure through both the intermediate fish bypass pipe and the terminal bypass (100 cfs total). The fish water return pumps, when both are operating, remove $80 \mathrm{cfs}$ from the structure and return it to the Sunnyside Canal downstream of the screen facility. 'The remalning $20 \mathrm{cfs}$ is returned to the river via the primary fish return pipe at the extreme southeast end of the pumpback structure. The bypass system should be operated in the pumpback mode (both pumps operating) whenever river flows past sunnyside Dam are less than 500 cfs to avoid attracting upstream migrating adult fish into the river outlets of the primary and auxiliary fish return pipes.

In lieu of two pump operation, the required cfs bypass flow is provided by proper adjustment of the weir gates. In the case where the pumps are not operating, approximately 50 cfs should exit the structure by each of the primary and auxiliary fish return pipes, returning the total 100 cfs to the river. In the case where only one pump is operating, 40 cfs is pumped back to the canal with approximately 30 cfs being returned to the river by the fish return pipe and auxiliary fish return pipe each making a total of $60 \mathrm{cfs}$ to the river.

To provide these specified bypass flows, the overflow weir gates should be adjusted as follows. The weir gates and gages are numbered and located as shown on the attached Figure 1. 
For Two - Pump operation:

1. Fish return weir gate No. 3 set at e1.891.0 (full open) with yoke at $5.5 \mathrm{ft}$. below deck.

2. Intermediate bypass control weir gate No. 1 at $e 1$. 892.0 (full open), with yoke at $6.0 \mathrm{ft}$. below deck.

3. Terminal bypass weir gate No. 2 set at el. 892.0 (full open), with yoke $4.5 \mathrm{ft}$. below deck.

For No Pumps Operating or one Pump operation:

1. Open all four gates full open

- Fish return weir gate No. 3 set at el. 891.0 with yoke 5.5 ft. below deck.

- Intermediate bypass control weir gate No. 1 set at el. 892.0, with yoke at $6.0 \mathrm{ft}$. below deck.

- Terminal bypass control weir gate No. 2 set at el. 892.0 with yoke at 4.5 ft. below deck.

- Aux fish return weir gate No. 4 set. at el. 892.25 with yoke at $4.25 \mathrm{ft}$. below deck.

Care must be taken to avoid operation of either pump

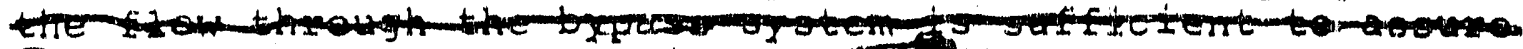
romischarged over weir gate No. 3 through the iish return plpe back to the river. To maintain this minimum return flow all times requires the weir gate No. 3 be lowered completely and the water surface in the pumpback structure at gage No. 4 be at elevation 893.1 or higher. The pump low-water shutoff switches for both pumps must be set at elevations above 893.1 .

Attached figures 2 through 5 provide information on weir gate flows for various gage water surface elevations and weir gate settings, and Figure 6 provides pump discharges for various gage No. 4 water surface elevations. These figures are the basis for the weir gate operations specified above. They can be used to more precisely define flow quantities through the bypass system.

Generally, the weir gate settings specified above will provide the desired bypass system flows during periods when the canal water surface is near the maximum elevation of 896.5. During periods when the canal water surface is 
significantly lower ( below 896.0 ) the bypass flows will fall somewhat short of design values, but biological evaluation of the facility has indicated they will be adequate.

The fabricated metal adjustable-width slot assemblies initially provided for the bypass slots are not to be used.

II. Trashrack Stoplogs:

Wood and steel stoplogs have been provided immediately downstream of the trashracks to alter the naturally unbalanced flow in the canal to obtain a relatively uniform distribution of flow across the full width of the drum screen forebay. This uniform flow is fundamental to obtaining acceptable iish guidance conditions in front of the drum screens. The initial placement of logs was determined by hydraulic model studies and has an eight-foot height of logs in the right (south) bay and a seven-foot height of logs in the center bay. The left (north) bay has no logs placed in it. The placement of the logs should not be changed.

II. Screen Structure stoplogs:

The screen structure stoplogs are located in pier slots immediately downstream of the drum screens. They are wood and steel, to be placed in such a configuration as to prevent floatation. Their purpose is to baffle flow to provide for a uniform velocity distribution through the screen drums.

The stoplog placement has been adjusted based on field observations and velocity measurements to obtain the best flow distribution possible. This placement noted below should be maintained in the future.

Note that "on blocks" means that two concrete blocks are placed beneath the bottom-most log to create a 8 -inch \pm gap between the concrete slab and the bottom log.

Screen

bay No.

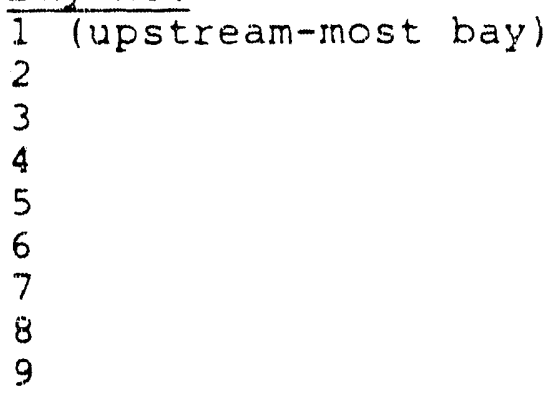

Steel logs/timber logs/

Blocks

Totally closed w/logs

None

None

None

None

None

None

2 steel/3 timber/on blocks None 
10

11

12

13

14

15

16

17 (downstream-most bay)
3 steel/5 timber/on blocks

1 steel/2 timber/on blocks

1 steel/2 timber/on blocks

2 steel/3 timber/on blocks

2 steel/3 timber/on blocks

None

None

None

IV. Pump Bay Baffles:

Directly behind the belt screens in the pumpback structure are structural steel frames with adjustable horizontal

baffles. The baffles regulate the distribution of velocity top to bottom to meet current screening criteria. No future adjustment of the baffles is anticipated. Extra baffles have been provided and are stored on the site. The two frames are different and vary in width by $1 / 2-$ inch to meet "as-build" concrete dimensions. 


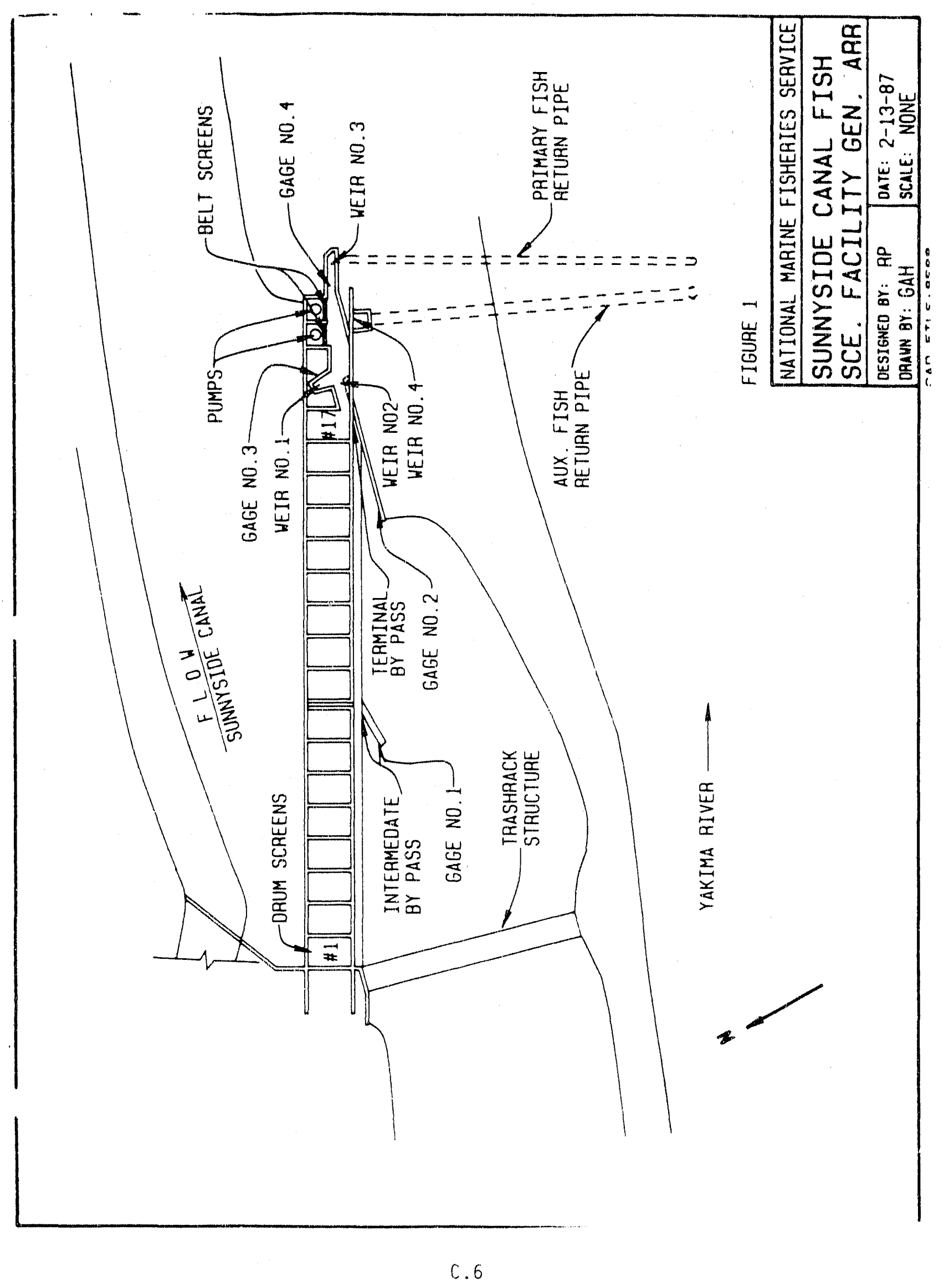




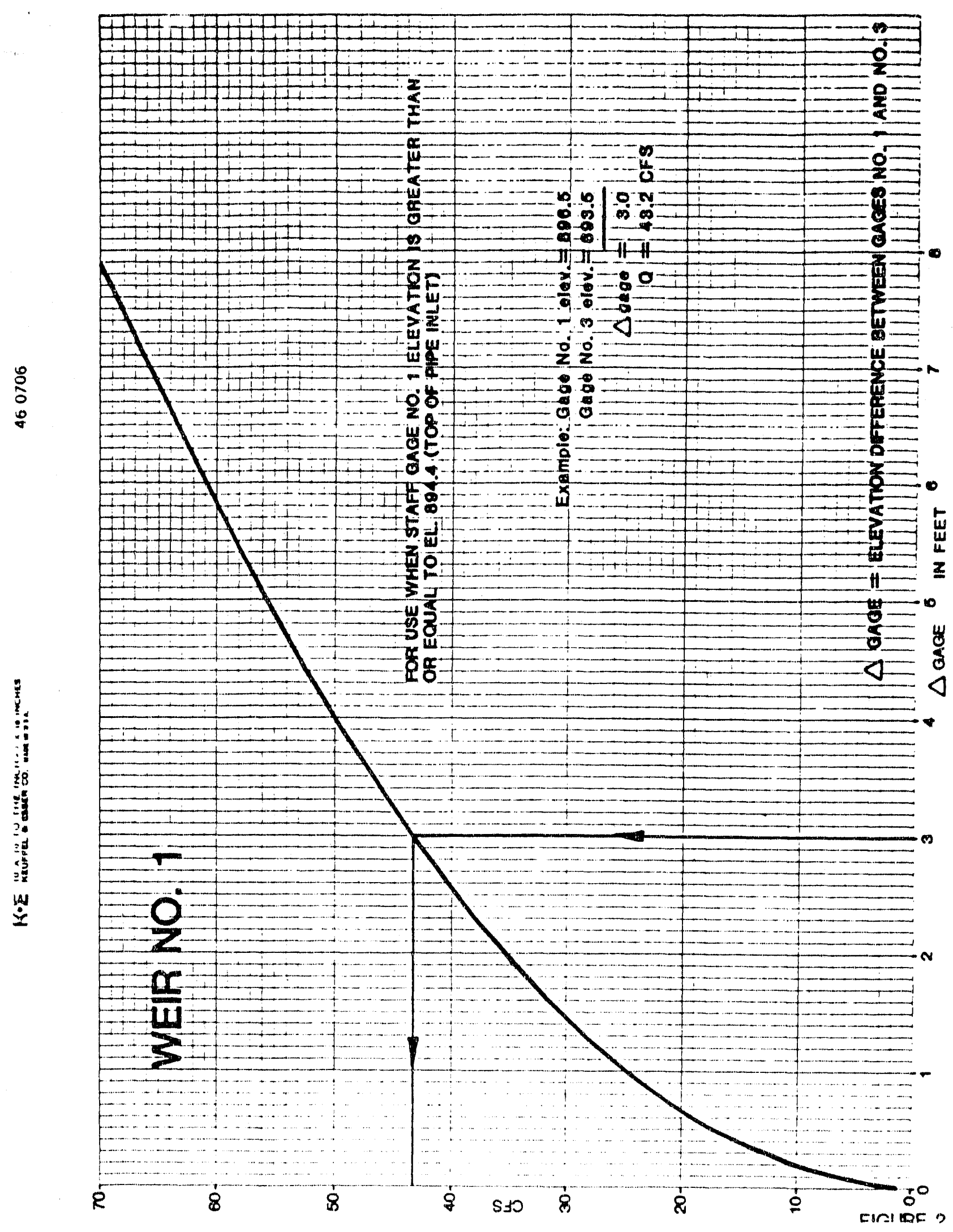




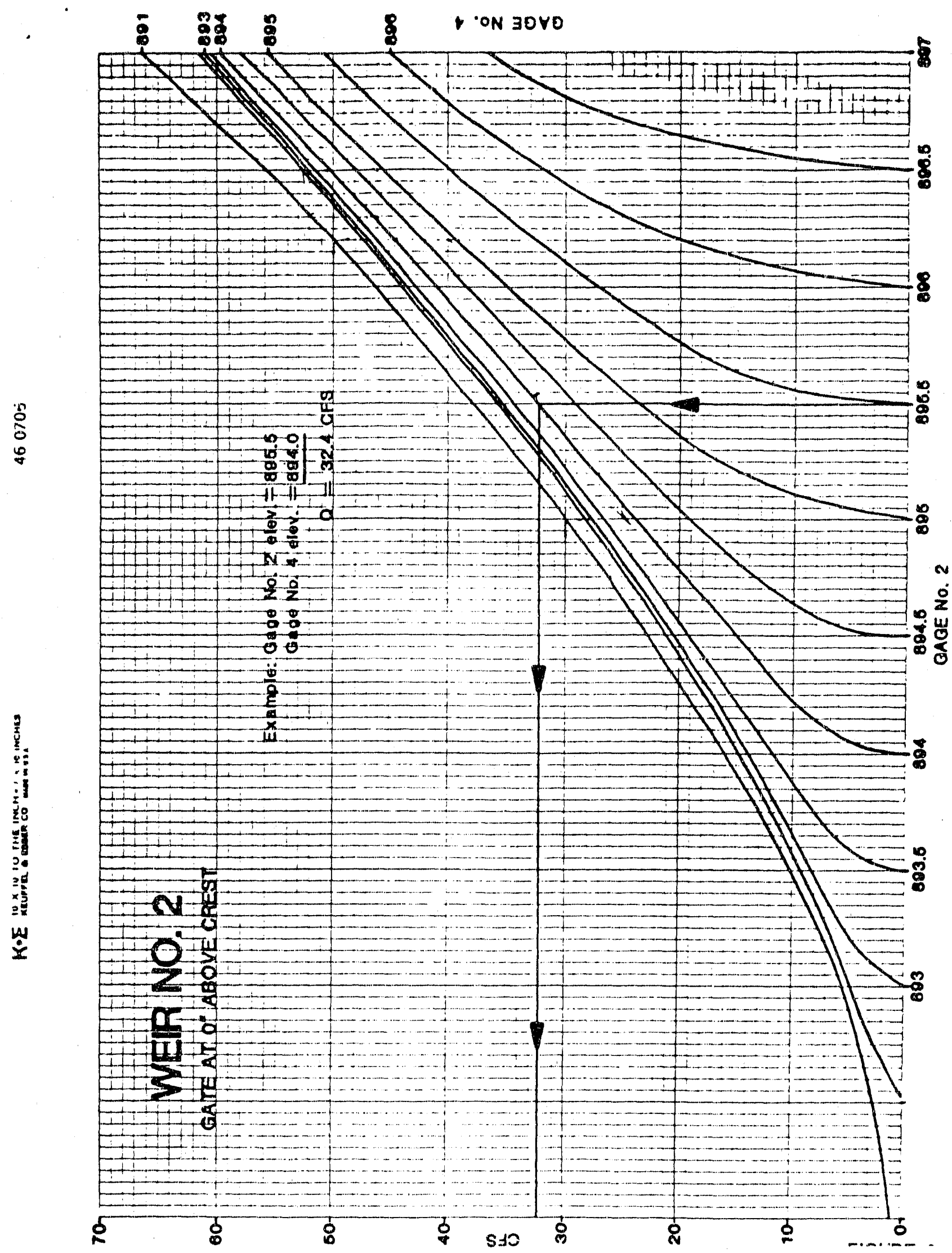

C. 8 


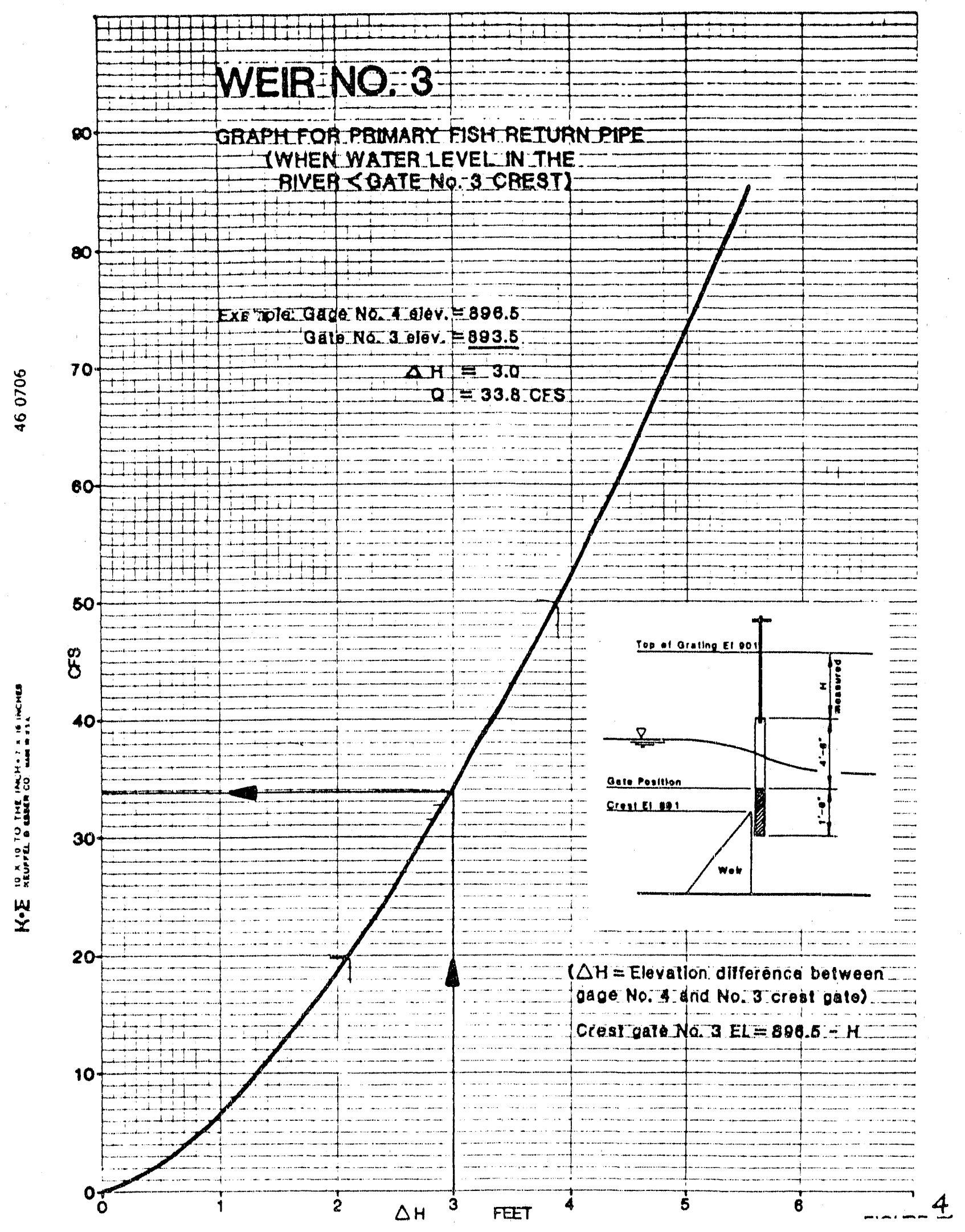




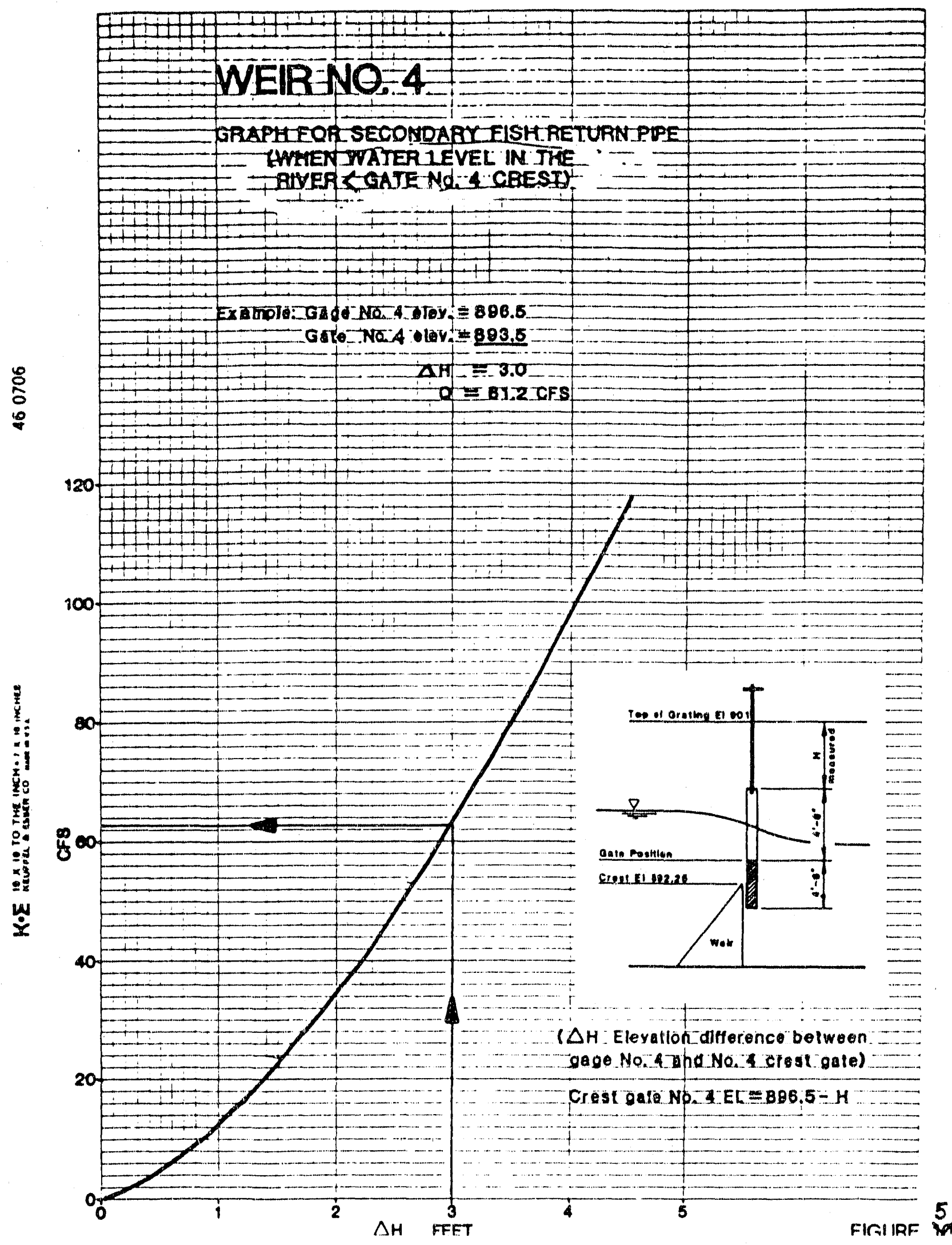

C. 10 


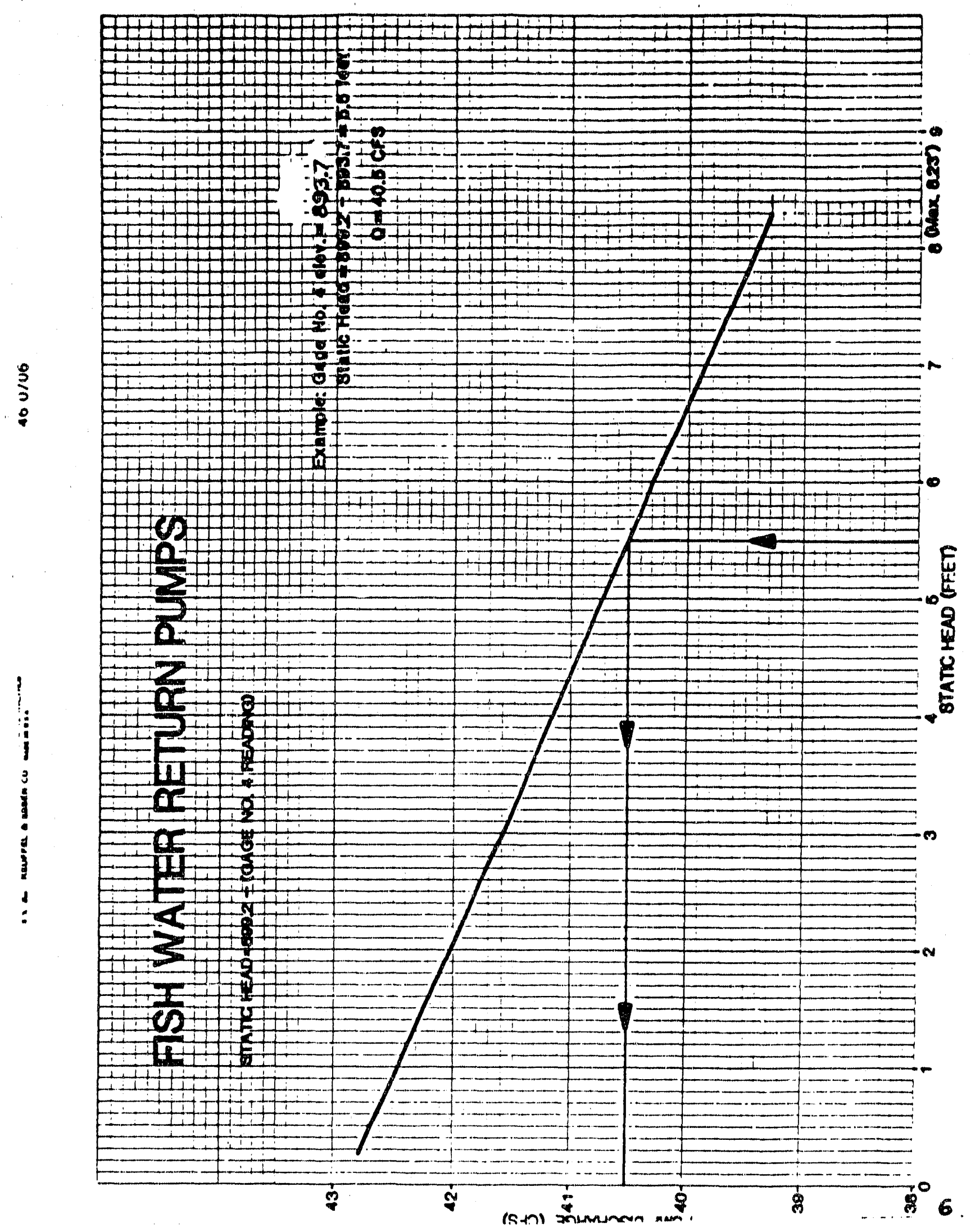

C. 11 
Revised $6 / 29 / 87$

\section{Operating Criteria \\ Napato Canal Fish Screens Bypass System}

Operation of the bypass system requires the adjustment of four 2-foot wide bypass overflow weir gates (these are temporarily stoplogs at the present time) located in the fish bypass channels and two 5-foot wide excess water ovejflow weir gates located behind the pumps in the pumpback structure. These weir gates for temporary stoplogs) control the quantity of bypass flows and the water surface elevations within the system for good fish passage.

Weir gates (or stoplogs) should be adjusted as follows. Weir gate locations are shown on the attached sketch.

Normal Operation (no pumpback):

1. Adjust crest of weir gates \#1, \#2, and \#3 lor top of temporary stoplogs) to appropriate elevation depending on canal w.s. (water surface) elevation from attached graph. Example: canal w.s. in front of drum screens is at elevation 934.0 ; : crest of weir gates (stoplogs) to elevation 930.7

2. Adjust crest of weir gate \#4 (or top of temporary stoplogs) To appropriate elevation depending on canal w.s. elevation as shown on attached graph. Example: canal w.s. elevation 934.0 ; set crest of \#4 weir gate (or top of stoplog) at elevation 928.0 .

3. Adjust weir gates \#5\&\#6 "equally" until w.s. elevation in front of traveling screens is $3.5^{\prime}$ lower than canal w.s. elevation in front of drum screens. Example: canal w.s. elevation 934.0: adjust weir gates \#5 \#6 equally until w.s. elevation is front of traveling screens is 930.5 .

Operation with Pumpback:

1. Set weir gates \#1,\#2, \#3\&\#4 same as for Normal Operation (No Pumpback).

2. With either one or both pumps in operation adjust both weir gates \#5\&\#6 to maintain the traveling screen w.s. 3.5" lower than canal w.s. elevation. Divide flow through both traveling screens equally.

3. If the difference between the canal w.s. and the traveling screen W.S. is greater than $3.5^{\prime}$, even with 
both weir gates \#5\& \#6 closed, then lower gates \#1, \#2 \& 3 equaliy to obtain $3.5^{\prime}$ difference. Note: This 18 very important since for certain conditions the pumps may have enough capacity to pull the water level in the pumpback structure down two low, drying up the bypass flow over weir gate No. 4 and resulting in major fish damage. 


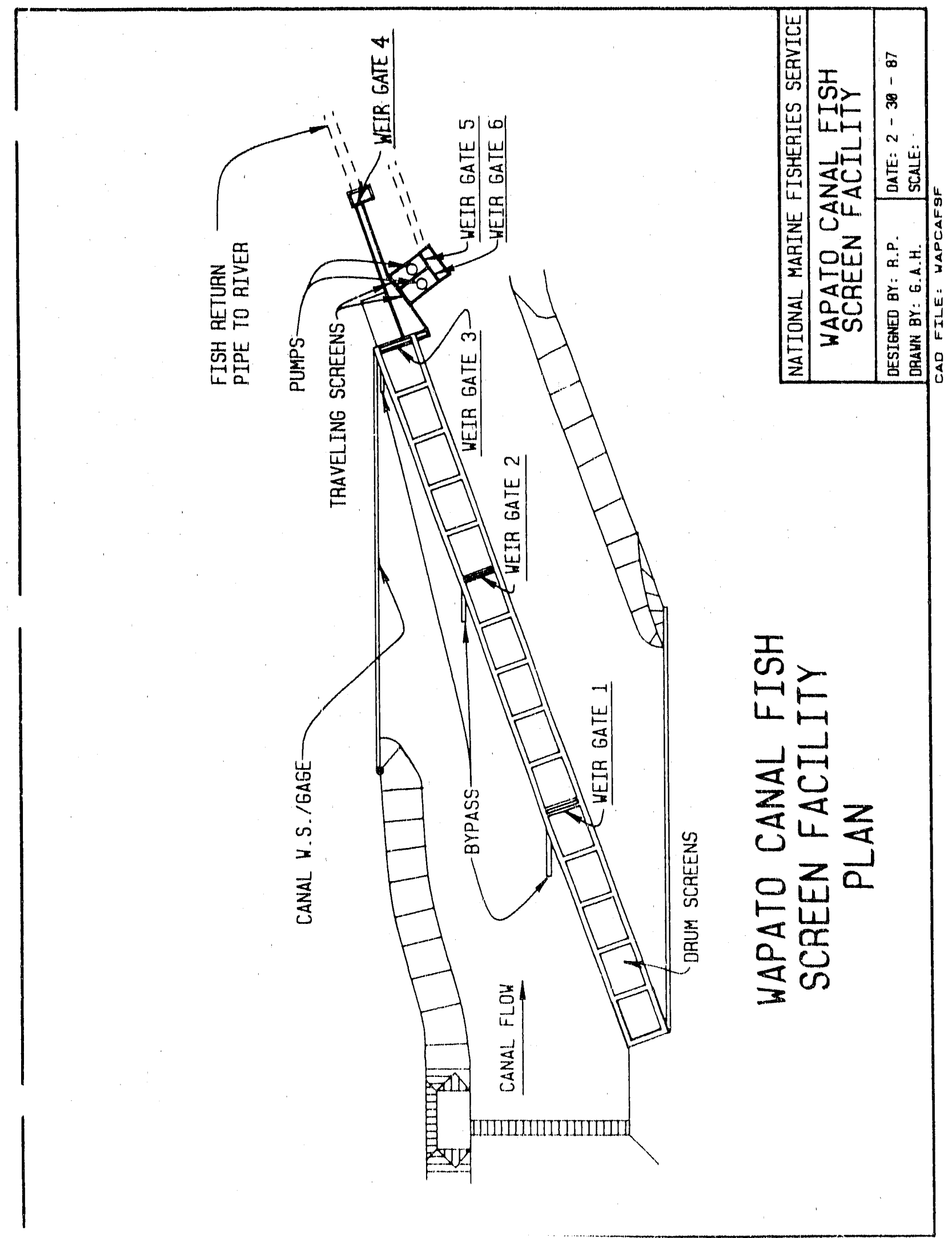




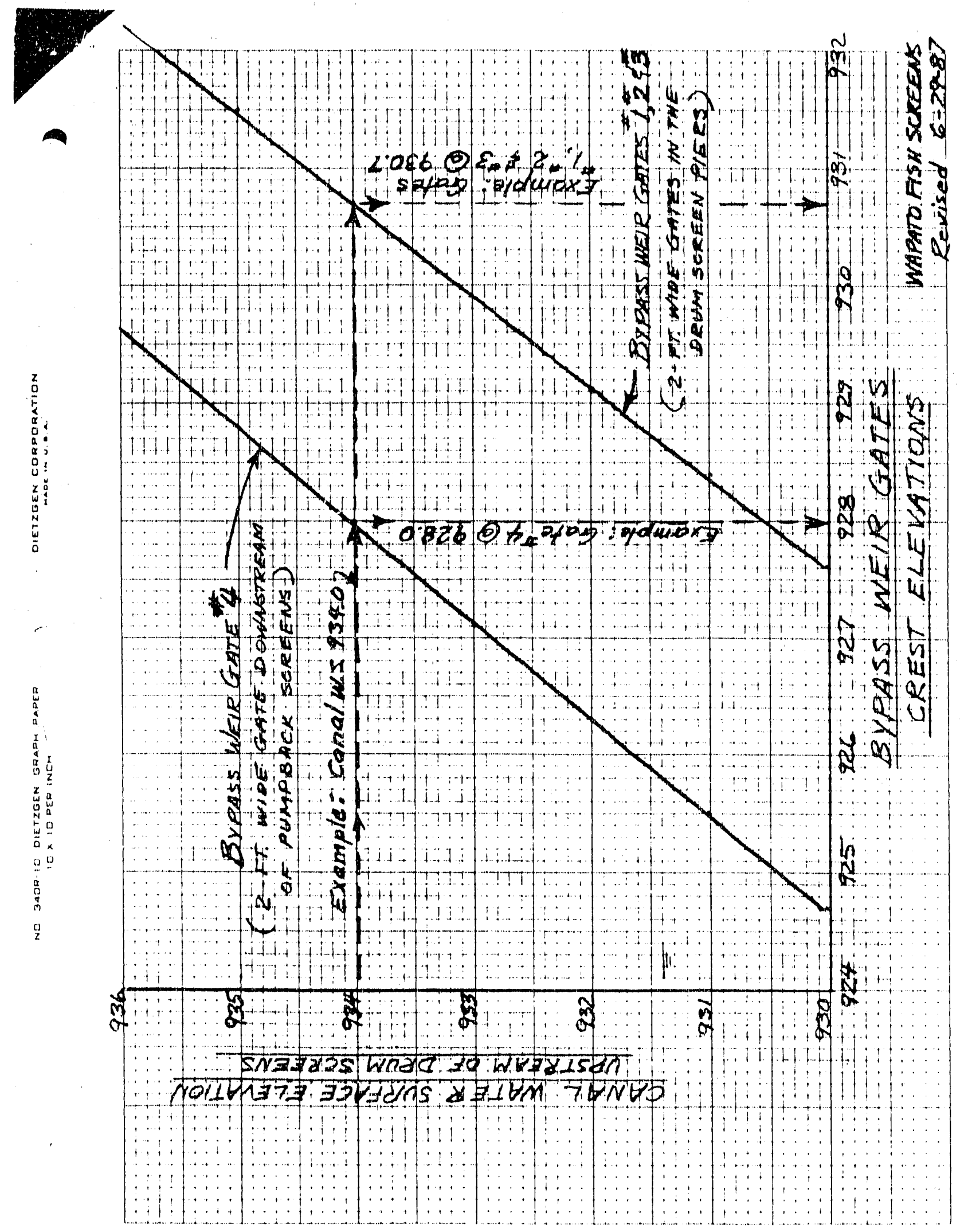


Revised 6-29-87

TOPPENISH CREEK DIVERSION SCREENS OPERATING CRITERIA

1. Normal canal water surface is to be checked up at a location down the canal to operate between elevation 1307.5 and 1308.0 as read on gage No. 1 (see attached sketch). The water surface is not to exceed elevation 1308.2 , to avoid fish being carried over the screen drums.

2. Flow through the bypass slot and fish return pipe is controlled by stoplogs placed in slot $C$ in a manner to form an overflow weir. slots $A$ and $B$ are to be empty.

3. Fish return flow required is 16 cfs when ample flow is available and when adequate head differential exists between the canal 'water surface and the river water surface at the fish return pipe outfall location. To provide at least 16 cfs flow, maintain the crest (top) elevatjon of the stoplogs in slot $C$ at least 1.4 feet lower than the canal water surface at gage No. 2 immediately upstream of slot $B$.

NOTES: When very high flows occur in Toppenish Creek of over 500 cfs the head differential from the canal to the creek at the fish return pipe outfall may not be adequate to provide the full 16 cfs fish return flow.

At very low creek flows when spill over the dam has stopped, the fish return flow may be reduced by addition of stoplogs in slot $C$ to provide flow needed in the canal downstream of the screening facility. If additional stoplogs are inserted it is important that they be removed when creek flows once again increase or canal demand drops, so that full fish return flow is restored. 


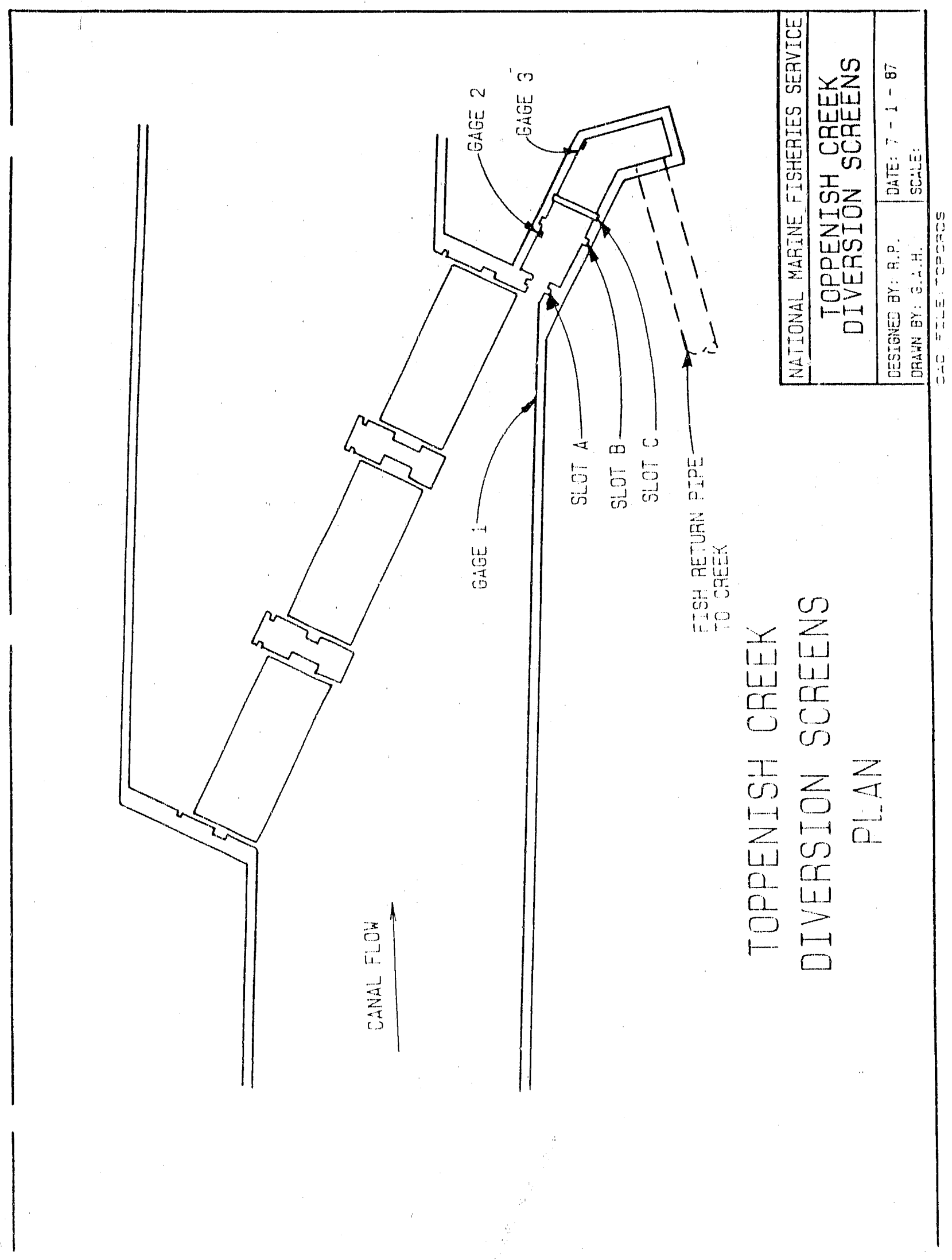



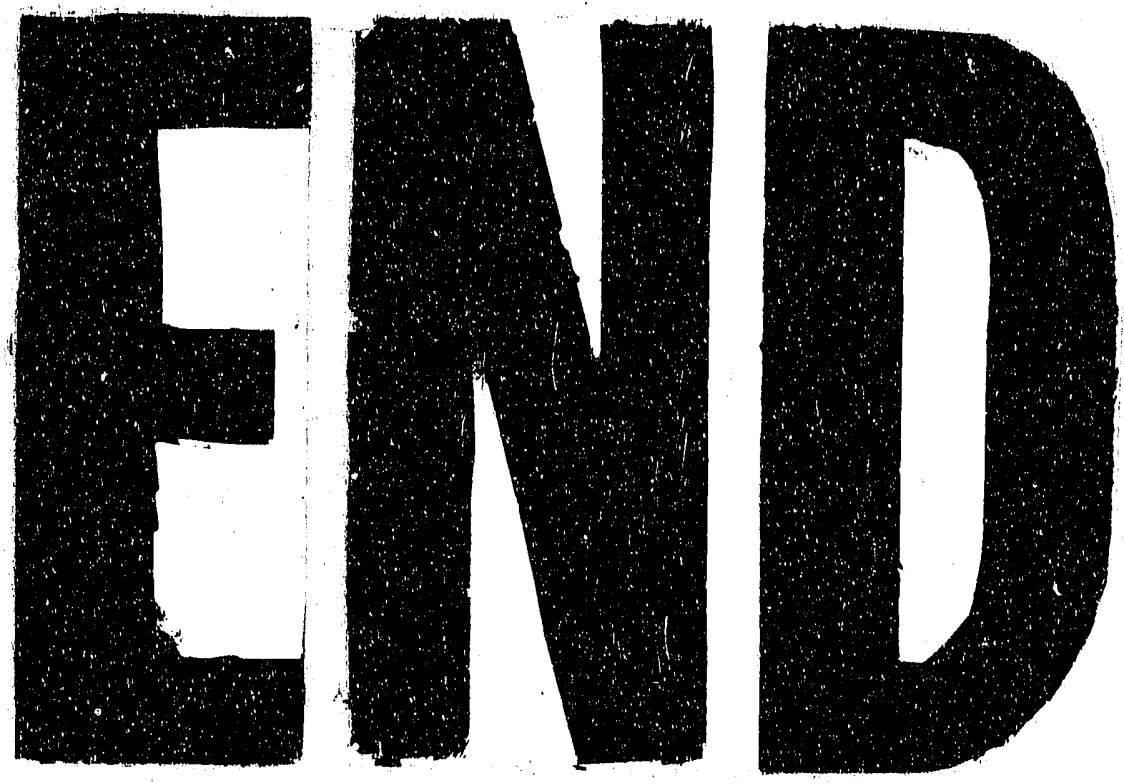

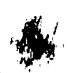
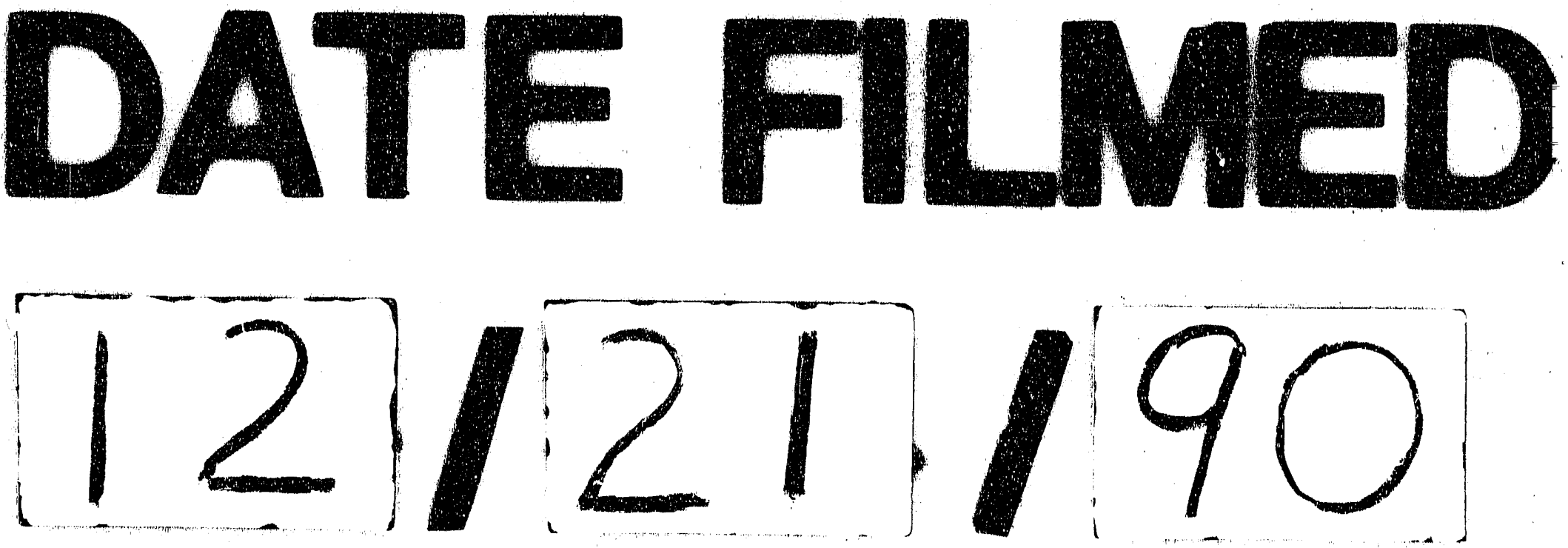
